\title{
Investigation into Nutrient Supplementation for Organic Carbon Removal in Drinking Water Biofilters
}

\author{
A thesis submitted to \\ the Faculty of Graduate and Postdoctoral Affairs \\ in Partial Fulfillment of the requirements for the degree \\ Master of Applied Science in Environmental Engineering \\ by
}

Sahil Dhawan

(B. Eng.)

Department of Civil and Environmental Engineering Carleton University

Ottawa-Carleton Institute of Civil and Environmental Engineering

May 2015

(C)2015 Sahil Dhawan 


\begin{abstract}
Three lab scale dual media columns filtering synthetic raw water were monitored for dissolved organic carbon removal under nutrient limited (nitrogen, phosphorous deficient) and nutrient enhanced (nitrogen, phosphorous supplementation) conditions. The effects of different types of backwash procedures were also observed. Overall, nitrogen and phosphorous enhancement improved DOC removals by $14 \%-18.5 \%$. As well, the addition of air scour to the backwash procedure increased DOC removal by $8 \%$ for the nutrient limited control column. Besides nitrogen and phosphorous, the effects of potassium addition were also studied. Potassium enhancement did not improve DOC removal but an increase in phospholipid biomass values was observed. Following this increase, a biomass sloughing event was observed that may have been a result of the potassium enhancement. No clear correlations could be drawn between biomass phospholipid or ATP values and DOC removal. Final top of the filter biomass values ranged from $7-474 \mathrm{nmol} \mathrm{P} / \mathrm{g}$ media and $0.6 \times 10^{5}-32.74 \times 10^{5} \mathrm{pg} \mathrm{ATP} / \mathrm{g}$ sample for the phospholipid and ATP values respectively.
\end{abstract}




\section{Acknowledgments}

At the outset I would like to thank my supervisor Dr. Onita Basu. Your constant support and guidance has been a source of motivation and helped me strive to achieve the best I could.

I would also like to thank Stanley Conley, Pierre Trudel and Benjamin Griffin from the Civil Engineering laboratory at Carleton University for their help with constructing the columns and setting up the chiller that was used.

I give thanks to Dr. Marie Tudoret for always being present to lend a helping hand and providing helpful advice in the laboratory.

I would also like to thank the various people who helped me along the way. Dejan Chortanoski, Bruna Senna, Miaoyi Yan and Massie Aruiyengho along with everyone in Dr. Basu's research group. You guys rock!

Finally, I want to thank my family. Without your sacrifices and hard work, I would not be where I am today. Thank you to my parents, sister and my grandparents for their love, support and constant encouragement. 


\section{Table of Contents}

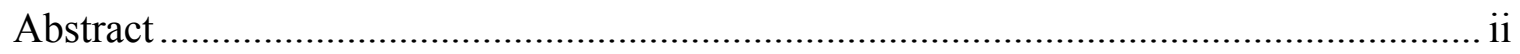

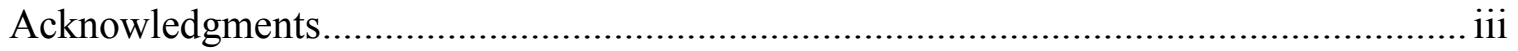

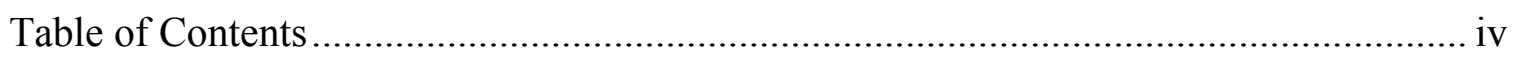

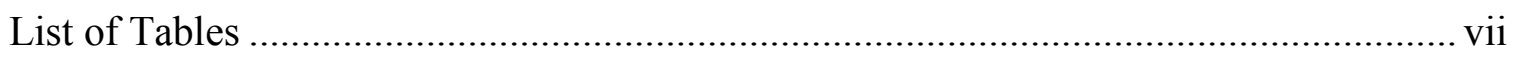

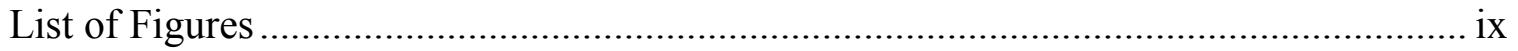

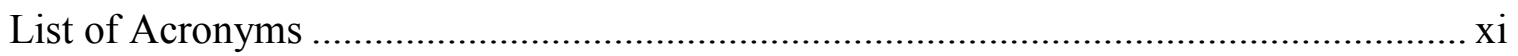

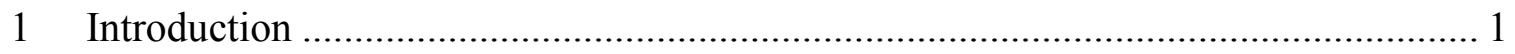

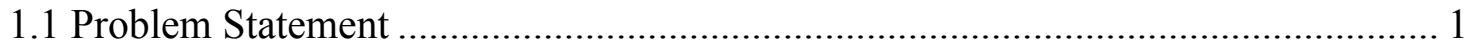

1.2 Research Objectives ..................................................................................... 2

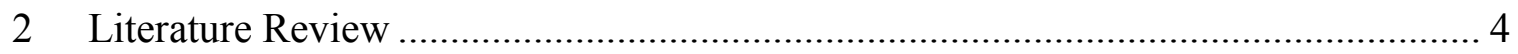

2.1 Biofiltration in Drinking Water Treatment .......................................................... 4

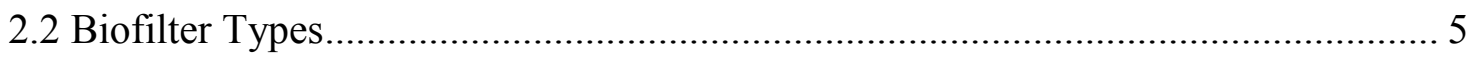

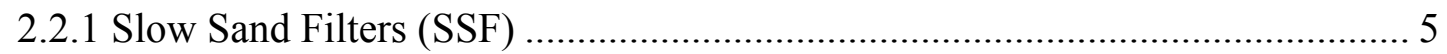

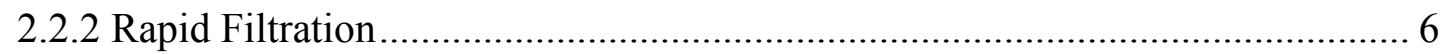

2.3 Biofilter Pre-Treatment .................................................................................. 9

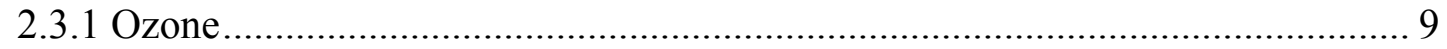

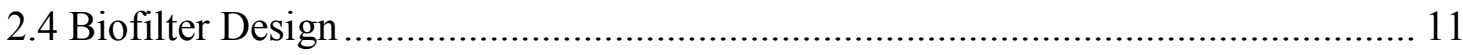

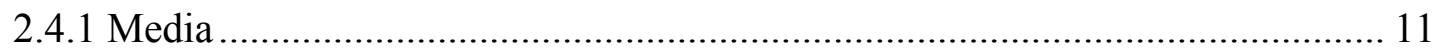

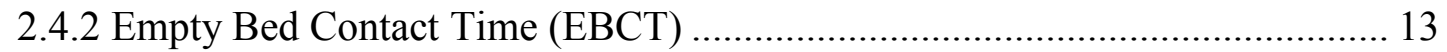

2.4.3 Filter Acclimation and Filter Depth.......................................................... 14

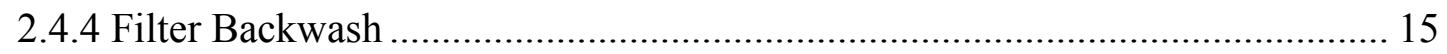

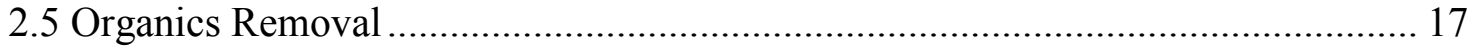

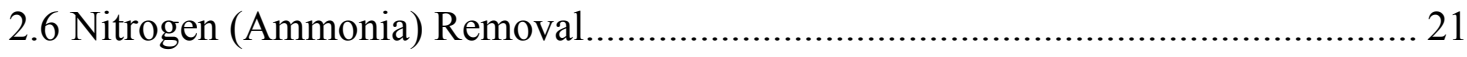

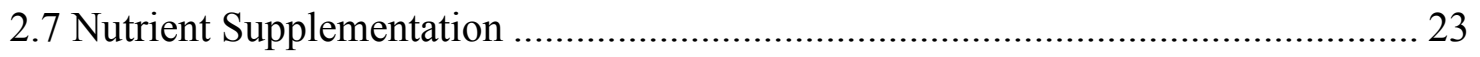

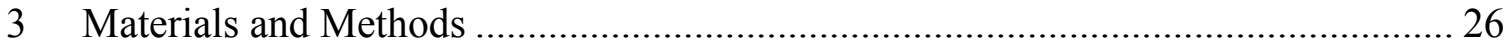

3.1 Pilot Scale Experiments (Preliminary Study Phase) ......................................... 26

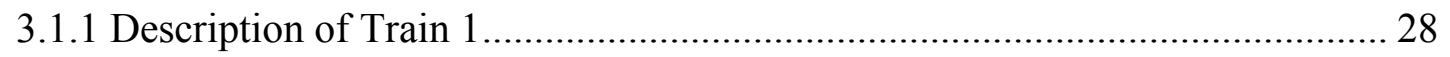

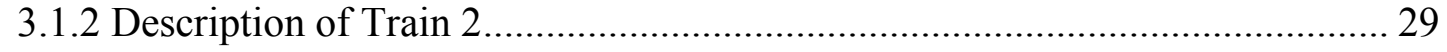

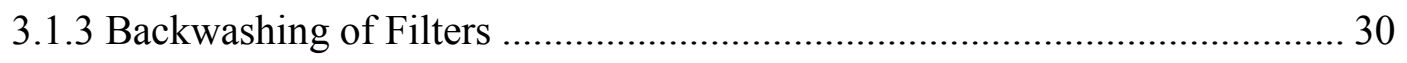

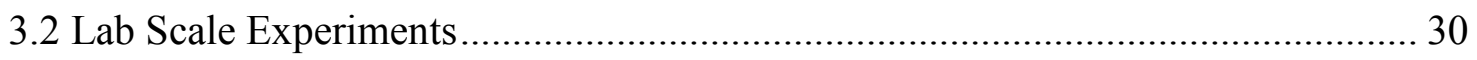




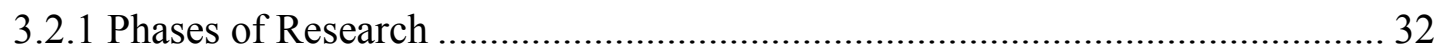

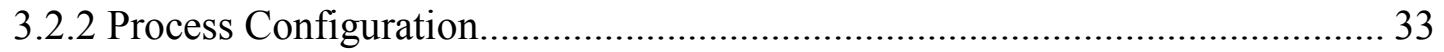

3.2.3 Backwash Procedures .................................................................................... 34

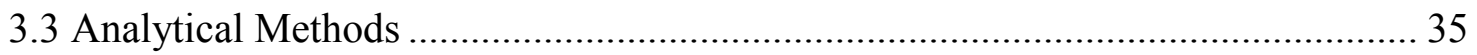

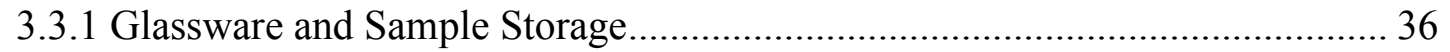

3.3.2 Dosing Solution Preparation (Lab Scale) ………………………………….... 37

3.3.3 Total Organic Carbon (TOC)/Dissolved Organic Carbon (DOC)..................... 37

3.3.4 Ultraviolet Absorbance (UVA) and Specific Ultraviolet Absorbance (SUVA)38

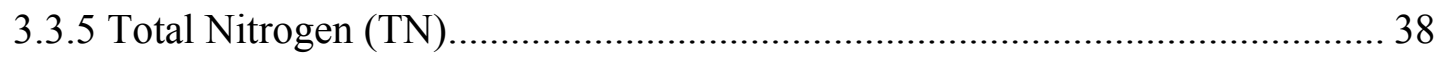

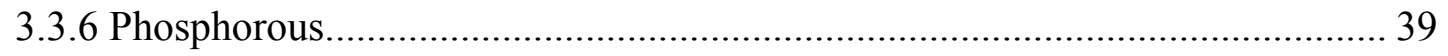

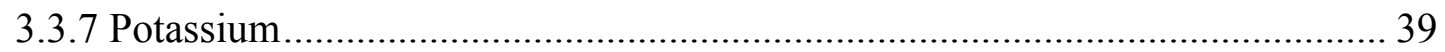

3.3.8 Adenosine Tri-Phosphate (ATP) Method for Biomass Quantification ............ 39

3.3.9 Phospholipid Method for Biomass Quantification ............................................. 40

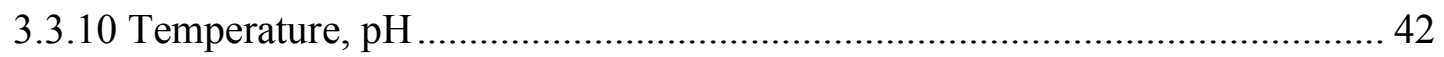

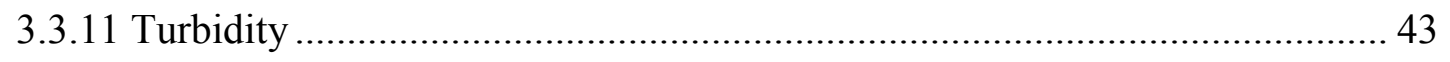

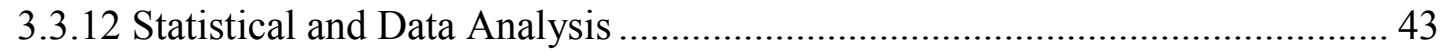

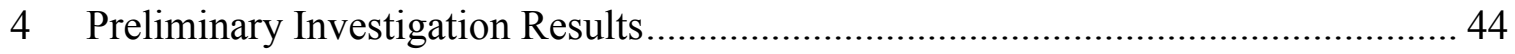

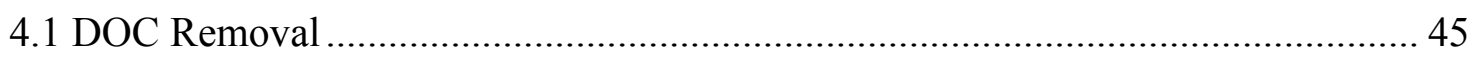

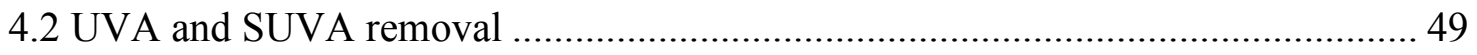

4.3 Relationship between ATP concentrations and DOC removal ................................ 51

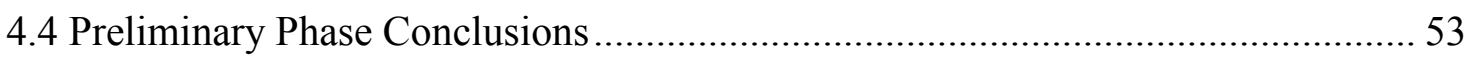

5 Investigation into Nutrient Supplementation to Improve DOC Removal in Drinking

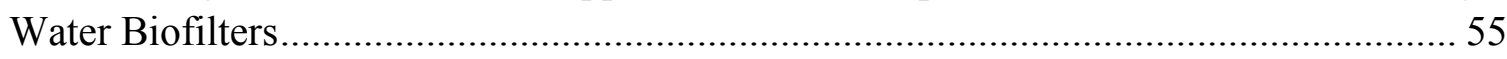

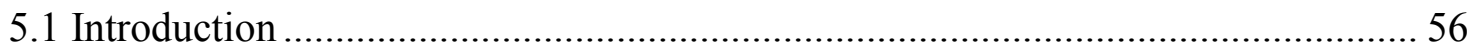

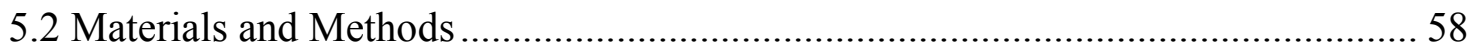

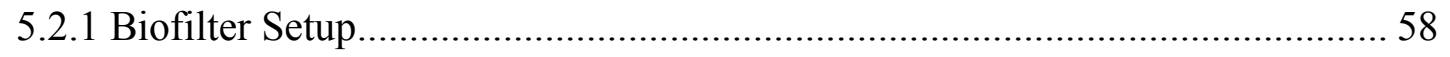

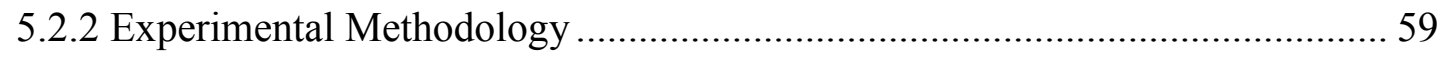

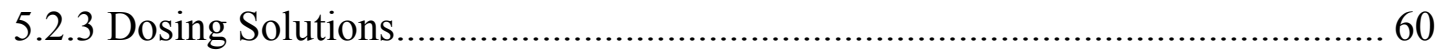

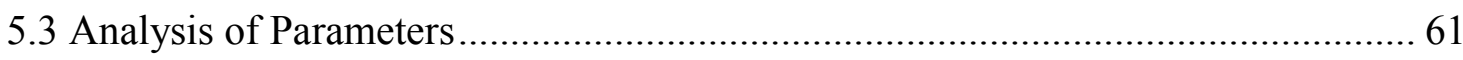

5.3.1 Total Organic Carbon (TOC) and Dissolved Organic Carbon (DOC).............. 61

5.3.2 Ultraviolet Absorbance (UVA) at $254 \mathrm{~nm}$ and SUVA........................................ 61 


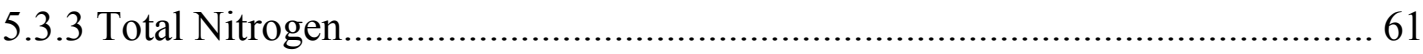

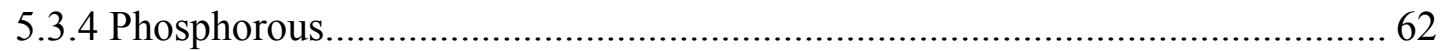

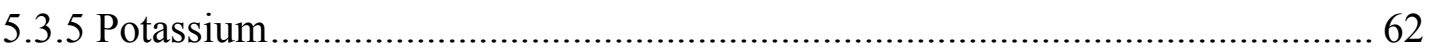

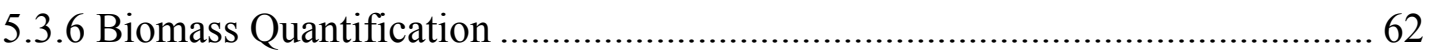

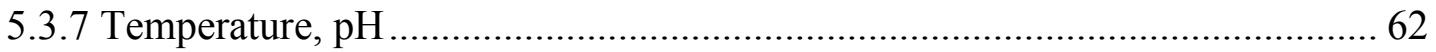

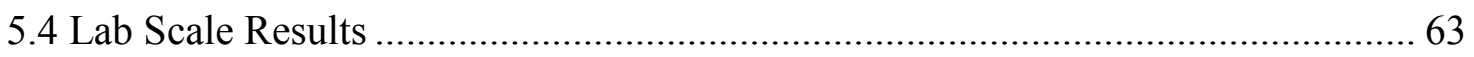

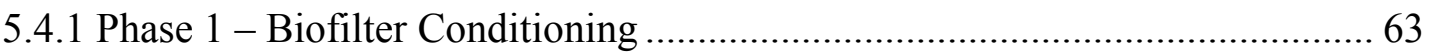

5.4.2 Phase 2 - Impact of Nutrient Supplementation ............................................... 65

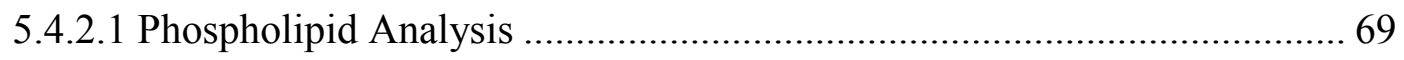

5.4.3 Phase 3 - Impact of Potassium Addition on Biofilter Performance................. 72

5.4.3.1 Total Nitrogen (TN) Removal ............................................................ 76

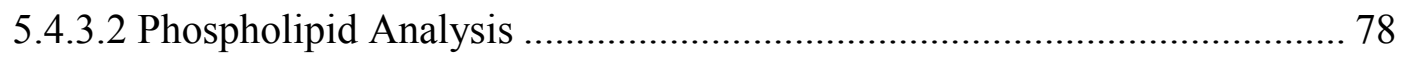

5.4.3.3 Impact of Potassium on Biomass Concentration ........................................ 79

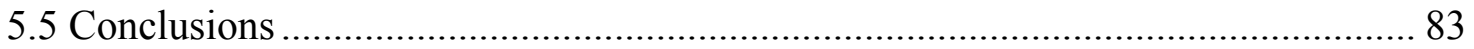

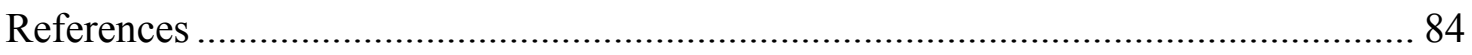

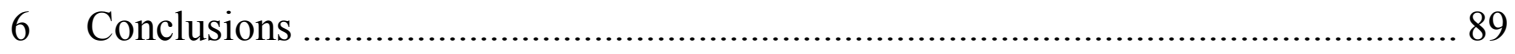

6.1 Preliminary Phase Conclusions ....................................................................... 90

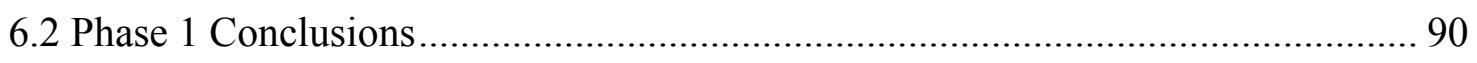

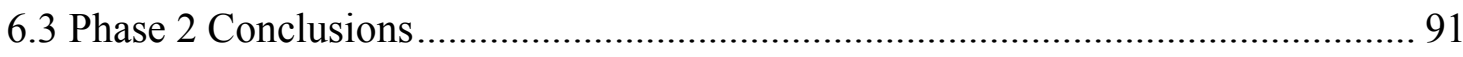

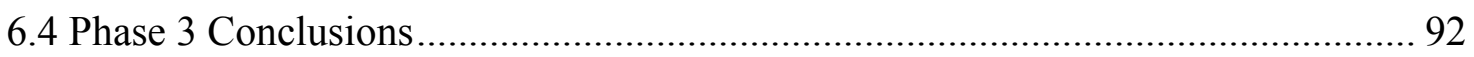

6.5 Overall Conclusions and Future Work............................................................... 93

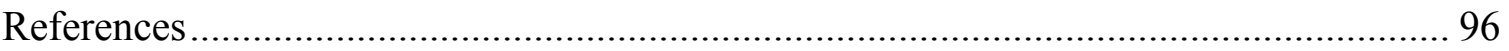

Appendix A - Biofilter Design ............................................................................... 102

Appendix B - Total Phosphorous (TP) Data (Lab Scale)............................................. 107

Appendix C - Potassium Data (Lab Scale) ................................................................. 109

Appendix D - t-test Data ...................................................................................... 110

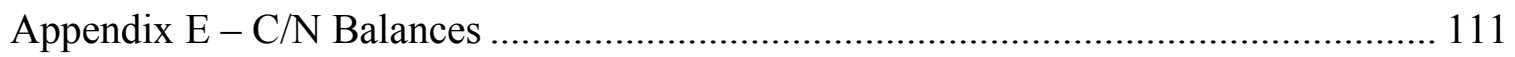




\section{List of Tables}

Table 2.1: Typical range of parameters of sand media for SSF (adapted from AWWA, 2012) 6

Table 2.2: Rapid sand filter configurations (adapted from Crittenden et al., 2012) .......... 9

Table 2.3: Typical values for rapid filter media parameters ....................................... 9

Table 2.4: Approximate BOM removals at $5{ }^{\circ} \mathrm{C}$ and $20^{\circ} \mathrm{C}$ (adapted from Liu et al., 2001)

Table 2.5: Backwash procedure details (adapted from Emelko et al., 2006) .................. 16

Table 2.6: Organics removal for chlorinated vs non-chlorinated backwash (Miltner et al.,

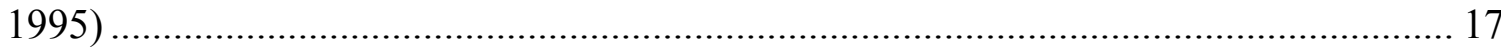

Table 2.7: Removal of formaldehyde and oxalate (adapted from Wert et al, 2008) ........ 20

Table 2.8: Summary of parameter removal $\%$ and filter specifications ......................... 20

Table 2.9: Characteristics of the two types of GAC used during this study .................... 22

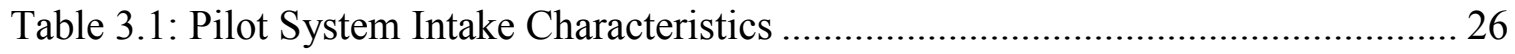

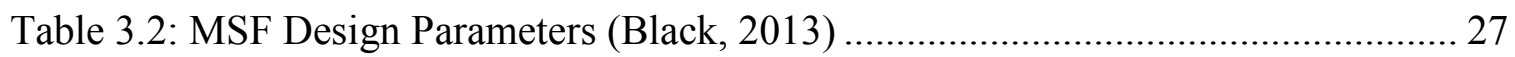

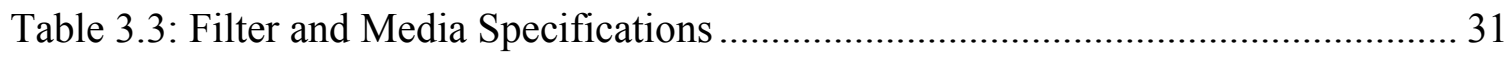

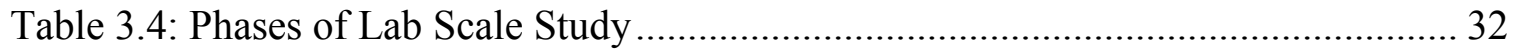

Table 3.5: Backwash Procedures for Phase 1, 2 and 3 ............................................. 35

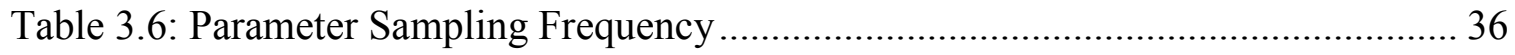

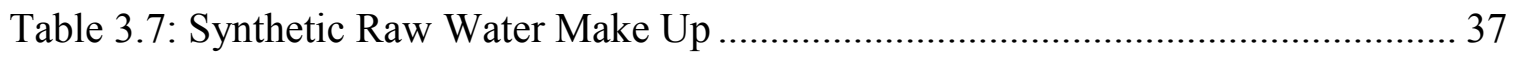

Table 4.1: Raw water quality of Ottawa River ...................................................... 44

Table 4.2: t-test analysis on \%DOC removal between Train 1 and $2(\mathrm{n}=17) \ldots \ldots \ldots \ldots \ldots . . . . .49$

Table 4.3: Average influent and effluent values of UVA and SUVA for Train 1 and 2 .. 50 
Table 5.1: Experimental Phase Description.

Table 5.2: Comparison of average \%DOC removals at the end of pilot, lab scale studies

Table 5.3: Average, maximum and minimum values for $\mathrm{UVA}_{254}$ and $\mathrm{SUVA}_{254}$ for Phase

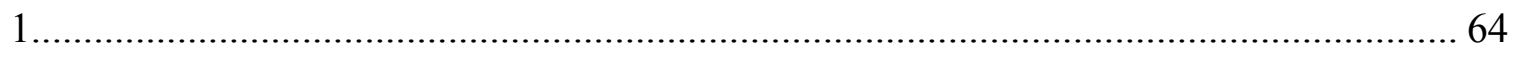

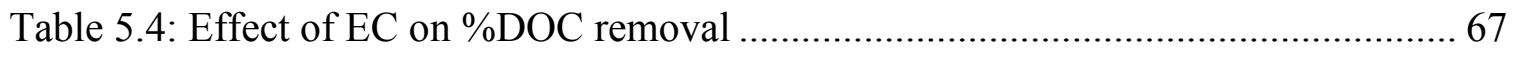

Table 5.5: Average influent, effluent UVA254 and SUVA254 values for Phase 2 ......... 68

Table 5.6: \%DOC removals over 3 phases .............................................................. 74

Table 5.7: Average influent, effluent UVA $_{254}$ and SUVA 254 values for Phase 3 ............ 76

Table 5.8: Average, maximum and minimum influent TN values for Phase 2 .............. 76

Table 5.9: ATP values for $2-\mathrm{NS} \mathrm{B}$ and $3-\mathrm{NL}$ at $5 \mathrm{~cm}$ and $18 \mathrm{~cm}$ depths .................. 81 


\section{List of Figures}

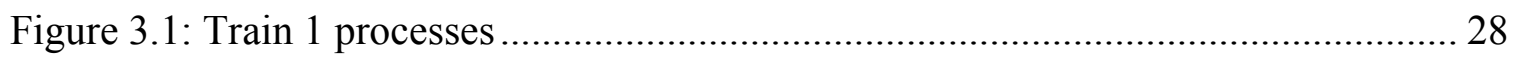

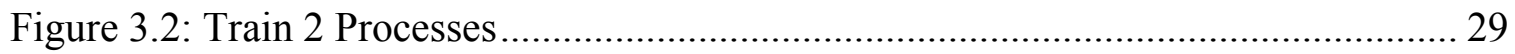

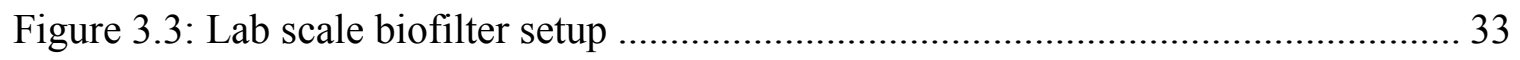

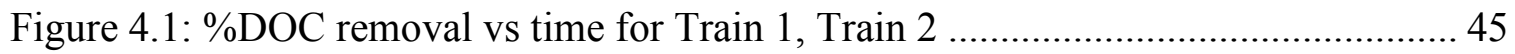

Figure 4.2: Top of the filter ATP concentrations for Train 1 and 2............................. 47

Figure 4.3: Impact of biomass concentration on \%DOC removal for SSF (Train 1) ...... 51

Figure 4.4: Relationship between ATP concentration and \%DOC removal for BAC 1

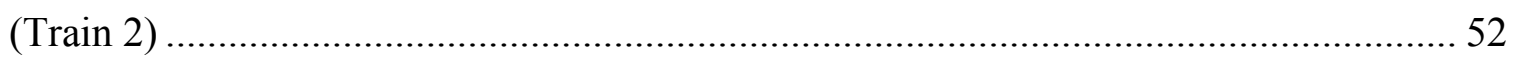

Figure 4.5: Relationship between ATP concentration and \%DOC removal for BAC 2

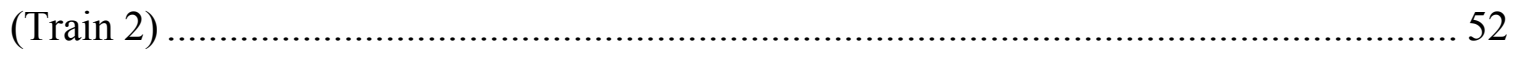

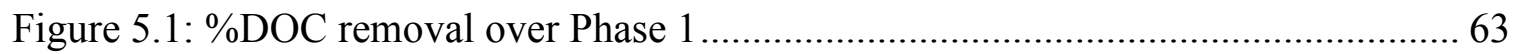

Figure 5.2: \%DOC removals over Phase $2(* \mathrm{EC}-$ Extended system clean - rinsed static

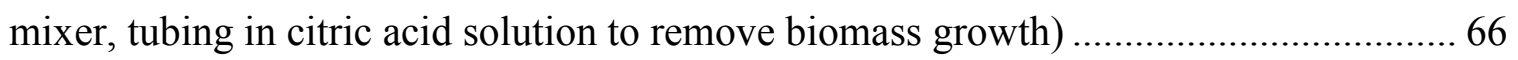

Figure 5.3: Impact of biomass concentration on \%DOC removal for 1 - NS A.............. 70

Figure 5.4: Impact of biomass concentration on \%DOC removal for 2 - NS B ............. 71

Figure 5.5: Impact of biomass concentration on \%DOC removal for 3 - NL ................ 71

Figure 5.6: Average \%DOC removals for Phase 3 ….............................................. 73

Figure 5.7: Average \%DOC removal for all columns over Phase 1, 2 and 3 ................. 74

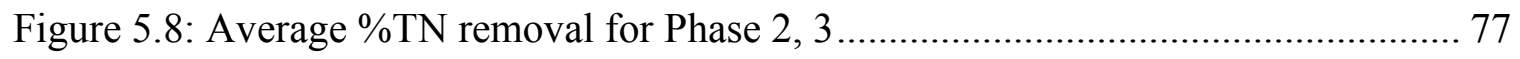

Figure 5.9: Average top and middle phospholipid counts for Phase 2 and 3 ................. 79

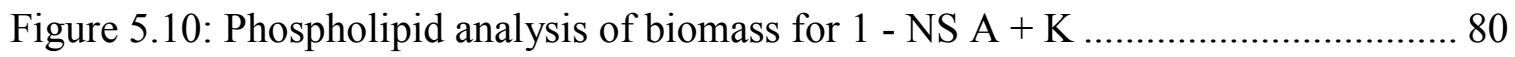

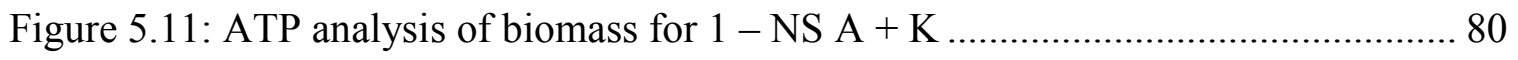


Figure 5.12: Potassium removal for 1 - NS A + K............................................... 82 


\section{List of Acronyms}

\begin{tabular}{|c|c|}
\hline $\mathrm{AOC}$ & Assimilable Organic Carbon \\
\hline ATP & Adenosine Tri Phosphate \\
\hline $\mathrm{BAC}$ & Biologically Activated Carbon \\
\hline $\mathrm{BDOC}$ & Biodegradable Organic Carbon \\
\hline $\mathrm{BOM}$ & Biological Organic Matter \\
\hline BWTP & Britannia Water Treatment Plant \\
\hline $\mathrm{C}: \mathrm{N}: \mathrm{P}$ & Carbon:Nitrogen:Phosphorous \\
\hline COD & Chemical Oxygen Demand \\
\hline DBP & Disinfection Byproduct \\
\hline $\mathrm{DOC}$ & Dissolved Organic Carbon \\
\hline EBCT & Empty Bed Contact Time \\
\hline $\mathrm{ES}$ & Effective Size \\
\hline GAC & Granular Activated Carbon \\
\hline MSF & Multi Stage Filtration \\
\hline SSF & Slow Sand Filtration \\
\hline SUVA & Specific Ultraviolet Absorbance \\
\hline THMFP & Trihalomethane Formation Potential \\
\hline $\mathrm{TN}$ & Total Nitrogen \\
\hline TOC & Total Organic Carbon \\
\hline TP & Total Phosphorous \\
\hline $\mathrm{UC}$ & Uniformity Coefficient \\
\hline UVA & Ultraviolet Absorbance \\
\hline
\end{tabular}




\section{Introduction}

\subsection{Problem Statement}

Surface waters such as rivers and lakes typically contain high concentrations of natural organic matter (NOM). Depending on availability, most water treatment utilities that service moderate to large sized communities use rivers and lakes as their water source. Untreated organic matter may make its way into the distribution system. This organic matter has been known to cause biological growth in the distribution system.

Organic matter also poses several other setbacks. For instance, residual NOM may result in the formation of taste and odor causing compounds thereby making the water less palatable. Further, NOM combines with disinfectants being used in a treatment process resulting in the formation of disinfection by products (DBPs) which are known to be carcinogenic in nature (McGeehin et al., 1993; Cantor et al., 1998; Singer 1999).

A low cost, small footprint option for effective removal of NOM is biofiltration. Biofiltration refers to the use of metabolic processes of a bacterial community attached to a filter medium to improve process performance. However, in order for biofiltration to perform optimally, it is critical that the bacterial community within the filter is receiving nutrients in an adequate ratio. The primary nutrient sources for biological growth are carbon $(\mathrm{C})$, nitrogen $(\mathrm{N})$ and phosphorous $(\mathrm{P})$.

It has been observed that for phosphorous concentrations less than $5 \mu \mathrm{g} / \mathrm{L}$, the common method for bacteria to transport phosphorous across their membranes (called phosphorous inorganic transport) is hindered (Rosenberg, 1987; Torriani-Gorini, 1994). Typically in drinking water biofiltration, $\mathrm{C}: \mathrm{N}: \mathrm{P}$ ratios less than 100:10:1 on a mol basis are considered 
a hindrance to optimal biomass performance (LeChevallier et al., 1991). Phosphorous concentrations less than $5 \mu \mathrm{g} / \mathrm{L}$ may result in C:N:P ratios less than 100:10:1. As such, biological filtration for carbon uptake has been found to benefit from phosphorous supplementation (Nishijima et al., 1997; Sang et al., 2003; Xin et al., 2003; Lauderdale et al., 2012).

The Britannia Water Treatment Plant (BWTP) in Ottawa, Ontario, Canada supplies water to the city of Ottawa and the surrounding areas. BWTPs raw water source is the Ottawa River which is highly phosphorous limited (average concentrations $<2 \mu \mathrm{g} / \mathrm{L}$ ). Carleton University (Ottawa, Ontario, Canada) in conjunction with Humber College (Toronto, Ontario, Canada) and MSFilter Inc. commissioned a pilot scale, multi-stage filtration system at the BWTP. It was hoped that an understanding could be garnered vis a vis the impact of nutrient limited conditions on filter biomass growth and biofilter performance. Following this study period, the aim was to analyze the effects of nutrient supplementation on biofilter performance in a controlled lab scale environment.

\subsection{Research Objectives}

In this study, the impact of nutrient limited conditions was studied on a pilot scale multistage filtration system. This constituted the preliminary phase of the study. These raw water conditions were then replicated in the lab on three newly designed biofilter columns; using the same C:N:P ratio as that of the Ottawa River. This formed Phase 1 of the research study. Phase 1 was the conditioning phase wherein the lab scale columns were operated at conditions similar to those at BWTP. Following this, nitrogen and phosphorous were added to two of the three columns to provide a more balanced C:N:P ratio while the last column remained nutrient limited to serve as a control. This constituted Phase 2. In Phase 3, 
potassium was added to one of the $\mathrm{N}$ and $\mathrm{P}$ supplemented biofilters to assess its impact on drinking water biological filters. Potassium has been shown to be an important factor in the uptake of phosphorous in wastewater treatment (Brdjanovic et al., 1996). However, its impact on drinking water filters has yet to be studied.

Thus, the research objectives were as follows:

- Develop an understanding of nutrient limited conditions and their impact on biofiltration performance

- Complete design, construction and setup of three lab scale dual media columns

- Assess the impact of nitrogen and phosphorous addition in different concentrations (thereby yielding different $\mathrm{C}: \mathrm{N}: \mathrm{P}$ ratios) on biofilter performance

- Assess the impact of potassium addition on drinking water biofiltration performance 


\section{Literature Review}

This chapter seeks to provide the reader with an understanding of the various types of biofilters available (for drinking water treatment), their pretreatment methods and design considerations. Further, certain sections provide details by various researchers with regards to organics removal, ammonia (nitrogen) removal and biofilters used as pretreatment for membranes. Impacts of the addition of phosphorous as reported in literature have also been discussed.

\subsection{Biofiltration in Drinking Water Treatment}

Biofiltration processes for removing natural organic matter have been in use since the 1970s (in Europe) and gained prominence in the 1980s is North America (Uhl, 2000). This prominence stemmed from the discovery that potable drinking water leaving a water treatment plant could cause significant microbial regrowth in water distribution pipelines (Chaudhary et al., 2003). Several water components such as $\mathrm{NH}_{4}^{+}-\mathrm{N}, \mathrm{NO}^{2-}, \mathrm{Fe}^{2+}$ and biodegradable organic matter $(\mathrm{BOM})$ are responsible for regrowth, thus making the potable water biologically unstable (Chaudhary et al., 2003). As well, it should be noted that natural organic matter (NOM) present in the source water is a precursor for the formation of disinfection by-products (DBPs) which are carcinogenic in nature and biologically activated carbon (BAC) filtration provides an effective means of removing NOM (Dussert, and Van Stone, 1994; Hozalski et al., 1999; Simpson, 2008). 


\subsection{Biofilter Types}

\subsubsection{Slow Sand Filters (SSF)}

SSFs are an economical, easy to operate and reliable technology to treat drinking water. A SSF consists of a bed of sand placed over an underdrain support (usually gravel). Removal within a slow sand filter takes place through 2 means (AWWA 2012):

- Biological processes

As the water passes through the sand bed, it encounters a thin, slimy layer at the top of the bed. This is known as the schmutzdecke. It is a biofilm layer which contains various microorganisms such as plankton, bacteria, rotifers, etc. This active biofilm layer captures organic matter passing through it and breaks it down.

- Physico-chemical processes

Once the water passes through the schmutzdecke, physical removal mechanisms such as straining and physico-chemical processes such as adsorption come into effect.

SSF may require pre-treatment depending on the quality of surface water being treated. These may include sedimentation, roughing filtration or a process of sedimentation, coagulation and roughing filtration (Huisman and Wood, 1974).

Advantages of a slow sand filter include (Manz, 2004):

- Ease of construction

- Ease of operation and maintenance

- Effectiveness in removing non-colloidal suspended particles

Disadvantages of a slow sand filter include (Manz, 2004): 
- Low flow rates through the filter

- Need for continuous flow to preserve bacterial removal characteristics

- Limitations for removing colloid sized particles

Table 2.1: Typical range of parameters of sand media for SSF (adapted from AWWA, 2012)

\begin{tabular}{|c|c|}
\hline Parameter & Accepted range \\
\hline Effective size $(\mathrm{mm})$ & $0.15-0.4$ \\
\hline Uniformity coefficient & $1.5-3.6$ \\
\hline Filtration rate $(\mathrm{m} / \mathrm{hr})$ & $0.04-0.4^{*}$ \\
\hline Bed depth $(\mathrm{m})$ & $0.46-1.52$ \\
\hline Available head loss $(\mathrm{m})$ & $0.76-4.3$ \\
\hline
\end{tabular}

*Filtration rates above $0.29 \mathrm{~m} / \mathrm{hr}$ require pretreatment

SSF operation takes place over 2 stages i.e. filtration and regeneration. Due to the low filtration rates, headloss buildup is slow and can take several months. Once the headloss limit is reached, the filter is taken out of service i.e. drained and cleaned. Cleaning of SSFs takes place through an operation known as scraping. Here, the schmutzdecke along with a small amount of sand $(1-2 \mathrm{~cm})$ is removed. This process continues until the sand reaches a bed depth of approximately $0.5 \mathrm{~m}$. At this stage, the sand must be replenished to achieve the original bed depth. (AWWA, 2012; Crittenden et al., 2012)

\subsubsection{Rapid Filtration}

Rapid filtration, like SSF, consists of 2 stages viz. a filtration stage (particles accumulate on the media bed) and a backwash stage (to remove accumulated solids). During filter operation, the filter becomes clogged which results in an increase in head loss. In such a 
scenario, the filter is taken offline and backwashed with an upflow of the treated effluent from the filter. Sometimes, the backwash may be supplemented with air scour (Amirtharajah, 1993) or chlorine (Emelko et al., 2006).

The trigger for backwash can be one of the following (AWWA, 2012):

- Head loss reaches a certain available or minimum established limit. Backwashing must be done to maintain the flow rate

- Filtrate quality deteriorates

- Filters can be backwashed after a certain time limit (usually 3 or 4 days)

The modified Ergun equation to calculate the empty bed head loss is as follows:

$$
h_{L}=\left[\frac{\mathrm{K}_{\mathrm{v}}(1-\varepsilon)^{2}}{\varepsilon^{3}} \frac{\mu \mathrm{vL}}{\rho_{\mathrm{w}} \mathrm{g}(\psi \mathrm{d})^{2}}\right]+\left[\mathrm{K}_{\mathrm{I}}\left(\frac{1-\varepsilon}{\varepsilon^{3}}\right) \frac{\mathrm{Lv}^{2}}{\mathrm{~g} \psi \mathrm{d}}\right]
$$

Where,

$$
\begin{aligned}
& \mathrm{h}_{\mathrm{L}}=\text { Empty bed head loss }(\mathrm{m}) \\
& \mu=\text { Viscosity of Water }(\mathrm{kg} / \mathrm{m} . \mathrm{s}) \\
& \rho_{\mathrm{w}}=\text { Density of Water }\left(\mathrm{kg} / \mathrm{m}^{3}\right) \\
& \mathrm{L}=\text { Depth of Bed }(\mathrm{m}) \\
& \varepsilon=\text { Porosity of Media } \\
& \mathrm{d}=\text { Effective Size of Media }(\mathrm{m}) \\
& \mathrm{g}=\text { Acceleration due to gravity }=9.81 \mathrm{~m} / \mathrm{s}^{2} \\
& \mathrm{v}=\text { Filtration Rate }(\mathrm{m} / \mathrm{hr}) \\
& \psi=\text { Sphericity }
\end{aligned}
$$

During the filtration stage, the effluent turbidity is monitored to gauge filter performance. Immediately after backwash, the effluent turbidity spikes. This is because the filter is 
undergoing a ripening process. Here, the media undergoes conditioning and is regaining its capacity to efficiently capture particles. Particles captured on the surface of the media act as additional collectors and can improve filter performance during its run time. Typically, ripening periods may vary from 15 minutes to 2 hours. (Crittenden et al., 2012)

Rapid filters are able to achieve filtration rates upto 100 times greater than SSF (Crittenden et al., 2012). This is due to:

- Filter beds contain processed granular media. This media is more uniform than that found in nature

- Coagulation and flocculation are employed as pretreatment methods

- Effective removal of accumulated solids from the bed due to various mechanical and hydraulic methods

Rapid filters can be classified on the basis of the media used. Media used in rapid filters includes sand, anthracite coal, granular activated carbon (GAC), garnet and ilmenite (AWWA, 2012; Crittenden et al., 2012). Various configurations are possible using these media. A summary of these configurations has been provided in Table 2.2. 
Table 2.2: Rapid sand filter configurations (adapted from Crittenden et al., 2012)

\begin{tabular}{|c|c|c|}
\hline Filter Configuration & Commonly Used Media & Media Depth (m) \\
\hline Monomedia & Sand & $0.6-1.8$ \\
\hline Dual Media & $\begin{array}{c}\text { Anthracite over sand or } \\
\text { GAC over sand }\end{array}$ & $\begin{array}{c}\text { Anthracite }-0.45-0.6 \mathrm{~m} \\
\text { or } 1.5-1.8 \mathrm{~m} \\
\text { Sand }-0.23-0.3 \mathrm{~m}\end{array}$ \\
\hline Tri-media & $\begin{array}{c}\text { Anthracite at the top, sand } \\
\text { in the middle and garnet or } \\
\text { ilmenite at the bottom }\end{array}$ & $\begin{array}{c}\text { Anthracite }-0.45-0.6 \\
\text { Sand }-0.23-0.3 \\
\text { Garnet } / \text { ilmenite }-0.1- \\
0.15\end{array}$ \\
& \multicolumn{2}{|}{} \\
\hline
\end{tabular}

Typical parameter values for rapid filter media have been provided in Table 2.3

Table 2.3: Typical values for rapid filter media parameters (adapted from Crittendenet al., 2012)

\begin{tabular}{|c|c|c|c|c|c|c|}
\hline Parameter & Unit & Garnet & Ilmenite & Sand & Anthracite & GAC \\
\hline $\begin{array}{c}\text { Effective } \\
\text { Size (ES) }\end{array}$ & $\mathrm{mm}$ & $0.2-0.4$ & $0.2-0.4$ & $0.4-0.8$ & $0.8-2.0$ & $0.8-2.0$ \\
\hline $\begin{array}{c}\text { Uniformity } \\
\text { Coefficient } \\
\text { (UC) }\end{array}$ & N/A & $1.3-1.7$ & $1.3-1.7$ & $1.3-1.7$ & $1.3-1.7$ & $1.3-2.4$ \\
\hline Porosity & $\%$ & $45-58$ & - & $40-43$ & $47-52$ & - \\
\hline Density & $\mathrm{g} / \mathrm{ml}$ & $3.6-4.2$ & $4.5-5.0$ & 2.65 & $1.4-1.8$ & $1.3-1.7$ \\
\hline
\end{tabular}

-Data not available

\subsection{Biofilter Pre-Treatment}

\subsubsection{Ozone}

Ozone has been used as a pre-treatment method for biofiltration. Ozonation allows for the breakup of NOM into more readily biodegradable dissolved organic carbon (BDOC) 
(Nishijima et al, 2003). Ozonation is employed prior to biofiltration for oxidation purposes

(Camel and Bermond, 1998; Nishijima et al, 2003; von Gunten, 2003).

The ozone action is divided into 3 phases (Camel and Bermond, 1998):

- Pre-oxidation

Elimination of taste and odour causing compounds (such as MIB and geosmin), removal of suspended solids, turbidity, partial degradation of NOM and microorganism inactivation

- Intermediate oxidation

Degradation of toxic micropollutants, increasing biodegradability of BDOC (converted from NOM in pre-oxidation) and removal of trihalomethane precursors.

- Final disinfection

Elimination of remaining microorganisms and minimization of disinfectant byproduct formation

Oxidation of NOM can be either direct or indirect. When oxidation is direct, ozone is the primary oxidant. This is a result of reaction to double bonds or activated aromatic systems. Reactions with amines or sulfides are also a possibility. In the case of an indirect reaction, NOM reacts with the $-\mathrm{OH}$ radical formed from the decay of ozone in water. Ozone is a highly selective oxidant whereas the $-\mathrm{OH}$ radical is non-selective (von Gunten, 2003).

It is important to note that one must determine the optimum ozone dosage. Beyond a certain value, increasing ozone dosage does not guarantee DOC removal. This is because the BDOC resulting from DOC breakdown will eventually begin consuming ozone (Nishijima 
et al, 2003). As a result, all the BDOC will be consumed before entering the biofilter. This will result in lower DOC removals through the process.

Nishijima et al. (1998) evaluated the performance of $\mathrm{O}_{3} / \mathrm{BAC}$ (910 days) versus BAC without ozonation (420 days). DOC removal and trihalomethane formation potential (THMFP) removal were investigated. It was observed that, for an ozone dose of $2.5 \mathrm{mg}$ $\mathrm{O}_{3} / \mathrm{mg} \mathrm{C}$, DOC removal and THMFP removal were $36 \%$ and $57 \%$ respectively for the $\mathrm{O}_{3} / \mathrm{BAC}$ process. This was despite the saturation of the GAC after 300 days (characterized by non-removal of non-BDOC). Ozonation was able to increase the BDOC fraction of the influent water from $7 \%$ to $32 \%$.

Nishijima et al. (2003) sought to compare the impact of multi-stage ozonation versus single stage ozonation on DOC removal. Single stage ozonation was carried out for 5, 10, 15, 20, 30 and 60 minutes with an ozone dosage of 3.2 or $5.2 \mathrm{mg} / \mathrm{min}$. It was observed that DOC concentration reduced from $10.4 \mathrm{mg} / \mathrm{L}$ (pre-ozonation) to $7 \mathrm{mg} / \mathrm{L}$ (post biodegradation) for a 5 minute dosing period with single stage ozonation. Between 5 minutes and 60 minutes of dosing, no differences were apparent in DOC removal. In contrast, multi-stage ozonation (4 stages, each 5 minutes or 15 minutes) with a dosage of $2.3 \mathrm{mg} / \mathrm{min}$ were found to reduce DOC from $10.4 \mathrm{mg} / \mathrm{L}$ to $5.1 \mathrm{mg} / \mathrm{L}$ (for 5 minute dosages) and $3.6 \mathrm{mg} / \mathrm{L}$ (for 15 minute dosages).

\subsection{Biofilter Design}

\subsubsection{Media}

GAC, sand and anthracite have been used as biofilter media. GAC can be a more robust option for organics removal from surface waters (LeChevallier et al., 1991). 
A bench scale study conducted by Liu et al (2001) investigated the effects of media type and chlorinated backwash on BOM removal. It was found that GAC/sand filters showed effective BOM removal at $5{ }^{\circ} \mathrm{C}$ and $20^{\circ} \mathrm{C}$ compared to anthracite/sand filters. A summary of removals obtained in this study has been provided below along with a comparison to anthracite media.

Table 2.4: Approximate BOM removals at $5{ }^{\circ} \mathrm{C}$ and $20^{\circ} \mathrm{C}$ (adapted from Liu et al., 2001)

\begin{tabular}{|c|c|c|c|c|}
\hline & \multicolumn{2}{|c|}{ GAC/Sand Media } & \multicolumn{2}{|c|}{ Anthracite/Sand Media } \\
\hline $\begin{array}{c}\text { BOM } \\
\text { Component }\end{array}$ & $\begin{array}{c}\text { \% Removal } \\
\text { at } 5{ }^{\circ} \mathrm{C}\end{array}$ & $\begin{array}{c}\text { \% Removal at } \\
20{ }^{\circ} \mathrm{C}\end{array}$ & $\begin{array}{c}\text { \% Removal } \\
\text { at } 5{ }^{\circ} \mathrm{C}\end{array}$ & $\begin{array}{c}\text { \% Removal at } \\
20{ }^{\circ} \mathrm{C}\end{array}$ \\
\hline Acetate & 85 & 90 & $45-85$ & $85-90$ \\
\hline Formate & 85 & 90 & $30-80$ & 90 \\
\hline Formaldehyde & 85 & 95 & 95 & $10-85$ \\
\hline Glyoxal & $65-80$ & 79 & $75-80$ & $10-55$ \\
\hline
\end{tabular}

Thiel et al. (2006) conducted a pilot scale study to compare the performance of activated carbon and anthracite. At an EBCT of 8 minutes, DOC removals by GAC varied from approximately $11 \%$ to $14 \%$ whereas by anthracite removals ranged from approximately $1 \%-3 \%$. An increase in EBCT to 16 minutes resulted in DOC removals in the range of $15 \%-20 \%$ for GAC and approximately $2 \%$ to $7 \%$ for anthracite.

In a full scale study, Emelko et al. (2006) found that at warmer temperatures $\left(21-24{ }^{\circ} \mathrm{C}\right)$, GAC and anthracite showed similar TOC removals i.e. the differences in removal were statistically insignificant. At colder temperatures $\left(1-3{ }^{\circ} \mathrm{C}\right)$, median TOC removals were $23 \%$ by GAC filters and $14 \%$ by anthracite filters. 


\subsubsection{Empty Bed Contact Time (EBCT)}

EBCT refers to the period of time the water to be treated is in contact with the filter media. It is a parameter that is commonly used to determine the expected performance of biofilters for organics removal.

Yang et al. (2010) compared different treatment processes post conventional treatment (coagulation, flocculation, sedimentation and rapid sand filtration) at a pilot scale. Water from the rapid sand filter was passed through $\mathrm{GAC}$ and ozone/BAC processes with different EBCTs. The GAC column had an EBCT of 27.1 min while the BAC column had an EBCT of 39.1 min. Non-purgeable DOC (NPDOC) removals by rapid sand filtration process was $33.9 \%$. The GAC process increased NPDOC removal efficiency by $10 \%$ compared to the rapid sand filter whereas $\mathrm{O}_{3} / \mathrm{BAC}$ process increased removal efficiency by $30 \%$ compared to the rapid sand filter.

Basu and Huck (2004a) studied humic acid removal by biofiltration on a lab scale. Anthracite/sand columns were used with an EBCT of 22 minutes. Removal of humic acid varied from 0 to $32 \pm 19 \%$ (the \pm indicates standard deviation).

Wert et al (2008) studied the impact of EBCT on AOC removal. 2 anthracite/sand filters with EBCT of 3.2 min and 8.3 min were employed. In both cases, AOC removal stabilized to around $60 \%$ after 175 days of operation.

It is unclear what the ideal EBCT range is based on data present in literature. Indeed, the results in literature have been conflicting. This could point to a need to investigate other operational parameters in conjunction with EBCT and their effects on organic carbon removal in drinking water biofilters. 


\subsubsection{Filter Acclimation and Filter Depth}

Acclimation refers to the period of time required for a biofilter to begin operating under steady state conditions i.e. DOC or BOM removal is at its maximum capacity. Filter acclimation periods vary and depend on several factors such as temperature, source water characteristics and type of media. For instance, in the case of GAC media, removal of contaminants initially takes place via adsorption. Once the adsorptive capacity of the GAC has been exhausted, a biofilm begins to colonize the media and removal gradually shifts to biodegradation from adsorption (Simpson, 2008).

Interestingly, Velten et al. (2011) measured biomass development throughout the depth of an $\mathrm{O}_{3} / \mathrm{BAC}$ filter from start-up with virgin GAC media. Initially, less than $20 \%$ of the influent DOC was found in the effluent. However, this was attributed to the adsorptive capacity of the virgin GAC media. Biomass accumulation throughout the depth of the bed was observed, which ceased after a period of 90 days indicating steady state. Biomass was quantified using adenosine tri-phosphate (ATP) analysis. ATP is the primary energy carrier in living cells (Caprita et al., 2006). These steady state values ranged from $1.17( \pm 0.2) \times$ $10^{-6} \mathrm{gATP} / \mathrm{g}$ GAC at a depth of $10 \mathrm{~cm}$ versus $0.8( \pm 0.2) \times 10^{-6} \mathrm{gATP} / \mathrm{g}$ GAC at a depth of $115 \mathrm{~cm}$. This would indicate biofilm activity throughout the depth of the filter bed, contradictory to Urfer and Huck (2001) who suggested biological activity occurs only within the first few centimeters of a biofilter.

Boon et al. (2011) found average biomass concentration of $1.2 \times 10^{6} \mathrm{gATP} / \mathrm{g}$ GAC at a depth of $10 \mathrm{~cm}$ versus $0.8 \times 10^{6} \mathrm{gATP} / \mathrm{g}$ GAC at a depth of $115 \mathrm{~cm}$ after a 90 day start-up period. DOC removals normalized for the active biomass (gATP) at this time were found 
to be below $1.2 \mathrm{mgL}^{-1} \mathrm{gATP}^{-1}$ at $10 \mathrm{~cm}$ and in excess of $6.6 \mathrm{mgL}^{-1} \mathrm{gATP}^{-1}$ at a depth of 115 $\mathrm{cm}$.

\subsubsection{Filter Backwash}

Amirtharajah (1993) has suggested that filter backwash using water only may prove to be ineffective. He has suggested the supplementary use of air scour with a subfluidization water wash to improve the cleaning efficiency of a backwash. The air scour would increase the hydrodynamic shear experienced by the GAC particles during fluidization which would increase abrasions and collisions between them. A scenario known as collapse pulsing is achieved. Here, small voids are created which breakdown as the air passes upwards. This formation and breakdown of voids increases abrasions and collisions between the particles. It has also been suggested that the backwash water flow rate should be $20-50 \%$ of the minimum fluidization velocity of the media in order to achieve effective collapse pulsing.

Emelko et al. (2006) examined the effects of air scour and subfluidized backwash on TOC and oxalate removal. The various backwash procedures have been summarized in Table 2.5 . 
Table 2.5: Backwash procedure details (adapted from Emelko et al., 2006)

\begin{tabular}{|c|c|}
\hline Backwash Protocol & Details \\
\hline \multirow{4}{*}{$\begin{array}{l}\text { Standard } \\
\text { (Air Scour) }\end{array}$} & Air scour: $2 \mathrm{~min} ; 3 \mathrm{scfm} / \mathrm{sq} \mathrm{ft}$ \\
\hline & Settling time: $1 \mathrm{~min}$ \\
\hline & $\begin{array}{l}\text { Chlorinated low rate wash: } 9 \mathrm{~min} ; \\
10.7 \mathrm{~m} / \mathrm{hr}\end{array}$ \\
\hline & $\begin{array}{l}\text { Chlorinated high rate wash: 11-12 } \\
\text { min; } 42.7 \mathrm{~m} / \mathrm{hr}\end{array}$ \\
\hline \multirow{2}{*}{ No Air Scour } & $\begin{array}{l}\text { Chlorinated low rate wash: } 9 \text { min; } \\
\qquad 10.7 \mathrm{~m} / \mathrm{hr}\end{array}$ \\
\hline & $\begin{array}{l}\text { Chlorinated high rate wash: 11-12 } \\
\text { min; } 42.7 \mathrm{~m} / \mathrm{hr}\end{array}$ \\
\hline \multirow[b]{2}{*}{ Collapse Pulsing } & $\begin{array}{l}\text { Chlorinated low rate wash: } 9 \mathrm{~min} ; \\
10.7 \mathrm{~m} / \mathrm{hr}\end{array}$ \\
\hline & $\begin{array}{l}\text { Subfluidization wash with air } \\
\text { scour; } 7 \mathrm{~min} ; \\
\text { water wash }-7.3 \mathrm{~m} / \mathrm{hr} \\
\text { air scour } 3 \mathrm{scfm} / \mathrm{sq} \mathrm{ft}\end{array}$ \\
\hline
\end{tabular}

At both warmer temperatures $\left(21-24^{\circ} \mathrm{C}\right)$ and colder temperatures $\left(1-3{ }^{\circ} \mathrm{C}\right), \mathrm{GAC} /$ sand filters and anthracite sand filters showed no significant change in TOC removal with and without air scour. Both TOC and oxalate removal remained unaffected by collapse pulsing.

Liu et al. (2001) showed no significant impact on BOM removal for backwash water; chlorinated with $0.5 \mathrm{mg} \mathrm{Cl} / \mathrm{L}$ at $20{ }^{\circ} \mathrm{C}$ compared to when no chlorine was used in the backwash water. However, a decrease in glyoxal removal was observed for the anthracite/sand filter. At $5{ }^{\circ} \mathrm{C}$, a detrimental effect was observed on BOM removal for the same $\mathrm{Cl}_{2}$ concentration in the backwash water which was related to specific $\mathrm{BOM}$ components. For example, glyoxal removal was 55\% without chlorinated backwash water as opposed to $11 \%$ with chlorinated backwash water.

Miltner et al (1995) studied the effects of chlorinated backwash on the performance of dual media anthracite/sand filters. Chlorine dosages of 2.5 to $3 \mathrm{mg} / \mathrm{L}$ were applied. Biomass 
concentrations for the chlorinated backwash filter and another filter with non-chlorinated backwash were measured. Organics removal (TOC, methyl glyoxal, AOC-NOX, acetaldehyde, etc.) was also monitored. It was observed that chlorinated backwash reduced biomass concentration by $22 \%$ on average. Table 2.6 provides the mean $\%$ removal for certain measured organics from the study.

Table 2.6: Organics removal for chlorinated vs non-chlorinated backwash (Miltner et al., 1995)

\begin{tabular}{|c|c|c|}
\cline { 2 - 3 } \multicolumn{1}{c|}{} & \multicolumn{2}{c|}{ Mean \% Removal } \\
\hline Parameter & $\begin{array}{c}\text { Chlorinated } \\
\text { Backwash }\end{array}$ & Non-chlorinated backwash \\
\hline Methyl glyoxal & 62 & 97 \\
\hline Glyoxal & 21 & 97 \\
\hline AOC-NOX & 33 & 53 \\
\hline
\end{tabular}

As can be seen from Table 2.6, chlorinated backwash had an impact on the removal efficiencies of certain organic components.

It can be inferred from the above studies that backwashing is an important parameter in the design of filtration systems. Further, chlorinated backwash water can prove detrimental to biomass growth and hence can be detrimental to the development of an active biofilter. Backwash procedures should thus be tailored to suit the needs of the utility in order to optimize organics removal.

\subsection{Organics Removal}

In drinking water treatment, natural organic matter (NOM) is responsible for imparting colour to the water. If left untreated throughout the treatment process, NOM is a potential disinfection by-product precursor in the presence of certain disinfectants; such as chlorine. 
(Chae, 2002; Bekbolet et al., 2005; Sohn et al., 2007) Biofiltration with or without ozonation is effective in reducing the NOM content in the water source through mineralization of NOM by the microbes in the biofilm contained within the biofilter This can then be mineralized by the microbes in the biofilm on the biofilters. (Chaiket et al., 2002; Yavich et al., 2003; Yavich et al., 2004).

Temperature has been found to be an important parameter influencing BDOC removal (Laurent et al, 1999; Moll et al, 1999). Modeling results by Laurent et al. (1999) indicate that BDOC removal is highly dependent on empty bed contact time (EBCT) of the filters. It was found that for lower temperatures $\left(5{ }^{\circ} \mathrm{C}\right)$, an $\mathrm{EBCT}$ of 12 minutes would provide approximately $22 \% \mathrm{BDOC}$ removal. A similar EBCT for water at $25{ }^{\circ} \mathrm{C}$ could achieve approximately 50\% removal of BDOC. Moll et al. (1999) used sand filters operating at an EBCT of $7 \mathrm{~min}$ with a hydraulic loading rate of $3.6 \mathrm{~m} / \mathrm{hr}$. Influent water temperature varied from $5{ }^{\circ} \mathrm{C}$ to $35^{\circ} \mathrm{C}$. At $5{ }^{\circ} \mathrm{C}, \mathrm{DOC}, \mathrm{BDOC}$ and AOC removals were found to be $15 \%, 38 \%$ and $43 \%$ respectively. The corresponding removals at $35{ }^{\circ} \mathrm{C}$ were $24 \%, 60 \%$ and $57 \%$. Thus, the results showed a decrease in removal of DOC, BDOC and AOC at lower temperatures.

Mofidi (2005) conducted studies on biodegradable organic matter (BOM) removal at the Mills Water Treatment Plant in Southern California. Their goal was to achieve 70\% BOM removal. The plant was retrofitted with ozonation at the head of the treatment process to make the BOM more readily biodegradable. Two biofiltration modules (Module 3 and 4) were present at the plant. Each contained 16 anthracite/sand filters. BOM levels were monitored by analyzing samples for short chain carboxylic acids (CBXA). Module 4 was initially set up for use with spent media. As Module 4 came online in August 2004, a 70\% 
reduction in BOM was almost immediately achieved. The media for module 4 was then replaced by virgin media in January 2005. Due to the effects of cold climate (water temperature $\sim 8^{\circ} \mathrm{C}$ ), a BOM removal of less than $11 \%$ was observed for nearly 2 months. Following this, $45 \%$ removal was observed after 2.5 months of operation. It should be noted, however, that water temperature increased to $13.5^{\circ} \mathrm{C}$ during this period. Recovery to $70 \%$ BOM removal was attained only after 5 months of operation. Module 3 was brought online with virgin media in March 2005 (water temperature $\sim 14{ }^{\circ} \mathrm{C}$ ). No BOM removal was observed initially. $64 \%$ removal of BOM was observed after 3 months of operation. However, it remains likely that the increase in temperature is responsible for an increased BOM removal.

Wert et al (2008) examined the effects of various backwash procedures (dechlorinated backwash water versus chlorinated water with air scour) and varying filtration rates (4.8 $\mathrm{m} / \mathrm{hr}-14.6 \mathrm{~m} / \mathrm{hr}$ ) on BOM removal. BOM (measured as AOC) was unaffected by backwash procedures and filtration rates. A 60\% reduction in AOC was observed after 165 days of filter operation. Formaldehyde and oxalate acid were evaluated as the aldehyde and carboxylic acid portion of $\mathrm{BOM}$ respectively. An increased filtration rate led to a $20 \%$ reduction in oxalate removal. Table 2.7 gives a brief summary of formaldehyde and oxalate removals and the impact of backwashing strategies and filtration rates on their removal. 
Table 2.7: Removal of formaldehyde and oxalate (adapted from Wert et al, 2008)

\begin{tabular}{|c|c|c|c|c|}
\hline $\begin{array}{c}\text { BOM } \\
\text { Component }\end{array}$ & $\begin{array}{c}\text { Filter Influent } \\
\text { Concentration } \\
(\boldsymbol{\mu g} / \mathbf{L})\end{array}$ & $\begin{array}{c}\text { \% } \\
\text { Removal } \\
\text { after 165 } \\
\text { days }\end{array}$ & $\begin{array}{c}\text { Day from start- } \\
\text { up } \\
\text { biodegradation } \\
\text { observed }\end{array}$ & $\begin{array}{c}\text { Impact of } \\
\text { backwash/filtration } \\
\text { rate }\end{array}$ \\
\hline Formaldehyde & $11-20$ & 70 & 55 & Negligible \\
\hline Oxalate & $105 \pm 18$ & - & $65-104$ & $\begin{array}{c}\text { Lower filtration rate, } \\
\text { dechlorinated } \\
\text { backwash water } \\
\text { showed higher } \\
\text { removal }\end{array}$ \\
\hline
\end{tabular}

Table 2.8 provides a brief summary of parameter removals and filter specifications from various studies.

Table 2.8: Summary of parameter removal \% and filter specifications

\begin{tabular}{|c|c|c|c|c|}
\hline \multirow[b]{2}{*}{ Reference } & \multirow[b]{2}{*}{ Filter Specification } & \multicolumn{3}{|c|}{$\begin{array}{c}\text { Average Parameter } \% \\
\text { Removal }\end{array}$} \\
\hline & & BDOC & AOC & TOC \\
\hline $\begin{array}{l}\text { Lu et al. } \\
(2012)\end{array}$ & $\begin{array}{c}\mathrm{O}_{3} / \mathrm{BAC}, \text { Filtration rate }=1.5 \mathrm{~m}^{3} / \mathrm{hr} \\
\mathrm{EBCT}=15 \mathrm{~min}\end{array}$ & 72 & NM & NM \\
\hline $\begin{array}{l}\text { Liao et al. } \\
\text { (2013) }\end{array}$ & $\begin{array}{c}\mathrm{O}_{3} / \mathrm{BAC}, \text { Filtration rate }=8 \mathrm{~m}^{3} / \mathrm{hr}, \\
\mathrm{EBCT}=\mathrm{NP}\end{array}$ & NM & $51.2-60.6$ & NM \\
\hline \multirow{2}{*}{$\begin{array}{l}\text { Kong et al. } \\
\text { (2006) }\end{array}$} & $\begin{array}{c}\mathrm{O}_{3} / \mathrm{BAC}, \text { Ozone Dose }=2-8 \mathrm{mg} / \mathrm{L}, \\
\mathrm{EBCT}=11.5 \mathrm{~min}\end{array}$ & NM & 89 & 33.3 \\
\hline & $\mathrm{GAC}, \mathrm{EBCT}=11.5 \mathrm{~min}$ & NM & 69 & 21.1 \\
\hline \multirow{3}{*}{$\begin{array}{l}\text { Moll et al. } \\
\text { (1999) }\end{array}$} & $\begin{array}{c}\text { Sand, loading rate }=3.6 \mathrm{~m} / \mathrm{hr}, \mathrm{EBCT}= \\
7 \mathrm{~min}, \mathrm{~T}=5^{\circ} \mathrm{C}\end{array}$ & 38 & 43 & NM \\
\hline & $\begin{array}{c}\text { Sand, loading rate }=3.6 \mathrm{~m} / \mathrm{hr}, \mathrm{EBCT}= \\
7 \mathrm{~min}, \mathrm{~T}=20^{\circ} \mathrm{C}\end{array}$ & 60 & 55 & NM \\
\hline & $\begin{array}{l}\text { Sand, loading rate }=3.6 \mathrm{~m} / \mathrm{hr}, \mathrm{EBCT}= \\
7 \mathrm{~min}, \mathrm{~T}=35^{\circ} \mathrm{C}\end{array}$ & 60 & 57 & NM \\
\hline
\end{tabular}

NM - Not measured

NP - Not provided 
It is clear from the above information that several factors play a key role in organics removal. For instance, ozonation proves effective in improving AOC removal versus instances where ozonaion is not present. Filtration rates and temperature also play an important role. Unfortunately, information regarding the impacts of cold water temperature in drinking water biofilters is sparse and forms a potential avenue of research for the future.

\subsection{Nitrogen (Ammonia) Removal}

Nitrogen is found in surface water and ground water in the form of ammonia $\left(\mathrm{NH}_{4}{ }^{+}\right)$, nitrites $\left(\mathrm{NO}_{2}^{-}\right)$and nitrates $\left(\mathrm{NO}_{3}^{2-}\right)$. All these forms are undesirable in drinking water. Traditionally, breakpoint chlorination has been used to remove ammonia. However, this can be cost inhibitive (Wert et al., 2008) and can also result in a decrease in short-term chlorine demand (Andersson et al., 2001). Developing nitrification in biological filtration is a cost-effective method to achieve simultaneous BOM and ammonia removal. In nitrification, Nitrosomonas bacteria convert ammonia to nitrite. The Nitrobacter bacterial species then converts nitrite to nitrate. (Wert et al, 2008)

Olańczuk-Neyman and Bray (2000) studied the effects of chemical (15 mM sodium azide addition) and physical (high temperature treatment) inhibition on the growth of nitrifying bacteria. Sodium azide was inhibitory to the ammonia oxidising bacteria even after its removal from the filters.

Wert et al. (2008) found that biofiltration was able to convert ammonia to $50 \% \mathrm{NO}_{2}-\mathrm{N}$ and $50 \% \mathrm{NO}_{3}-\mathrm{N}$ in a column with $183 \mathrm{~cm}$ anthracite and $20 \mathrm{~cm}$ sand after 290 days of operation (at the end of the study). Here, a high loading rate $(14.6 \mathrm{~m} / \mathrm{hr}$ ) and low EBCT ( 8.3 minutes) were used. Conversion of ammonia to nitrite began after 130 days. Full nitrification was 
observed after 170 days. In contrast, filters with $53 \mathrm{~cm}$ anthracite and $25 \mathrm{~cm}$ sand operating at a loading rate of $4.8 \mathrm{~m} / \mathrm{hr}(\mathrm{EBCT}=9.7$ minutes $)$ achieved complete ammonia removal by day 99 .

Andersson et al. (2001) present an interesting comparison between ammonia removals at a pilot scale and full scale level. The study made use of 2 different kinds of GAC media: closed superstructured (CS) and open superstructured (OS). Table 2.9 below provides some information on the types of GAC used.

Table 2.9: Characteristics of the two types of GAC used during this study (adapted from Andersson et al., 2001)

\begin{tabular}{|c|c|c|}
\hline Characteristics & CS GAC & OS GAC \\
\hline Origin & Bituminous coal & Wood \\
\hline Type of Activation & Physical & Chemical \\
\hline Effective Size (mm) & $0.55-0.75$ & 0.97 \\
\hline $\begin{array}{c}\text { Uniformity Coefficient } \\
(\mathrm{mm})\end{array}$ & $1.6-2.1$ & $<1.7$ \\
\hline $\begin{array}{c}\text { Dry Density }(\mathrm{g} / \mathrm{cm} 3) \\
\text { Specific Surface Area } \\
(\mathrm{m} 2 / \mathrm{g})\end{array}$ & 0.42 & 0.35 \\
\hline Size of Pores $(\mathrm{mm})$ & $900-1100$ & 1050 \\
\hline \multicolumn{2}{|c|}{} \\
\hline
\end{tabular}

At a pilot scale, while they observed a decrease in nitrification at lower temperatures, a decrease in the quantity of nitrifying biomass attached to the media was not observed. OS media showed greater reduction in ammonia than CS media ( $77 \%$ versus $55 \%)$ during the initial filter acclimation period. At a full scale, for temperatures greater than $10 \mathrm{C}$, OS media showed 98\% removal while CS media showed 90\% removal. The increased removals compared to the pilot scale filters were thought to be a result of greater EBCT for the full scale columns (20-30 minutes versus 3.6 minutes). 
Stembal et al. (2005) evaluated the concentration profiles of $\mathrm{NH}_{3}-\mathrm{N}, \mathrm{NO}_{2}-\mathrm{N}$ and $\mathrm{NO}_{3}-\mathrm{N}$ through the depths of 4 rapid sand filters at varying filtration rates for groundwater sources. For filters pre-acclimated with nitrifying bacteria, all the incoming ammonia was converted to $\mathrm{NO}_{3}-\mathrm{N}$ at a depth between $0.4 \mathrm{~m}$ and $0.8 \mathrm{~m}$. For filters not acclimated, the ammonia removals were observed within 10 days of operation. Complete removal of ammonia was observed within 25 days. This was accompanied by a spike in the nitrite values which eventually decreased within another 10 days as the nitrite was converted to nitrate.

Aslan and Cakici (2007) studied denitrification in slow sand filters. Sand with an ES of 0.5 $\mathrm{mm}$ and UC of 1.23 was used. Filtration rates varied from $0.015 \mathrm{~m} / \mathrm{hr}-0.06 \mathrm{~m} / \mathrm{hr}$ for an influent $\mathrm{NO}_{3}-\mathrm{N}$ concentration of $22.6 \mathrm{mg} \mathrm{NO}-\mathrm{N} / \mathrm{L}$. Due to the varying filtration rates, the nitrogen loading rates varied. Acetic acid was used as the carbon source. An optimum $\mathrm{C} / \mathrm{N}$ ratio was determined for $\mathrm{NO}_{3}-\mathrm{N}$ removal which was found to be 1.8 . At this ratio, $90 \%$ $\mathrm{NO}_{3}-\mathrm{N}$ removal was achieved. It was also observed that as the filtration rates increased, the NO3-N removal decreased. Additionally, it was found that a majority of the $\mathrm{NO}_{3}-\mathrm{N}$ removal occurs within the top $20 \mathrm{~cm}$ of the filter bed.

\subsection{Nutrient Supplementation}

A study conducted in Finland (Miettinen et al., 1997) found that phosphorous is an important compound to regulate microbial growth. Heterotrophic plate counts were determined for treated water from 3 surface water sources, 2 artificially recharged ground water sources and 1 ground water source post phosphorous addition. Phosphorous dosages varied from $1 \mu \mathrm{g} \mathrm{P} / \mathrm{L}$ to $50 \mu \mathrm{g} \mathrm{P} / \mathrm{L}$. Strong correlations were determined between phosphorous and AOC availability to microbial growth. It was determined that AOC alone 
was not the driving catalyst but rather its availability in the presence of phosphorous that drove the process of growth.

Nishijima et al (1997) carried out phosphorous supplementation experiments in a $220 \mathrm{~mL}$ continuously mixed reactor containing $110 \mathrm{~mL}$ of GAC. For an initial DOC concentration of $9.5 \mathrm{mg} / \mathrm{L}$, the average effluent DOC value from the filter was $3.9 \mathrm{mg} / \mathrm{L}$ for GAC with adsorbed phosphorous (3.2 $\mathrm{mg} \mathrm{P} / \mathrm{g}$ GAC) and $8.7 \mathrm{mg} / \mathrm{L}$ for GAC without adsorbed phosphorous. After 47 days, the influent to the GAC without adsorbed phosphorous was spiked with $0.1 \mathrm{mg} \mathrm{P} / \mathrm{L}$. This resulted in a dramatic decrease in DOC from $8.7 \mathrm{mg} / \mathrm{L}$ to 2.2 $\mathrm{mg} / \mathrm{L}$.

Xin et al (2003) studied the effects of phosphorous supplementation on 2 pilot scale GAC/sand filters. Each filter had a hydraulic loading between 7.5 and $8.5 \mathrm{~m} / \mathrm{hr}$. This corresponded to an EBCT in the range of $6.4-7.2$ min. A 54\% increase was observed in the heterotrophic plate counts after phosphorous addition. An increase in the permanganate index removal $\left(\mathrm{COD}_{\mathrm{Mn}}\right)$ was also observed $(20.56 \%$ removal with $\mathrm{P}$ addition versus 14.54\% without $\mathrm{P}$ addition).

An optimal C:N:P ratio of 100:10:1 on a mol basis is desirable for organic carbon removal in drinking water biofilters (LeChevallier et al., 1991). In certain cases, this might call for further supplementation of nitrogen along with phosphorous to make up the requisite ratio. Further, given the complex nature of biofilms in drinking water biofilters, it is possible that several other parameters such potassium, magnesium, sulphates, manganese, etc. play an important role. These factors have not been studied in drinking water systems although the impacts of potassium and magnesium ions have been investigated in wastewater systems 
(Brdjanovic et al., 1996). Further research is needed to assess the effects of these parameters on drinking water biofiltration systems. 


\section{Materials and Methods}

This chapter provides a description of the pilot and lab scale setups used for the purposes of this study. It explains the methods used for biomass quantification and water quality analyses performed. Appendix A provides the design procedure for the lab scale setup.

\subsection{Pilot Scale Experiments (Preliminary Study Phase)}

A pilot-scale multi-stage filtration (MSF) system was used for the first phase of the study. The setup was located at the Britannia Water Treatment Plant (BWTP). Treatment occurred through two parallel trains. The MSF treated surface water from the Ottawa River.

Raw water from the Ottawa River entering the BWTP was used as the raw water supply for the pilot-scale MSF unit. Water characteristics at the intake of the pilot scale MSF system have been provided in Table 3.1 below. This table provides the parameters measured by BWTP at their raw water intake and the values measured at the intake to the pilot trailer.

Table 3.1: Pilot System Intake Characteristics

\begin{tabular}{|c|c|c|c|c|}
\hline \multirow{2}{*}{ Water Parameter } & \multicolumn{2}{|c|}{ Pilot Intake } & \multicolumn{2}{c|}{ BWTP Data } \\
\cline { 2 - 5 } & Average & Range & Average & Range \\
\hline Turbidity $(\mathrm{NTU})$ & 2.81 & $0.77-100$ & 3.38 & $1.22-10.47$ \\
\hline Temperature $\left({ }^{\circ} \mathrm{C}\right)$ & 13.5 & $1-20$ & 9.9 & $0.1-26.1$ \\
\hline Colour $(\mathrm{Pt}-\mathrm{Co})$ & 50.8 & $39-86$ & 42 & $32-61$ \\
\hline $\mathrm{pH}$ & - & - & 7.35 & $6.9-7.66$ \\
\hline $\mathrm{UVA}_{254}\left(\mathrm{~cm}^{-1}\right)$ & 0.42 & $0.29-1.12$ & 0.28 & $0.23-0.38$ \\
\hline DOC $(\mathrm{mg} / \mathrm{L})$ & 10.29 & $7.13-13.22$ & 7.2 & $6.7-8.1$ \\
\hline $\begin{array}{c}\text { Total Phosphorous } \\
(\mathrm{mg} / \mathrm{L})\end{array}$ & - & - & 0.013 & $0.011-0.014$ \\
\hline TKN (mg/L) & - & - & 0.31 & $0.29-0.33$ \\
\hline
\end{tabular}


As can be seen from Table 3.1, the source water to the trailer was phosphorous limited (TP $=13 \mu \mathrm{g} / \mathrm{L}$ ). This does not meet the bacterial $\mathrm{C}: \mathrm{N}: \mathrm{P}$ requirements to perform various metabolic functions based on the organic carbon content (LeChevallier et al., 1991).

The MSF system uses two parallel treatment trains with different processes. These include ozonation, upflow roughing filtration, and biofiltration. The design parameters for these are provided in Table 3.2 below.

Table 3.2: MSF Design Parameters (Black, 2013)

\begin{tabular}{|c|c|c|c|}
\hline & Design Parameter & Train 1 & Train 2 \\
\hline \multirow{3}{*}{$\begin{array}{c}\text { Ozone } \\
\text { Contactor }\end{array}$} & Diameter $(\mathrm{mm})$ & 150 & 150 \\
\cline { 2 - 4 } & Flow Rate $(\mathrm{L} / \mathrm{min})$ & $3-5^{*}$ & $3-5$ \\
\cline { 2 - 4 } & Volume $(\mathrm{L})$ & 24.7 & 24.7 \\
\cline { 2 - 4 } & Contact Time $(\mathrm{min})$ & $4.94-8.23$ & $4.94-8.23$ \\
\hline \multirow{4}{*}{ Roughing Filter } & Diameter $(\mathrm{mm})$ & 150 & - \\
\cline { 2 - 4 } & Flow Rate $(\mathrm{L} / \mathrm{min})$ & $0.5^{*}$ & - \\
\cline { 2 - 4 } & Surface Area $\left(\mathrm{m}^{2}\right)$ & 0.02 & - \\
\cline { 2 - 4 } & Surface Overflow Rate $(\mathrm{m} / \mathrm{hr})$ & 1.5 & - \\
\hline \multirow{4}{*}{ SSF } & Diameter $(\mathrm{mm})$ & 315 & - \\
\cline { 2 - 4 } & Flow Rate $(\mathrm{L} / \mathrm{min})$ & $0.5^{*}$ & - \\
\cline { 2 - 4 } & Surface Area $\left(\mathrm{m}^{2}\right)$ & 0.08 & - \\
\cline { 2 - 4 } & Surface Overflow Rate $(\mathrm{m} / \mathrm{hr})$ & 0.375 & - \\
\hline \multirow{4}{*}{ BAC Filter } & Diameter $(\mathrm{mm})$ & - & 315 \\
\cline { 2 - 4 } & Flow Rate $(\mathrm{L} / \mathrm{min})$ & - & $3-5$ \\
\cline { 2 - 4 } & Surface Area $\left(\mathrm{m}^{2}\right)$ & - & 0.08 \\
\cline { 2 - 4 } & Surface Overflow Rate $(\mathrm{m} / \mathrm{hr})$ & - & $2.25-3.75$ \\
\cline { 2 - 4 } & Media Volume $(\mathrm{L})$ & - & 0.039 \\
\cline { 2 - 4 } & EBCT $(\mathrm{min})$ & - & $7.8-12.99$ \\
\hline
\end{tabular}

*Flow from train 1 entered a peristaltic pump which allowed for flow control

Ozone generation occurs via an Azcozon SNOA-4 ozone generator by coronal discharge. Raw water enters the ozone generator and travels upwards. It then travels through the ozone 
contactors through a venturimeter. A titanium dioxide ozone destructor was present on both trains to remove residual ozone.

\subsubsection{Description of Train 1}

Raw water entered the first ozone contactor and was pumped to the roughing filter using a MasterFlex peristaltic pump. Rotameters were present to control the flow. Following the first contactor, the water entered a second column to provide additional residence time for ozonation to occur. The water then entered the roughing filter and finally the SSF. Three layers of underdrain material (gravel) were present at the bottom of the SSF to serve as support media. A HACH online turbidimeter was present at the effluent of the SSF to measure turbidity. Figure 3.1 below shows the processes involved in Train 1 .

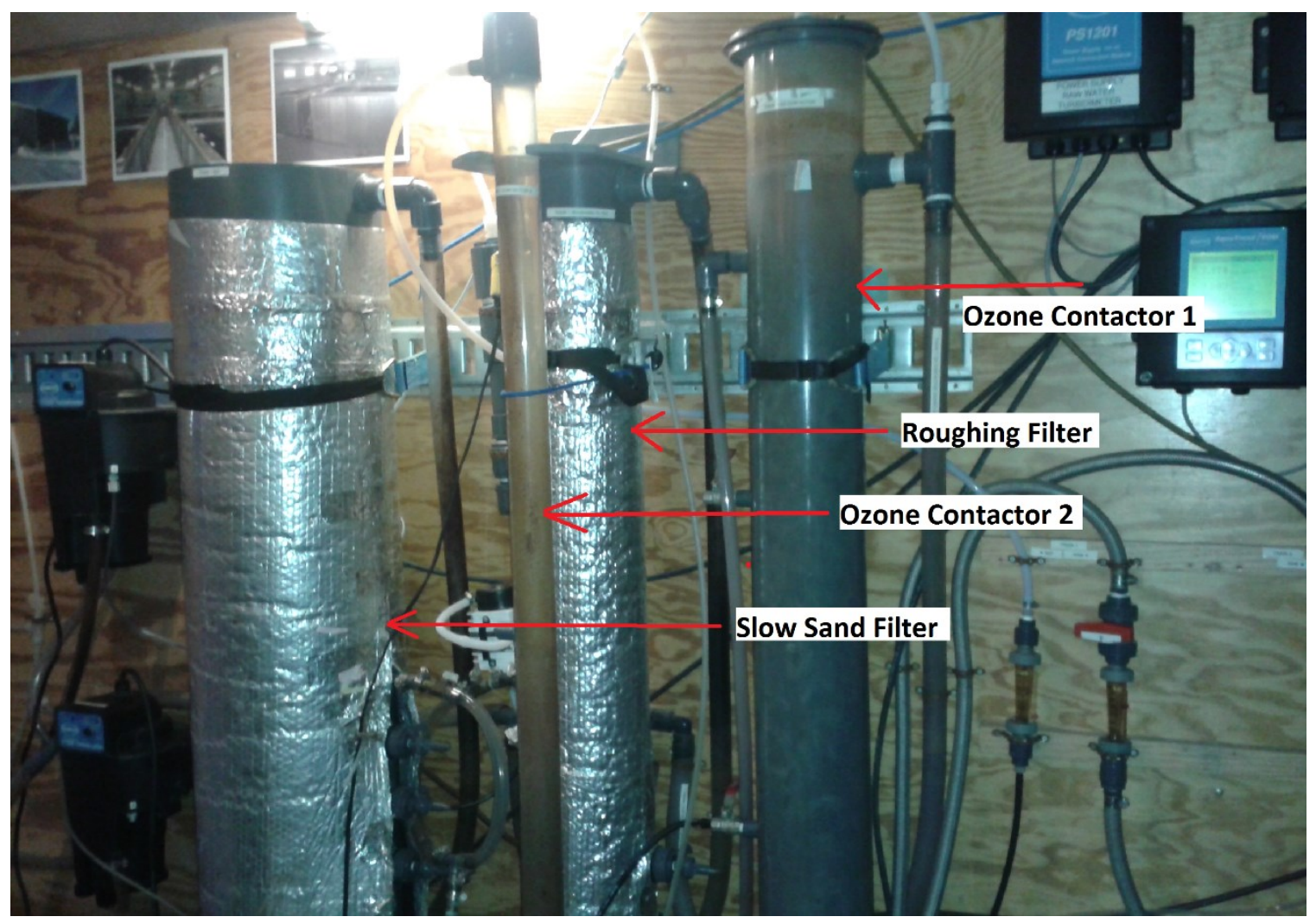

Figure 3.1: Train 1 processes 


\subsubsection{Description of Train 2}

Raw water entered the ozone contactor in Train 2 and following this was equally distributed to the two BAC filters. Train 2 differed from Train 1 in the absence of a roughing filter and a SSF. The SSF was replaced by two BAC filters in order to determine any differences in performance of the two processes. Three layers of gravel (supporting underdrain material) were present at the bottom of both BAC filters. As well, an online $\mathrm{HACH}$ turbidimeter was present to measure the turbidity of the combined effluent from the two BAC filters.

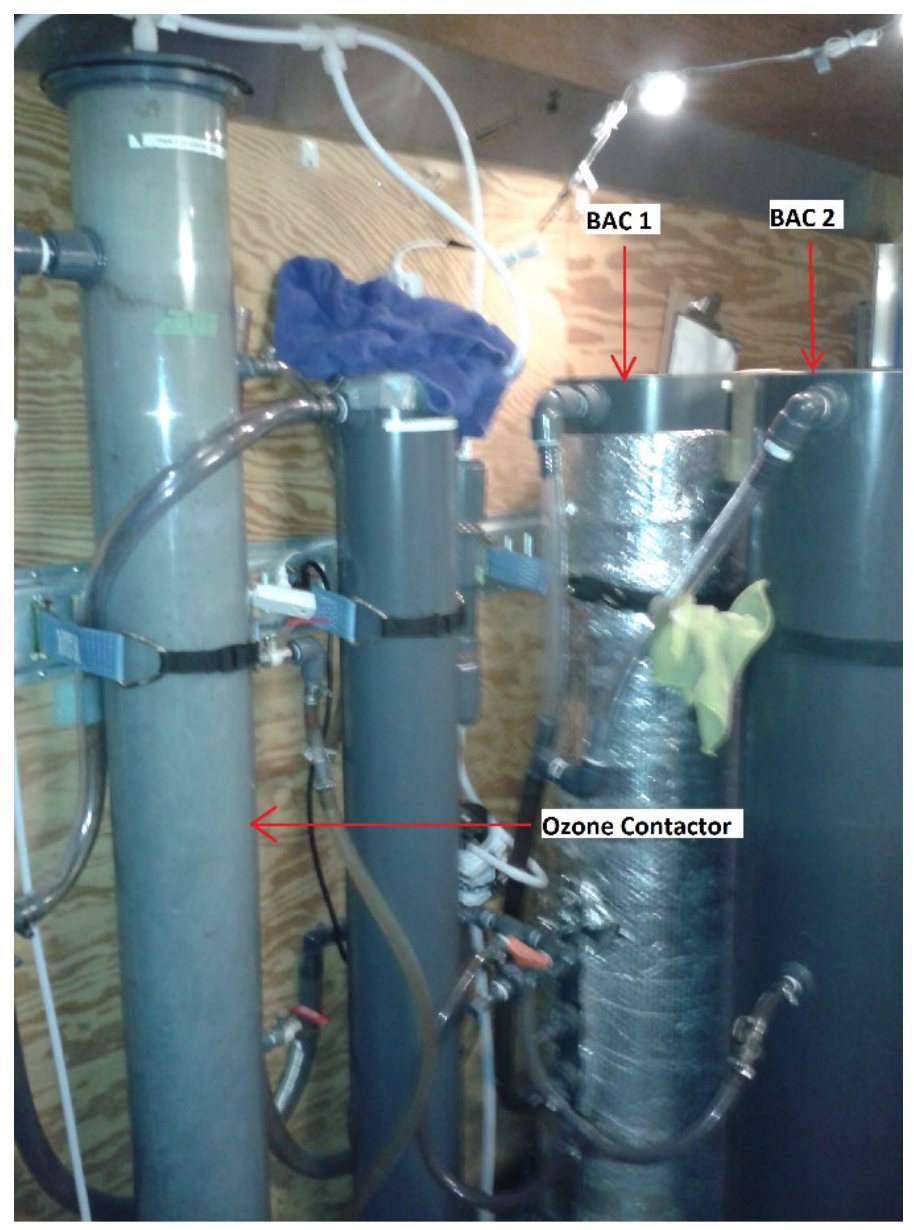

Figure 3.2: Train 2 Processes 


\subsubsection{Backwashing of Filters}

The BAC filters in Train 2 were backwashed once a week using a water only backwash. The backwash water was tap water which had a residual chlorine concentration of 0.17 $\mathrm{mg} / \mathrm{L}$.

The backwash procedure consisted of a low rate water wash at 18 LPM for 7 minutes followed by a high rate water wash at 24 LPM for 2 minutes and finally another low rate wash at 18 LPM for 7 minutes.

Due to the slow headloss buildup in the SSF, no cleaning was required over the course of this study.

\subsection{Lab Scale Experiments}

Four lab scale, dual media biofiltration columns were designed and setup at Carleton University. The columns were made of plexi-glass and mounted on a steel frame which was set on top of a drain. The columns were mounted using clamps and supported at the bottom on wooden planks.

Each column consisted of five sampling ports and one overflow port. A synthetic underdrain material was employed to prevent loss of media. Each column consisted of GAC and sand.

The bottom of each column had a $1 / 4$ inch opening on which further fittings could be attached. The configuration at the bottom of the columns initially consisted of a PVC union cross to which a ball valve was attached. One side of the union cross was used for backwashing procedures (plugged when not in use) while the other was plugged. 
Following the introduction of Phase 2 of experiments, the configuration for the bottom of the columns was altered. Instead of a PVC union cross and ball valve configuration, brass Swagelok fittings were employed. The new configuration consisted of a $1 / 4$ inch union cross attached to a $1 / 4$ inch tee fitting. One end of the union cross attached to the bottom of the columns while the other was attached to the tee. On the remaining ports, $1 / 4$ inch ball valves were attached. The two remaining ends of the tee fitting also had $1 / 4$ inch ball valves attached. This allowed for ease of use during backwash procedures, the introduction of air scour for backwashing and the introduction of effluent rotameters.

Rotameters (Cole Parmer) were attached to the effluent from the columns once the new fittings were put in place.

Design parameters for each column have been provided in Table 3.3.

Table 3.3: Filter and Media Specifications

\begin{tabular}{|c|c|}
\hline Parameter & Value \\
\hline Column Height $(\mathrm{mm})$ & 1250 \\
\hline Diameter (mm) & 50 \\
\hline $\begin{array}{c}\text { Flow Rate through Each Column } \\
(\mathrm{ml} / \mathrm{min})\end{array}$ & 100 \\
\hline Empty Bed Contact Time (EBCT) (min) & 15 \\
\hline GAC Bed Depth (mm) & 520 \\
\hline GAC Effective Size (mm) & 0.7 \\
\hline Sand Bed Depth (mm) & 180 \\
\hline Sand Effective Size (mm) & $0.35-0.55$ \\
\hline Synthetic Underdrain Depth (mm) & 15 \\
\hline
\end{tabular}




\subsubsection{Phases of Research}

Table 3.4 shows the phases of research for the lab scale study.

Table 3.4: Phases of Lab Scale Study

\begin{tabular}{|c|c|c|}
\hline $\begin{array}{c}\text { Study } \\
\text { Phase }\end{array}$ & Objective & Comments \\
\hline 1 & $\begin{array}{c}\text { Conditioning of three lab scale } \\
\text { dual media filters }\end{array}$ & $\begin{array}{c}\text { C:N:P ratio of 546:24:1 to mimic } \\
\text { phosphorous limited conditions from the } \\
\text { preliminary phase }\end{array}$ \\
\hline 2 & $\begin{array}{c}\text { Nitrogen (N), Phosphorous (P) } \\
\text { supplementation to alter C:N:P } \\
\text { ratio }\end{array}$ & $\begin{array}{c}\text { Addition of N, P to analyze impact of } \\
\text { different C:N:P ratios }\end{array}$ \\
\hline 3 & Potassium supplementation & $\begin{array}{c}\text { Addition of potassium (K) in addition to N } \\
\text { and P to assess the effects of K addition on } \\
\text { drinking water treatment }\end{array}$ \\
\hline
\end{tabular}

To check the reproducibility of results at cold temperatures $\left(<5^{\circ} \mathrm{C}\right)$, a chiller was installed in Phase 3. However, due to certain constraints, only an average of temperature of $11{ }^{\circ} \mathrm{C}$ was achievable. All filters and flow lines were insulated to prevent increase in water temperature. 


\subsubsection{Process Configuration}

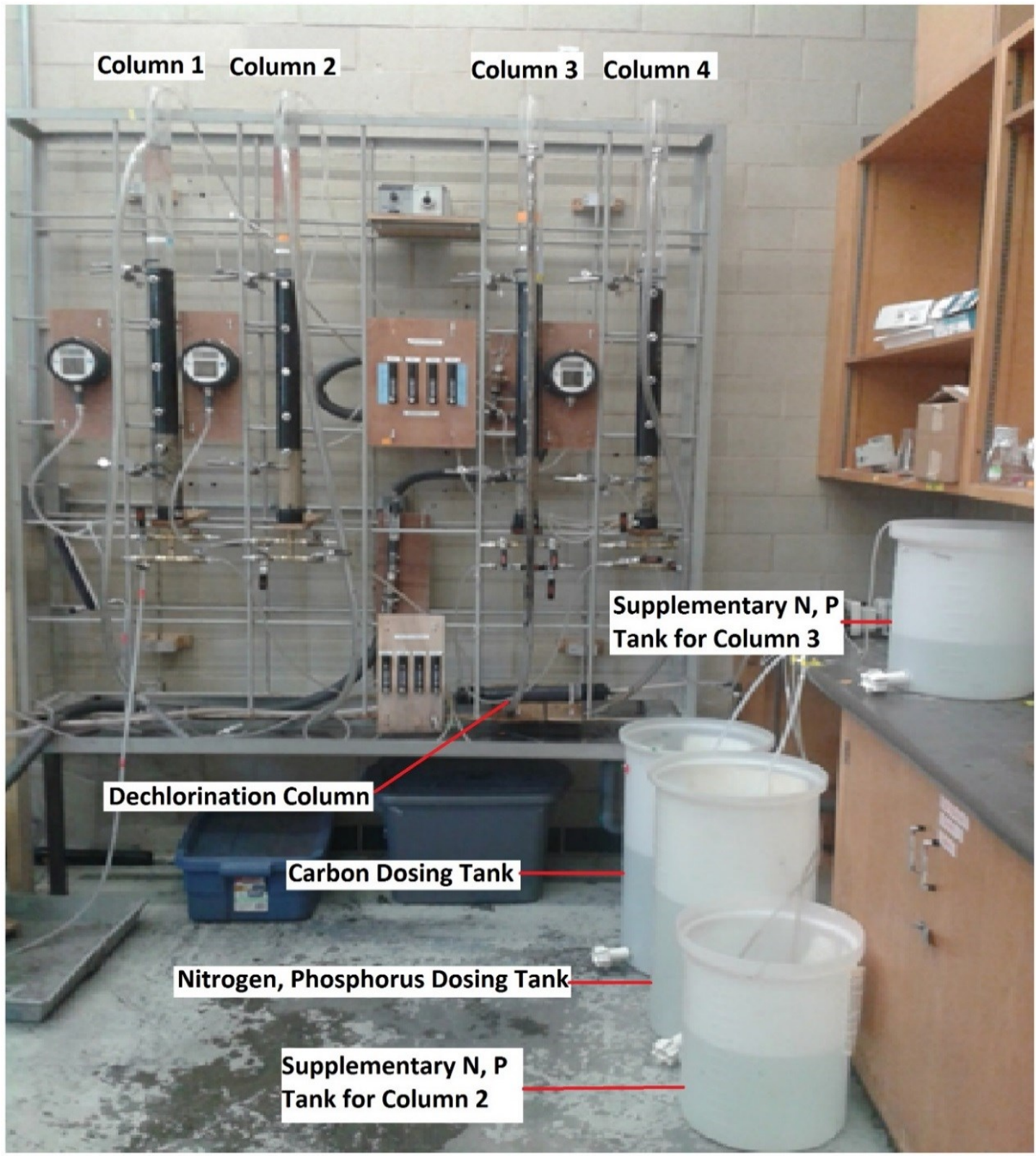

Figure 3.3: Lab scale biofilter setup

Figure 3.3 shows the biofiltration setup. The four columns were identical and each featured an influent and effluent line. During the conditioning phase of the experiments, the feed consisted of dechlorinated tap water mixed with dosing solutions to achieve a C:N:P ratio of 546:24:1(w/w). 
The dosing solutions were placed in two separate $50 \mathrm{~L}$ Nalgene heavy cylindrical containers. One tank contained the carbon dosing solution while the other contained nitrogen, phosphorous and micronutrients dosing solution. The tap water was made to pass through a $1 / 2$ inch brass check valve (McMaster Carr) and into a flow meter (McMaster Carr). The two dosing solutions were then dosed into the line with the help of a peristaltic pump (Masterflex, model 7519-15), Masterflex tubing (LS-14) and cartridges. An in-line static mixer (McMaster Carr) allowed for mixing. Following this, the flow would enter a manifold (McMaster Carr) from where it would be split into four rotameters (Cole Parmer) which would serve as the influent to each column.

During the second phase of experiments, columns 2 and 3 began receiving supplementary nitrogen and phosphorous. For this purpose, two Nalgene cylindrical tanks were used. One had a capacity of $26 \mathrm{~L}$ and was used to dose column 2 while the other had a capacity of 18 $\mathrm{L}$ and was used to dose column 3 . The dosing was carried out by using the same peristaltic pump as before (Masterflex, model 7519-15) and the tubings were placed directly into the columns thereby allowing the solutions to drip into them.

For the purposes of these experiments, columns 2, 3 and 4 were used. Column 1 was in use by another graduate student.

\subsubsection{Backwash Procedures}

For Phase 1, backwash consisted of a water only backwash. This was altered to an air scour assisted collapse pulsing backwash for Phase 2 and 3. The details for the backwash procedure have been provided in Table 3.5. 
Table 3.5: Backwash Procedures for Phase 1, 2 and 3

\begin{tabular}{|c|c|c|}
\hline Phase & Backwash Procedure & Comments \\
\hline \multirow{3}{*}{ Phase 1} & Water Only Backwash & \multirow{3}{*}{$\begin{array}{c}30 \% \mathrm{GAC} B e c \\
\text { Expansion }\end{array}$} \\
\hline & Duration $=10 \mathrm{~min}$ & \\
\hline & Backwash Velocity, $\mathrm{v}_{\mathrm{b}}=30 \mathrm{~m} / \mathrm{hr}$ & \\
\hline \multirow{3}{*}{ Phase 2, 3} & $\begin{array}{c}\text { Air } / \text { Water Flush }=6 \mathrm{~min} \\
\text { vair }=72 \mathrm{~m} / \mathrm{hr} ; \mathrm{v}_{\text {water }}=12 \mathrm{~m} / \mathrm{hr}\end{array}$ & - \\
\hline & $\begin{array}{l}\text { High Rate Water Only Flush }=2 \mathrm{~min} \\
\text { Backwash Velocity, } \mathrm{v}_{\mathrm{b}}=30 \mathrm{~m} / \mathrm{hr}\end{array}$ & $\begin{array}{l}30 \% \text { GAC Bed } \\
\text { Expansion }\end{array}$ \\
\hline & $\begin{array}{l}\text { Low Rate Water Only Flush }=2 \mathrm{~min} \\
\qquad \mathrm{v}_{\mathrm{b}}=10.5 \mathrm{~m} / \mathrm{hr}\end{array}$ & - \\
\hline
\end{tabular}

\subsection{Analytical Methods}

A summary of parameters analyzed and their sampling frequency has been provided in

Table 3.6. The table also indicates if the specific parameter was analyzed at the pilot or lab scale study respectively. The analysis of some parameters began at different phases at the lab scale. This has also been indicated. 
Table 3.6: Parameter Sampling Frequency

\begin{tabular}{|c|c|c|c|c|}
\hline Parameter & $\begin{array}{l}\text { Sampling } \\
\text { Frequency }\end{array}$ & $\begin{array}{l}\text { Analyzed } \\
\text { at Pilot } \\
\text { Scale Study }\end{array}$ & $\begin{array}{c}\text { Analyzed } \\
\text { in Lab } \\
\text { Scale Study }\end{array}$ & Comments \\
\hline $\begin{array}{c}\text { Dissolved } \\
\text { Organic Carbon }\end{array}$ & $\begin{array}{l}\text { 3/week for both } \\
\text { Pilot and Lab } \\
\text { Scale }\end{array}$ & Yes & Yes & $\begin{array}{c}\text { Analyzed } \\
\text { throughout each } \\
\text { study }\end{array}$ \\
\hline $\begin{array}{l}\text { Ultraviolet } \\
\text { Absorbance }\end{array}$ & $\begin{array}{l}\text { 3/week for both } \\
\text { Pilot and Lab } \\
\text { Scale }\end{array}$ & Yes & Yes & $\begin{array}{c}\text { Analyzed } \\
\text { throughout each } \\
\text { study }\end{array}$ \\
\hline Total Nitrogen & 2/week & No & Yes & Started in Phase 2 \\
\hline Phosphorous & 2/week & No & Yes & Started in Phase 2 \\
\hline Potassium & 2/week & No & Yes & Started in Phase 3 \\
\hline $\begin{array}{l}\text { Adenosine Tri } \\
\text { Phosphate } \\
\text { Method (Biomass } \\
\text { Quantification) }\end{array}$ & $\begin{array}{l}\text { 1/week for both } \\
\text { Pilot and Lab } \\
\text { Scale }\end{array}$ & Yes & Yes & $\begin{array}{c}\text { Started in Phase } 3 \\
\text { (Lab Scale) }\end{array}$ \\
\hline $\begin{array}{l}\text { Phospholipid } \\
\text { Method (Biomass } \\
\text { Quantification) }\end{array}$ & 2/week & No & Yes & Started in Phase 2 \\
\hline Temperature, $\mathrm{pH}$ & Daily & Yes & Yes & $\begin{array}{c}\text { Analyzed } \\
\text { throughout each } \\
\text { study }\end{array}$ \\
\hline Turbidity & $\begin{array}{l}\text { Daily at Pilot } \\
\text { Scale } \\
\text { 3/week at Lab } \\
\text { Scale }\end{array}$ & Yes & Yes & $\begin{array}{c}\text { Analyzed } \\
\text { throughout each } \\
\text { study }\end{array}$ \\
\hline
\end{tabular}

\subsubsection{Glassware and Sample Storage}

All water samples were stored in clean, amber glass bottles. Prior to sample storage, the bottles were placed in a $10 \% \mathrm{HCl}$ solution overnight. Following this, bottles were thoroughly rinsed with DI water (obtained using a Milli-Q purification system), wrapped in aluminium foil and baked in an oven at $400{ }^{\circ} \mathrm{C}$ for a minimum of 40 minutes. All water samples were stored in these glass bottles at $4{ }^{\circ} \mathrm{C}$ and were analyzed within a week of storage. 


\subsubsection{Dosing Solution Preparation (Lab Scale)}

Dosing solutions were prepared using distilled water. Stock solutions were prepared with the requisite chemicals in $1 \mathrm{~L}$ volumetric flasks which were thoroughly rinsed with phosphate free soap and DI water. The stock solutions were then allowed to mix on a stir plate with a magnetic stirrer at least overnight. Following this, stock solutions were placed in their respective tanks, filled up to the mark and mixed using a stand mixer. The stand mixer operated at $350 \mathrm{rpm}$ for a minimum of 30 minutes.

Synthetic raw water make up for the lab scale biofilter setup has been provided in Table 3.7 and shows the chemicals used to prepare the dosing solutions.

Table 3.7: Synthetic Raw Water Make Up

\begin{tabular}{|c|c|c|c|c|}
\hline Phase & Carbon Source & $\begin{array}{c}\text { Nitrogen, Phosphorous } \\
\text { Source }\end{array}$ & $\begin{array}{l}\text { Potassium } \\
\text { Source }\end{array}$ & $\begin{array}{l}C: N: P \\
(w / w)\end{array}$ \\
\hline 1 & $\begin{array}{l}\text { Glyoxal, Acetic } \\
\text { Acid, Formic Acid }\end{array}$ & $\begin{array}{l}\text { Aluminium Nitrate, } \\
\text { Potassium Dihydrogen } \\
\text { Phosphate }\end{array}$ & - & $\begin{array}{l}546: 24: 1 \\
\quad(\text { All } \\
\text { Columns) }\end{array}$ \\
\hline \multirow{3}{*}{2} & \multirow{3}{*}{$\begin{array}{l}\text { Glyoxal, Acetic } \\
\text { Acid, Formic Acid }\end{array}$} & \multirow{3}{*}{$\begin{array}{c}\text { Aluminium Nitrate, } \\
\text { Sodium Nitrate } \\
\text { Potassium Dihydrogen } \\
\text { Phosphate }\end{array}$} & & $25: 5: 1$ \\
\hline & & & & 100:10:1 \\
\hline & & & & $546: 24: 1$ \\
\hline \multirow{3}{*}{3} & \multirow{3}{*}{$\begin{array}{l}\text { Glyoxal, Acetic } \\
\text { Acid, Formic Acid }\end{array}$} & \multirow{3}{*}{$\begin{array}{c}\text { Aluminium Nitrate, } \\
\text { Sodium Nitrate, } \\
\text { Potassium Dihydrogen } \\
\text { Phosphate }\end{array}$} & \multirow{3}{*}{$\begin{array}{l}\text { Potassium } \\
\text { Sulphate } \\
\text { for } 25: 5: 1 \\
\text { column }\end{array}$} & $25: 5: 1(+\mathrm{K})$ \\
\hline & & & & 100:10:1 \\
\hline & & & & $546: 24: 1$ \\
\hline
\end{tabular}

\subsubsection{Total Organic Carbon (TOC)/Dissolved Organic Carbon (DOC)}

TOC and DOC were measured in accordance with the Persulfate Ultraviolet Oxidation Method in Standard Methods 5310C (APHA, 2012). 
DOC analysis was performed using a SHIMADZU TOC-VCPH/ CPN total organic carbon analyzer. Prior to DOC analysis, samples were filtered through a $0.45 \mu \mathrm{m}$ filter (Millipore). Filtered samples were stored in $50 \mathrm{ml}$ glass vials that were cleaned as per the procedure provided in Section 3.3.1.

\subsubsection{Ultraviolet Absorbance (UVA) and Specific Ultraviolet Absorbance (SUVA)}

Prior to UVA analysis, samples were filtered through a $0.45 \mu \mathrm{m}$ filter (Millipore) and were stored in $50 \mathrm{ml}$ glass vials that were cleaned as per the procedure described in Section 3.3.1. Ultraviolet absorbance at $254 \mathrm{~nm}$ was measured in accordance with Standard Methods 5910B (APHA, 2012). Samples were placed in a quartz cuvette (1 cm in length) and a scan was conducted from $200-400 \mathrm{~nm}$ using a UV visible Spectrophotmeter (Spectronic Unicam). The UV absorbance value at $254 \mathrm{~nm}$ was then recorded.

Specific ultraviolet absorbance (SUVA) was calculated as the UV absorbance values at $254 \mathrm{~nm}$ normalized by the DOC concentration.

$$
S U V A=\frac{U V A_{254}}{D O C} \times 100\left(\frac{L}{m g . m}\right)
$$

Where $\mathrm{UVA}_{254}$ is the UV absorbance at $254 \mathrm{~nm}\left(\mathrm{~cm}^{-1}\right)$ and DOC is the dissolved organic carbon concentration $(\mathrm{mg} / \mathrm{L})$.

\subsubsection{Total Nitrogen (TN)}

Total nitrogen analysis was carried out using a SHIMADZU TNM-1 total nitrogen analyzer. Influent total nitrogen samples were drawn from the top sampling port of the columns using a syringe that had been soaked in a phosphate free soap solution overnight and rinsed with DI water. Effluent samples were collected from the filter effluents. Samples 
were stored in $50 \mathrm{ml}$ glass vials that were cleaned as per the procedure described in Section 3.3.1.

\subsubsection{Phosphorous}

The PhosVer 3 method (\#8190) was used to analyze phosphorous with a HACH DR2800 spectrophotometer. This method can detect 0.02 to $1.10 \mathrm{mg} \mathrm{P} / \mathrm{L}$. Influent phosphorous samples were drawn from the top sampling port of the columns using a syringe that had been soaked in a phosphate free soap solution overnight and rinsed with DI water. Effluent samples were collected from the filter effluents. Samples were stored in $50 \mathrm{ml}$ glass vials that were cleaned as per the procedure described in Section 3.3.1.

\subsubsection{Potassium}

Potassium was analyzed using the Tetraphenylborate method (\#8049) and a HACH DR2800 spectrophotometer. This method can detect potassium concentrations in the range of $0.1-7 \mathrm{mg} \mathrm{K} / \mathrm{L}$. Influent potassium samples were drawn from the top sampling port of the columns using a syringe that had been soaked in a phosphate free soap solution overnight and rinsed with DI water. Effluent samples were collected from the filter effluents. Samples were stored in $50 \mathrm{ml}$ glass vials that were cleaned as per the procedure described in Section 3.3.1.

\subsubsection{Adenosine Tri-Phosphate (ATP) Method for Biomass Quantification}

Approximately $1 \mathrm{~g}$ of media was drawn for the top and middle of each column after they were taken offline. The Deposit Surface Analysis Test (LuminUltra Technologies Ltd., NB) was used. Relative lights units (RLU) were measured using a Luminometer 
(PhotonMaster) and was converted to pg ATP/g media using the formula provided by the company.

\subsubsection{Phospholipid Method for Biomass Quantification}

Biomass extraction using the phospholipid procedure consisted of three steps: extraction, digestion and quantification based on a method proposed by Wang et al. (1995). The flow chart for this process has been provided below.

\section{Extraction}

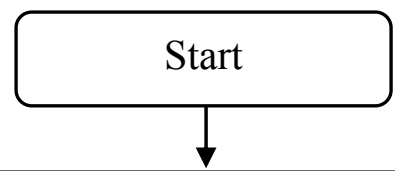

Transfer between 0.1 and $1 \mathrm{~g}$ of media to a 20 $\mathrm{mL}$ EPA vial (the amount of sampled media must yield an amount of lipid phosphate $\leq 40$ nmol)

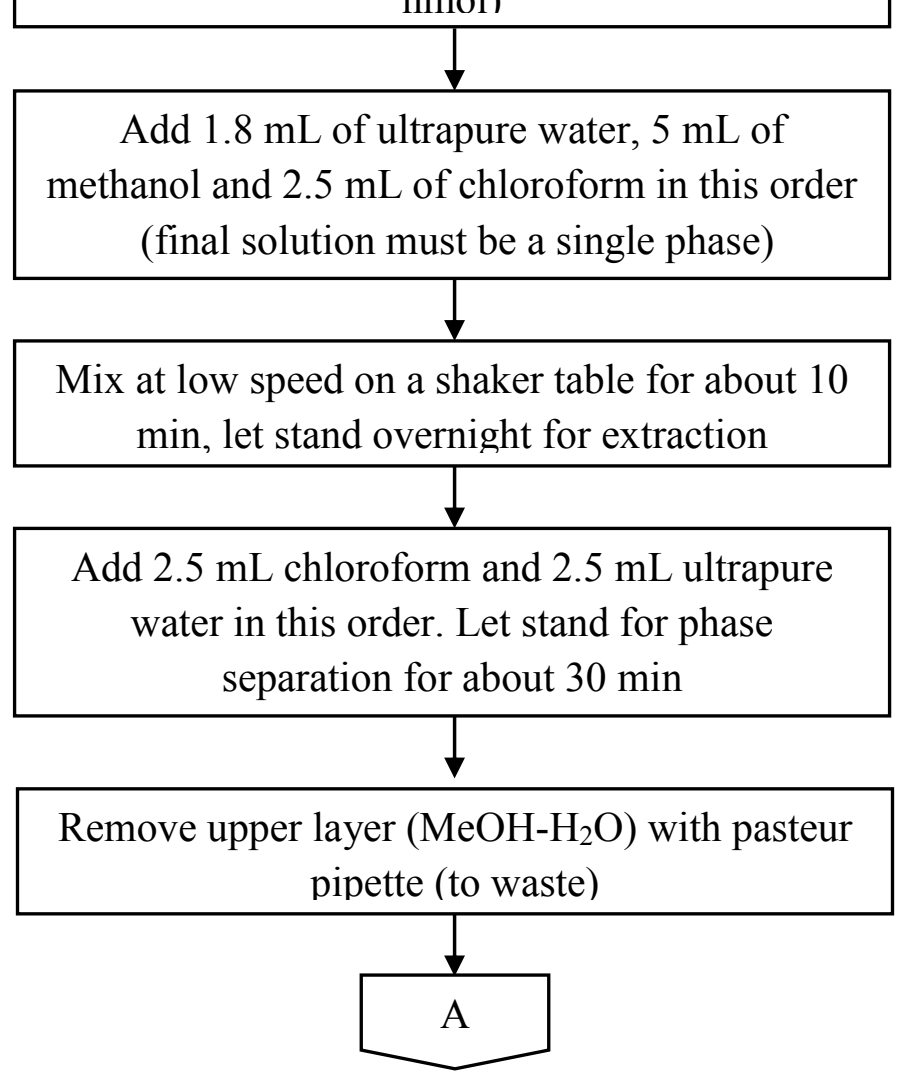




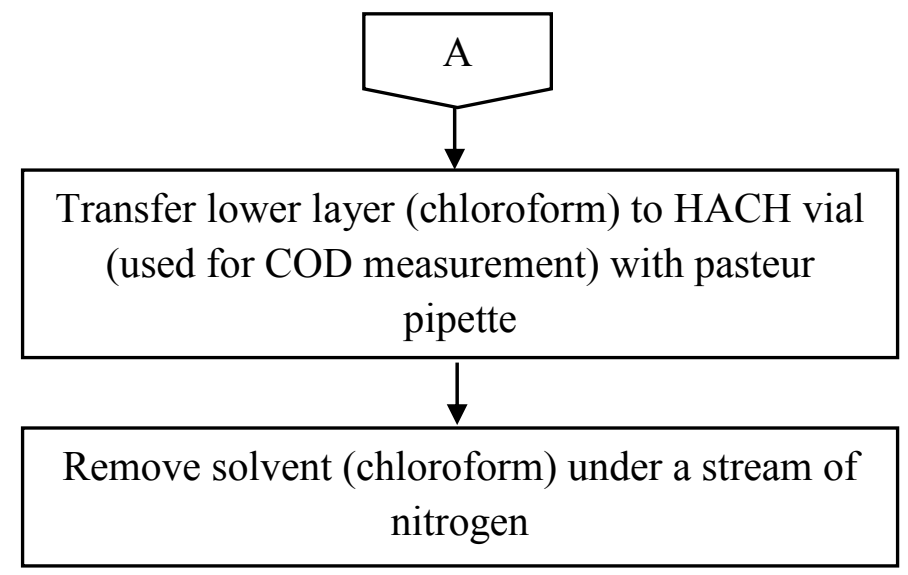

\section{Digestion}

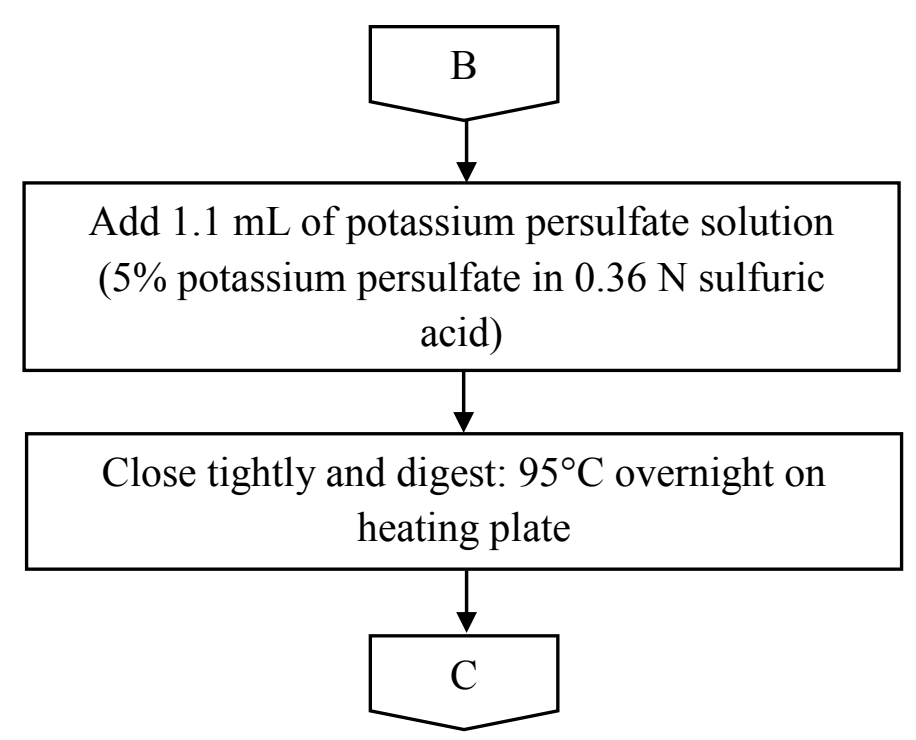

\section{Continued on next page}




\section{Quantification}

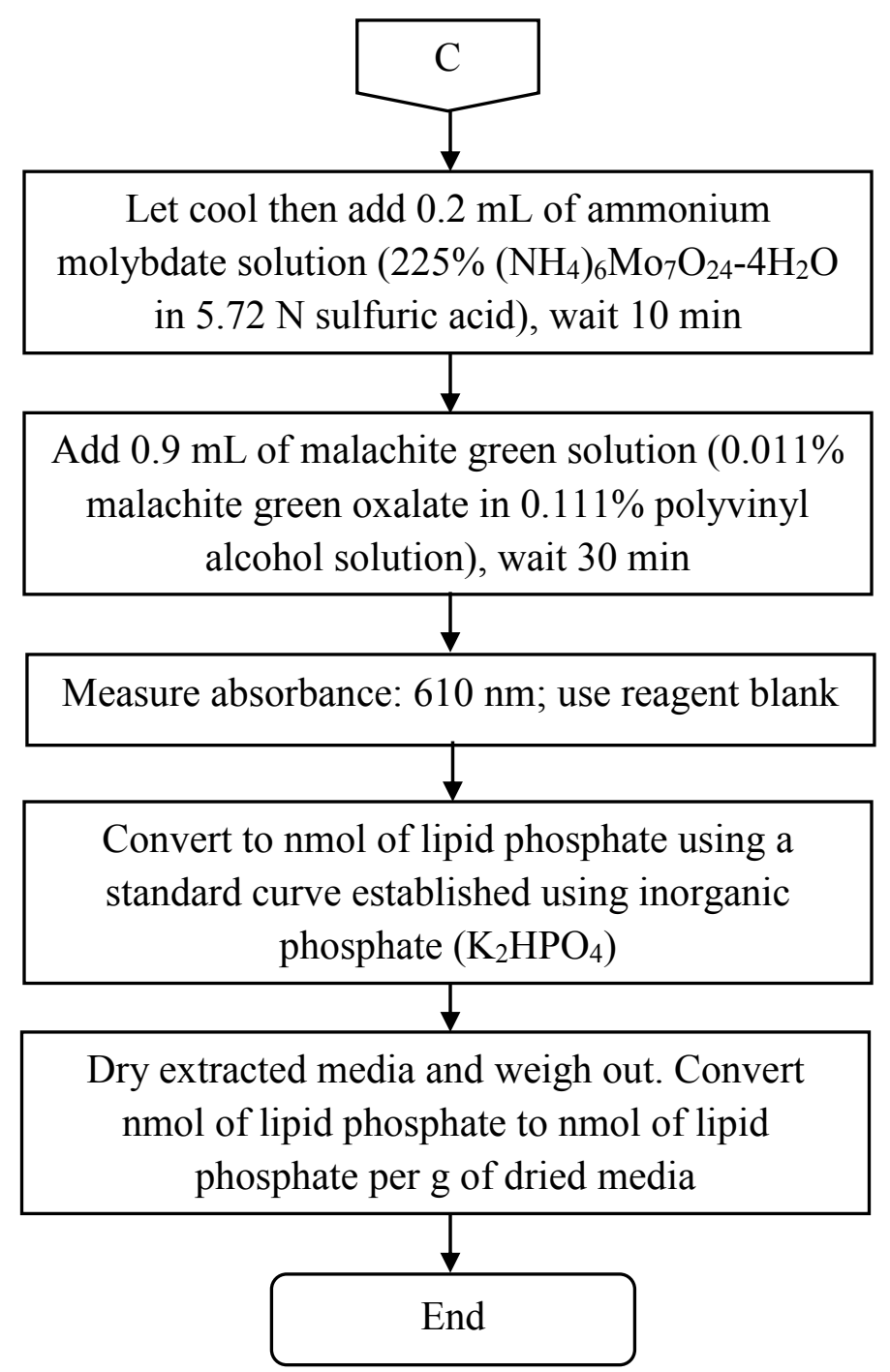

\subsubsection{Temperature, $\mathrm{pH}$}

Temperature and $\mathrm{pH}$ were monitored using a $\mathrm{pH}$ probe (Thermo Scientific ORION 087003). A three-point $\mathrm{pH}$ calibration was carried out at $\mathrm{pH} 4,7$ and 10. 


\subsubsection{Turbidity}

For the preliminary set of experiments at BWTP, in-line low range trubidimeters $(\mathrm{HACH}$ PS1201) were used to assess the turbidity of influent and effluent of Train 1 and Train 2.

For the lab scale experiments, a portable $\mathrm{HACH}$ trubidimeter was used to analyze influent and effluent turbidity values.

\subsubsection{Statistical and Data Analysis}

Statistical analysis was performed in the form of a paired t-test ( $95 \%$ confidence interval) unless stated otherwise. Average, maximum, minimum and standard deviations of sample range were determined. Error bars in the figures represent standard deviation. 


\section{Preliminary Investigation Results}

A preliminary pilot scale study was conducted at BWTP, Ottawa, ON, Canada to understand the effects of nutrient limitation on biofilter performance. BWTP treated raw water from the Ottawa River. The following raw water data was obtained for the river by BWTP:

Table 4.1: Raw water quality of Ottawa River

\begin{tabular}{|c|c|}
\hline Parameter & Average Concentration (mg/L) \\
\hline Aluminium & 0.18 \\
\hline Calcium & 8.00 \\
\hline Iron & 0.23 \\
\hline Manganese & 0.010 \\
\hline Magnesium & 2.10 \\
\hline Sodium & 3.10 \\
\hline Alkalinity (as CaCO 3 ) & 24.30 \\
\hline Carbon (as DOC) & 7.10 \\
\hline Nitrogen (as TKN) & 0.31 \\
\hline Phosphorous (as TP) & 0.013 \\
\hline
\end{tabular}

Based on the above data, the C:N:P ratio was calculated to be $546: 24: 1$ on a w/w basis. Typically, heterotrophic bacteria require a C:N:P of 100:10:1 on a mol basis (LeChevallier et al., 1991) which corresponds to a ratio of 39:4.5:1 on a w/w basis. Thus, the source water observed here was phosphorous limited.

The objective of this study was to determine the impacts of nutrient limited conditions on biofiltration processes for drinking water treatment. Once a preliminary set of results could be established, a more controlled set of experiments could take place on a lab scale biofiltration set up (Chapter 5). This preliminary study phase lasted from September 2013 - December 2013. 


\subsection{DOC Removal}

Several changes were made to the system over the course of the study phase. These changes have been described below and their impacts on organics removal have been discussed. Figure 4.1 below shows the \%DOC removal trend observed for Train 1 and Train 2 over the course of the study period

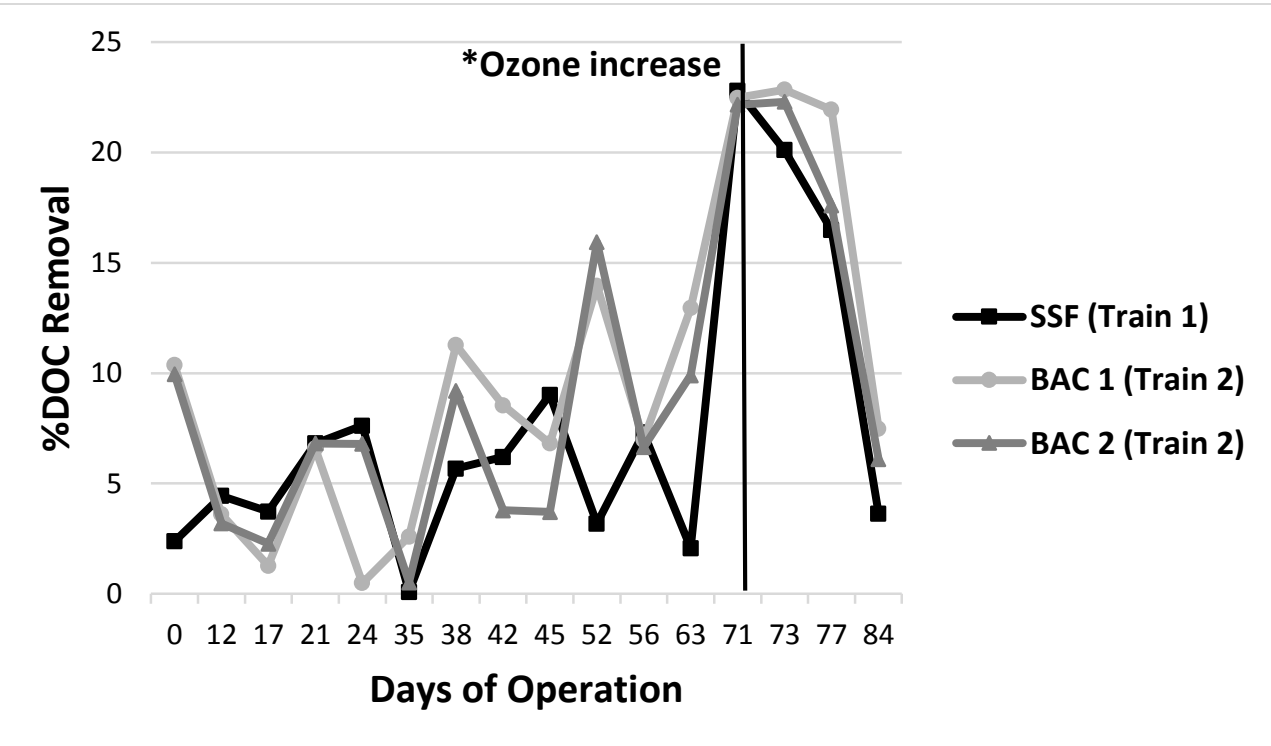

Figure 4.1: \%DOC removal vs time for Train 1, Train 2

*Ozone dosage increased from $1.55 \mathrm{mg} \mathrm{O} / \mathrm{mg}$ DOC to $3 \mathrm{mg} \mathrm{O} / \mathrm{mg} \mathrm{DOC}$

As can be seen from Figure 4.1, the two BAC filters operating in parallel performed similarly (as was expected). However, significant variations in DOC removal were observed throughout the course of the study. Ideally, a steady state would be reached wherein DOC removals as a result of biodegradation become relatively constant over a period of time (Simpson, 2008). The fluctuations in DOC removal observed here suggest that nutrient limited conditions may not provide ideal conditions for achieving optimal DOC removal. As well, it could indicate that the water only backwash being employed for the two BAC filters was perhaps inadequate and the residual chlorine concentration in the 
tap water used to backwash the BAC filters is perhaps undesirable. Indeed, previous research has indicated that chlorine free backwashes showed higher glyoxal and methyl glyoxal removal ( $76 \%$ and $35 \%$ respectively) when compared to backwashes with water that had a chlorine dose between $2.5-3 \mathrm{mg} \mathrm{Cl} / \mathrm{L}$ (Miltner et al., 1995).

Prior to day 63, the two BAC filters contained granular activated carbon only. Following this, sand was added in order to replicate a dual media biofiltration column. Sand was added to increase the head in the two GAC filters by $4 \mathrm{~cm}$. This resulted in a slight increase in EBCT from 10.25 minutes to 11 minutes.

Prior to day 68 , the ozone dosage was kept relatively constant at $1.55 \mathrm{mg} \mathrm{O}_{3} / \mathrm{mg}$ DOC. Ozone dosage could not be increased beyond this value as the ozone generator being used in this study experienced leaks. It was believed that the primary source of the leak was the venturimeter on the Train 2 side. Following replacement of the venturimeter, the ozone dosage was increased to $3 \mathrm{mg} \mathrm{O} / \mathrm{mg}$ DOC. This was done with the hope that an improvement in organic removal performance would be observed.

Following this increase and the addition of sand in Train 2, a significant improvement in DOC removal was observed for both Train 1 and 2 from day 63 to day 73. However, despite changing the venturimeter, a residual of $2.17 \mathrm{mg} \mathrm{O} / / \mathrm{L}$ and $1.8 \mathrm{mg} \mathrm{O}_{3} / \mathrm{L}$ was measured at the two BAC filters and SSF respectively indicating ozone had leaked into the system. Following this, DOC removal dropped significantly for the SSF, BAC 1 and BAC 2; with removals as low as $3.6 \%, 7.5 \%$ and $6.1 \%$ being recorded for the SSF and BAC $1, \mathrm{BAC} 2$ respectively. 
It should be noted as well that the water temperature over the course of this study ranged from $1{ }^{\circ} \mathrm{C}$ to $20^{\circ} \mathrm{C}$. Water temperatures began to reduce around day 35 (water temperature dropped from $20^{\circ} \mathrm{C}$ to $10{ }^{\circ} \mathrm{C}$ ) and continued to drop thereafter; reaching a low of $1{ }^{\circ} \mathrm{C}$. Temperature has been found play a significant role in biofilter performance for organics removal (Moll et al., 1999; Liu et al., 2001; Emelko et al., 2006). As well, ATP analysis of biomass shows a sharp reduction in top of the filter biomass concentrations at this time.

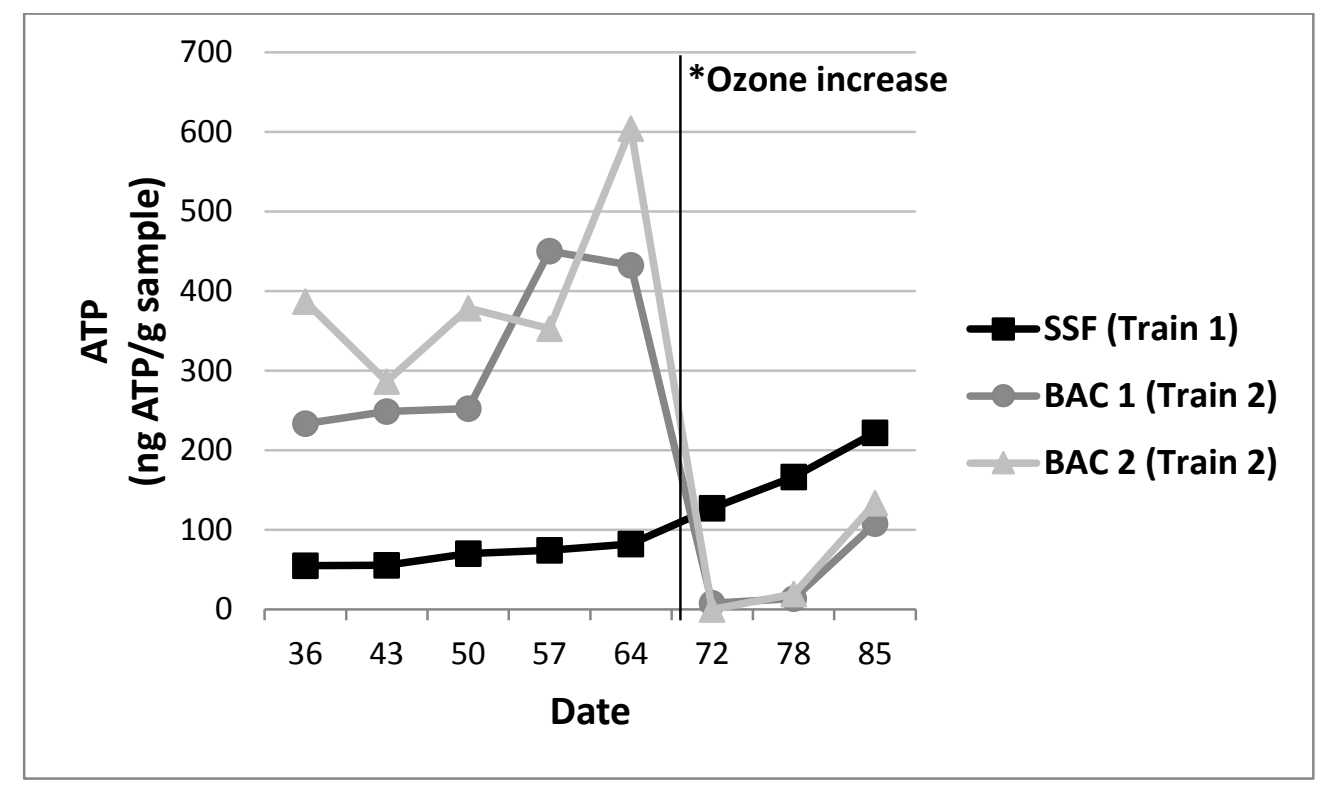

Figure 4.2: Top of the filter ATP concentrations for Train 1 and 2 *Ozone dosage increased from $1.55 \mathrm{mg} \mathrm{O}_{3} / \mathrm{mg} \mathrm{DOC}$ to $3 \mathrm{mg} \mathrm{O} / \mathrm{mg} \mathrm{DOC}$

Top of the filter ATP analysis was carried out for the media SSF and the two BAC columns in an attempt to quantify microbial growth. ATP can serve as an indication of bacterial activity and biomass as it is the primary energy carrier in living organisms (Caprita et al., 2006). Figure 4.2 shows the ATP concentrations at the top of the SSF and the two BAC filters. 
As can be seen from the figure, the high ozone residual resulted in a drastic decrease in ATP concentrations for BAC 1 and BAC 2. However, a similar decrease was not observed for the SSF. It is possible that the higher ozone residual of $2.17 \mathrm{mg} \mathrm{O} / \mathrm{L}$ experienced by Train 2 was more detrimental to biomass growth. In comparison, the SSF saw a residual of $1.8 \mathrm{mg} \mathrm{O}_{3} / \mathrm{L}$.

Prior to the ozone increase (day 68), the ATP concentrations in the two BAC filters were statistically higher than the SSF $(p=0.001, \alpha=0.05)$. Similar results were obtained MagicKnezev and van der Kooij (2004). It was observed that SSFs showed ATP concentrations of 18 - $93 \mathrm{ng}$ ATP.cm ${ }^{-3}$ whereas ATP concentrations in GAC filters ranged from $24-5067$ ng ATP.cm ${ }^{-3}$. ATP concentrations in the two BAC filters were slightly higher than what has been reported previously (Boon et al., 2011, Velten et al., 2011).

Thus, based on the above observations, several factors could have contributed to the overall reduction in DOC removal. It is believed that the ozone residual destroyed active biomass growth on the SSF, BAC 1 and BAC 2. As well, the significant reduction in water temperature in conjunction with the destruction of the active biofilm may have played a role.

Average DOC removals over the course of the study for SSF, BAC 1 and BAC 2 were $7.85 \%, 10.29 \%$ and $8.38 \%$ respectively. Other studies on pilot scale setups have shown comparable removals for $\mathrm{O}_{3} / \mathrm{BAC}$ processes. For instance, Kaarela et al (2014) found TOC removals of approximately $9 \%$ for activated carbon filters with pre-ozonation dosage between $0.3-0.4 \mathrm{mg} \mathrm{O}_{3} / \mathrm{mg}$ TOC. Matilainen et al (2010) found TOC removals of $13 \%$ for two activated carbon filters in series receiving an ozone dose of $0.4-1.5 \mathrm{~g} \mathrm{O}_{3} / \mathrm{dm}^{3}$. 
The SSF removal obtained here is lower than what has been observed in other studies. Yordanov et al. (1996) observed TOC removals of 28\% with pre-ozonation. Campos et al (2002) observed DOC removals in the range of $23-25 \%$ for slow sand filters receiving pre-ozonation.

A t-test was conducted $(\alpha=0.05)$ to determine if any statistical differences were observed in DOC removals between Train 1 and Train 2. \%DOC removal from BAC 1 and BAC 2 were averaged to calculate the overall removal from Train 2. The results are presented below in Table 4.2

Table 4.2: t-test analysis on \%DOC removal between Train 1 and $2(n=17)$

\begin{tabular}{|c|c|c|}
\hline Train Number & $\begin{array}{c}\text { Average \%DOC Removal } \pm \\
\text { SD }\end{array}$ & p-Value \\
\hline Train 1 & $7.85 \pm 6.45$ & 0.26 \\
\hline Train 2 & $9.33 \pm 6.79$ & \\
\hline
\end{tabular}

As seen in Table 4.2, no statistical differences were observed between the two trains. Thus, both trains exhibited similar performances in terms of DOC removal. As well, statistical analysis conducted on the performance of the two BAC filters in Train $2(\alpha=0.05)$ indicated no significant differences $(\mathrm{p}=0.22)$.

\subsection{UVA and SUVA removal}

High SUVA values indicate a high aromatic NOM fraction (Weishaar et al., 2003). SUVA values of NOM from natural surface waters have been reported in the range of $2.4-4.3$ L. $\mathrm{mg}^{-1} \mathrm{~m}^{-1}$ (Krasner et al., 1996). Table 4.3 shows the average influent and effluent UVA and SUVA values in the raw water and effluent for the two trains. 
Table 4.3: Average influent and effluent values of UVA and SUVA for Train 1 and 2

\begin{tabular}{|c|c|c|c|c|}
\hline & \multicolumn{2}{|c|}{$\mathrm{UVA}_{254}\left(\mathrm{~cm}^{-1}\right)$} & \multicolumn{2}{|c|}{ SUVA254 (L.mg-1 m' } \\
\hline Train & $\begin{array}{c}\text { Influent } \\
\text { Average } \pm \text { SD }\end{array}$ & $\begin{array}{c}\text { Effluent } \\
\text { Average } \pm \text { SD }\end{array}$ & $\begin{array}{c}\text { Influent } \\
\text { Average } \pm \text { SD }\end{array}$ & $\begin{array}{c}\text { Effluent } \\
\text { Average } \pm \text { SD }\end{array}$ \\
\hline $\begin{array}{c}\text { SSF } \\
\text { (Train 1) }\end{array}$ & $0.42 \pm 0.28$ & $0.36 \pm 0.28$ & $4.03 \pm 2.96$ & $3.88 \pm 3.48$ \\
\hline $\begin{array}{c}\text { BAC 1 } \\
\text { (Train 2) }\end{array}$ & $0.42 \pm 0.28$ & $0.34 \pm 0.28$ & $4.03 \pm 2.96$ & $3.87 \pm 3.18$ \\
\hline $\begin{array}{c}\text { BAC 2 } \\
\text { (Train 2) }\end{array}$ & $0.42 \pm 0.28$ & $0.35 \pm 0.28$ & $4.03 \pm 2.96$ & $3.63 \pm 3.71$ \\
\hline
\end{tabular}

The high average influent values for SUVA in Table 4.3 indicate a source of NOM which is aromatic in nature. Although both trains showed removals of UVA and SUVA, it can be seen from Table 4.3 that large standard deviations were encountered for the effluent SUVA values. These large standard deviations are a result of increasing SUVA removals upon increasing the ozone dosage from $1.55 \mathrm{mg} \mathrm{O} / \mathrm{mg}$ DOC to $3 \mathrm{mg} \mathrm{O} / \mathrm{mg}$ DOC on day 68 . Indeed, $\%$ SUVA removals increased from $5 \%$ to $22 \%$ for the SSF, $8.6 \%$ to $38 \%$ for BAC 1 and $10.5 \%$ to $40 \%$ for BAC 2 with the increase in ozone dosage.

It has been reported previously (Sohn et al., 2007) that a majority of the NOM removed by biofilters is aliphatic in nature which is readily biodegradable. Ozonation is responsible for breaking down the aromatic fractions into more readily biodegradable aliphatic fractions (Camel and Bermond, 1998) which would lead to a reduction in SUVA i.e. increase in SUVA removal. Here, an improvement in SUVA removal was observed upon increasing the ozone dosage; indicating that a dose of $1.55 \mathrm{mg} \mathrm{O} / \mathrm{mg}$ DOC was inadequate for the NOM in this water source. 
However, as a result of the ozone residual $(1.8 \mathrm{mg} \mathrm{O} / / \mathrm{L}$ in SSF and $2.17 \mathrm{mg} \mathrm{O} / \mathrm{L}$ in BAC filter) observed in Train 1 and 2 due to this high dosage, SUVA removals reduced to $0.4 \%$, $4.5 \%$ and $8.6 \%$ for SSF, BAC 1 and BAC 2 respectively (data not shown). Correlating these results with the previous ATP data, it is believed that the ozone residual destroyed the active portion of the biofilm and hence a reduction in SUVA removals was observed.

\subsection{Relationship between ATP concentrations and DOC removal}

ATP is the primary energy carrier in living cells (Caprita et al., 2006). It is feasible to assume that a majority of the active cells attached to filter media would be responsible for organics removal in biofiltration. Figure 4.3, Figure 4.4 and Figure 4.5 indicate the ATP biomass profile and \%DOC removals for SSF, BAC 1 and $\mathrm{BAC} 2$ respectively.

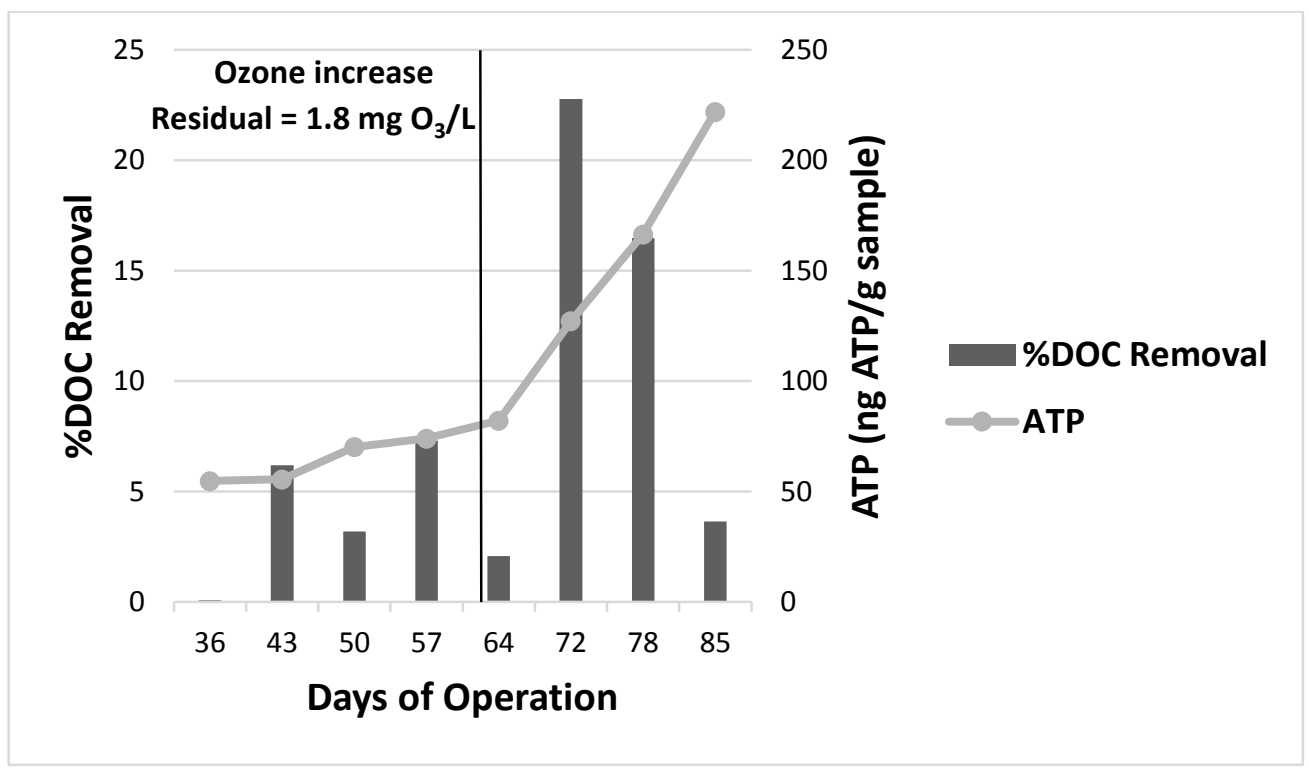

Figure 4.3: Impact of biomass concentration on \%DOC removal for SSF (Train 1) 


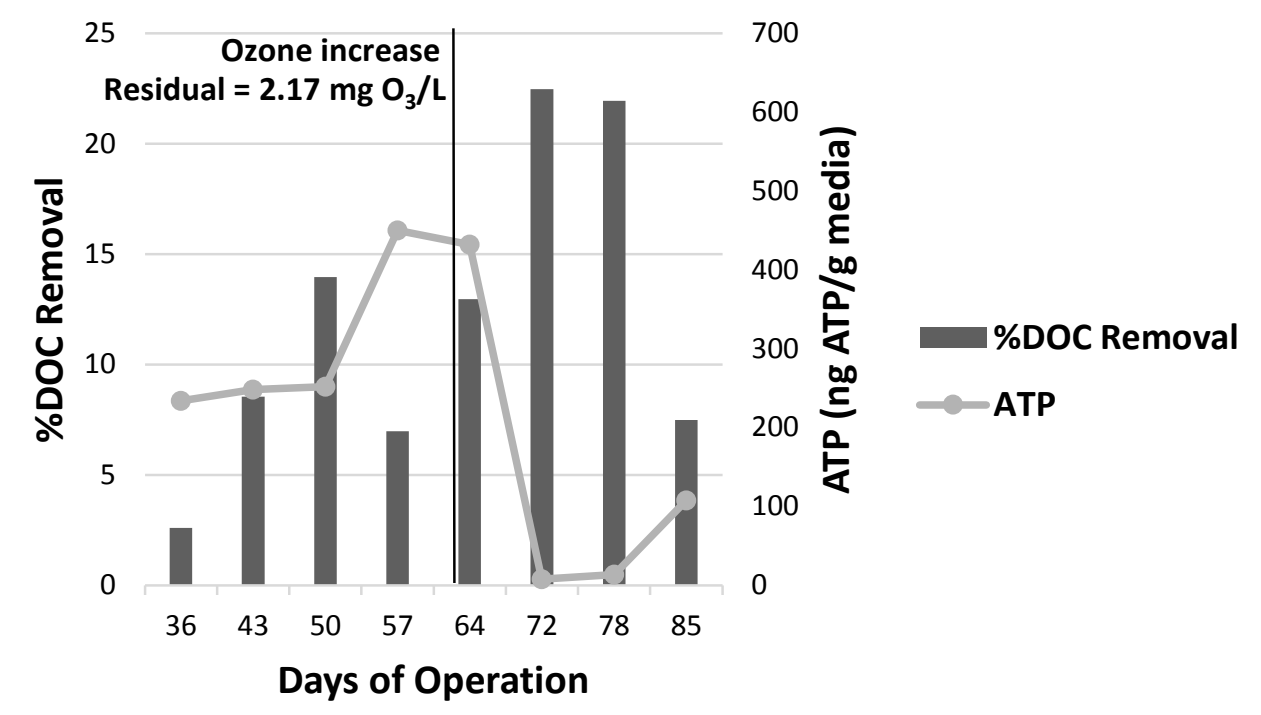

Figure 4.4: Relationship between ATP concentration and \%DOC removal for BAC 1 (Train 2)

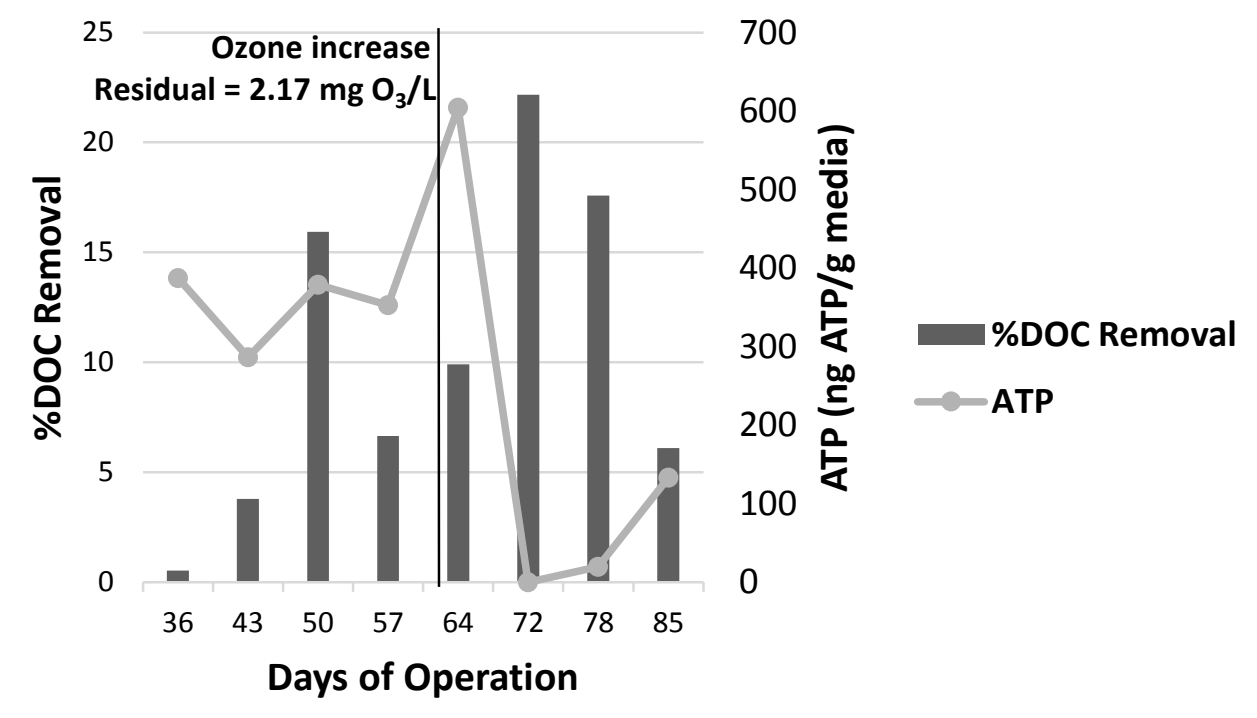

Figure 4.5: Relationship between ATP concentration and \%DOC removal for BAC 2 (Train 2)

Figure 4.3 shows an increase in ATP concentration for the SSF following the increase in ozone dosage. However, this increase in ATP concentration is accompanied by a reduction in $\% \mathrm{DOC}$ removal. 
Conversely, a different trend for the ATP values is observed for the two BAC filters. The decrease in \%DOC removal, although not immediate, can clearly be seen from Figure 4.4 and Figure 4.5 for these filters. A possible explanation for this could be the stratification of active biofilm throughout the depth of the filter. Here, only top of the filter ATP concentrations were being measured. However, it has been shown previously that biomass growth is observed throughout the depth of the filter (Boon et al., 2011; Velten et al., 2011).

It is believed that while the ozone residual may have destroyed the active biofilm in the top layer, the biofilm throughout the depth of the BAC filters was active in removing DOC. Further, DOC removals saw a sharp decrease around day 85 for the BAC filters, similar to what was observed for the SSF (despite increasing ATP concentrations). This reduction can thus be attributed to a reduction in water temperature which is known to play a significant role in the removal of organics (Hozalski et al., 1999; Persson et al., 2006)

\subsection{Preliminary Phase Conclusions}

A fair understanding of the impact of nutrient limited conditions and their impact on biofiltration performance was garnered over this preliminary study phase. DOC removals showed fluctuations over the course of the study which could be attributed to the nutrient limited nature of the raw water.

Low average \%DOC removals were observed for the SSF, BAC 1 and BAC $2(7.85 \%$, $10.29 \%$ and $8.38 \%$ respectively). Statistical analysis showed no significant difference between the two trains. It is believed that nutrient supplementation (nitrogen and phosphorous) to obtain a more balanced $\mathrm{C}: \mathrm{N}: \mathrm{P}$ ratio would be beneficial for improving system performance. 
No clear correlation could be drawn between the biomass concentrations and DOC removals as results from the SSF and the two BAC filters were conflicting. DOC removals reduced for the SSF despite increasing ATP concentrations whereas a reduction in ATP concentrations for the two BAC filters was accompanied by a gradual reduction in DOC removal. This was attributed to a reduction in water temperature. It was concluded that a better understanding of the biomass-DOC relationship could be garnered by monitoring biomass growth throughout the depth of the biofilter. This would be put into practice for the lab scale set of experiments.

As well, it was thought that perhaps the water only backwash procedure was insufficient for cleaning the BAC filters. Further, residual chlorine in the tap water used for backwashing may have been detrimental to biofilter performance. It was decided that an air scour assisted collapse-pulsing backwash would perhaps be more beneficial at the lab scale. 


\title{
5 Investigation into Nutrient Supplementation to Improve DOC Removal in Drinking Water Biofilters
}

Chapter 5 will be submitted as a journal article. As such, this chapter has been presented in the format of a journal article with planned submission to the journal Water Science and Technology (IWA Publishing). This paper will be published by co-authors Sahil Dhawan (student) and Dr. Onita Basu (supervisor). Sahil Dhawan was solely responsible for data collection and primarily responsible for the analysis and writing of this chapter.

\begin{abstract}
Analysis of the impacts of nitrogen, phosphorous and potassium supplementation on biofilter performance were studied on a lab scale. The columns were conditioned with nutrient limited synthetic raw water (SRW) for a four month period. The SRW consisted of glyoxal, acetic acid and formic acid as the carbon sources in order to make up average DOC concentrations of $11.57 \pm 2.32 \mathrm{mg} / \mathrm{L}$. As well, nitrogen and phosphorous were dosed to make up a $\mathrm{C}: \mathrm{N}: \mathrm{P}$ ratio of $546: 24: 1$ on a $\mathrm{w} / \mathrm{w}$ basis under nutrient limited conditions while nitrogen and phosphorous were added in ratios of 25:5:1 and 100:10:1 (w/w) under nutrient supplemented conditions. The nutrient limited column was compared under two different backwash scenarios one with water only and one with air scour and water. With the water only backwash, average \%DOC removal was $15.2 \%$ while with air scour and water, \%DOC removals averaged $22.9 \%$. Nutrient supplementation improved DOC removals to $32.2 \%$ for the $25: 5: 1$ column and $27.5 \%$ for the $100: 10: 1$ column. Potassium was also supplemented to the 25:5:1 column but with no discernible effect on DOC removal. However, potassium addition may have been responsible for a major sloughing
\end{abstract}


event for that column. Phospholipid values and ATP values were monitored during the study, with developed column conditions values in the range of $7-474 \mathrm{nmol} \mathrm{P} / \mathrm{g}$ media and $0.6 \times 10^{5}-32.74 \times 10^{5} \mathrm{pg}$ ATP/g sample respectively for top of the filter biomass.

\section{Key Words:}

Biofiltration, nutrient supplementation, phospholipid analysis, nitrogen, phosphorous, potassium

\subsection{Introduction}

Natural organic matter (NOM) is a ubiquitous component of surface waters. If left unremoved through the water treatment process, this organic matter has the potential to cause biological regrowth in water distribution systems. It can also lead to a higher chlorine demand and the formation of disinfection byproducts. Biofiltration is a sustainable technology that has the ability to remove NOM through biodegradation mechanisms of bacteria attached to filter media. For processes employing disinfection downstream of filtration, optimizing the filtration process could prove beneficial in terms of reducing the chemicals required and could decrease the formation of disinfection by products.

Currently, a wide range of physical parameters such as backwashing strategy, hydraulic loading rate and empty bed contact time (EBCT) are employed when designing filters for drinking water treatment. Further, many utilities choose to use chlorinated or chloraminated backwash water in an attempt to increase filter run times and maximize production. These backwash procedures however, can be detrimental to biological activity within a potential biofilter. While physical parameters such as EBCT play an important role in the functioning of a filtration process, current filtration design practices do not 
account for optimizing biological growth on the media. However, biological degradation of dissolved organic contaminants is an added potential advantage of biofiltration. Furthermore, past research has shown that biodegradation has led to prolonged bed life of GAC biofilters (Sakoda et al., 1996; Takeuchi et al., 1997; Ghosh et al., 1999).

It has been noted that carbon:nitrogen:phosphorous $(\mathrm{C}: \mathrm{N}: \mathrm{P})$ ratios less than $100: 10: 1$ on a mol basis are detrimental to obtaining an optimized biofiltration process (LeChevallier et al., 1991). The 100:10:1 molar C:N:P ratio is equivalent to a $\mathrm{C}: \mathrm{N}: \mathrm{P}$ ratio of $39: 4.5: 1$ on a w/w basis. Coagulants such as alum (used commonly in water treatment) have proven effective in precipitating phosphorous (Tchobanoglous and Burton, 1991). Thus, phosphorous concentrations to downstream filter influents are usually in the range of 2 $11 \mu \mathrm{g}$ P/L (Nishijima et al., 1997). It has been demonstrated that phosphorous concentrations below $5 \mu \mathrm{g} / \mathrm{L}$ impede the typical transport mechanism of phosphorous through membranes within bacterial cells (Rosenberg, 1987). Thus, in order to promote cell development and by extension biofilm growth, it would perhaps be prudent to have phosphorous concentrations greater than $5 \mu \mathrm{g} / \mathrm{L}$ in biofilter influents. In a previous study conducted by Sang et al. (2003), biofilters dosed with $25 \mu \mathrm{g} \mathrm{PO}{ }^{3-} \mathrm{P} / \mathrm{L}$ were compared with columns not receiving phosphorous. They found TOC removals on average to be $22 \%$ $26.6 \%$ for the phosphorous supplemented column versus $17.1 \%-21.3 \%$ for the phosphorous limited column.

Given the complex nature of bacterial biomass attached to filter media, it is indeed possible that several factors play a key role in organics removal. In addition to nitrogen and phosphorous, potassium may also play a role in biofilter development. For instance, in wastewater systems, Brdjanovic et al. (1996) investigated the effects of potassium on 
biological phosphate removal in a sequenced batch reactor operating in anaerobic-aerobicsettling mode. They observed $0.33 \mathrm{~mol} \mathrm{~K} / \mathrm{mol} \mathrm{P}$ within the biomass following the aerobic phase. Further, potassium limited conditions $\left(7.15 \times 10^{-4} \mathrm{~mol} \mathrm{~K} / \mathrm{mol} \mathrm{P}\right.$ in the influent) showed no biological phosphorous uptake when compared to a ratio of $1 \mathrm{~mol} \mathrm{~K} / \mathrm{mol} \mathrm{P}$ in the influent, where complete biological phosphate removal was observed. Thus, it is feasible that in drinking water biofilms, potassium may have a potential role to play in improving phosphorous uptake and hence organic carbon removal. However, the effects of potassium supplementation on drinking water biofilter systems has not been studied in detail.

The research objectives of this work were to investigate the impact of nitrogen and phosphorous enhancement on biofiltration performance from an organics removal perspective. As well, analysis of the impacts of potassium is also discussed. Finally, a comparison between water only backwash and backwash with water and air scour is discussed.

\subsection{Materials and Methods}

\subsubsection{Biofilter Setup}

Each column was made of plexiglass and was $1250 \mathrm{~mm}$ tall with a diameter of $50 \mathrm{~mm} .520$ $\mathrm{mm}$ of GAC was placed atop $180 \mathrm{~mm}$ of sand with a synthetic underdrain material below it. The flow rate through each column was kept at $100 \mathrm{ml} / \mathrm{min}$ to allow for an empty bed contact time of 15 minutes. 


\subsubsection{Experimental Methodology}

A preliminary study phase employed the use of a pilot scale multi-stage filtration (MSF) system that was set up at the Britannia Water Treatment Plant in Ottawa, ON, Canada. This preliminary phase provided baseline information (data not shown) which was carried forward at the lab scale.

Lab scale experiments were conducted over the course of three phases. Phase 1 consisted of a nutrient limited conditioning phase $(\mathrm{C}: \mathrm{N}: \mathrm{P}=546: 24: 1 \mathrm{w} / \mathrm{w})$. The nutrient limited conditions were reflective of the intake water condition to the pilot scale MSF at BWTP. Phase 2 implemented nitrogen, phosphorous enhancement for two of the three columns to achieve C:N:P ratios of 25:5:1 and 100:10:1 on a w/w basis. For Phase 3, potassium was supplemented for the column with a C:N:P of 25:5:1. Table 5.1 provides details about the various phases of research.

Table 5.1: Experimental Phase Description

\begin{tabular}{|c|c|c|c|c|}
\hline Phase & Comments & $\begin{array}{c}\text { C:N:P Ratio } \\
(\mathbf{w} / \mathbf{w})\end{array}$ & $\begin{array}{c}\text { Column } \\
\text { Abbreviation* }\end{array}$ & Duration \\
\hline 1 & $\begin{array}{l}\text { Filter conditioning phase } \\
\text { Water only backwash for all columns }\end{array}$ & $\begin{array}{c}546: 24: 1 \\
\text { (All Columns) }\end{array}$ & $\begin{array}{l}1-\mathrm{NL} \\
2-\mathrm{NL} \\
3-\mathrm{NL}\end{array}$ & $\begin{array}{c}\text { May } 2014 \\
\text { to } \\
\text { August } 2014\end{array}$ \\
\hline \multirow{3}{*}{2} & \multirow{3}{*}{$\begin{array}{l}\text { Nitrogen, phosphorous enhancement for } \\
\text { columns } 2 \text { and } 3 \\
\text { Collapse pulsing backwash procedure } \\
\text { employed for all columns }\end{array}$} & $25: 5: 1$ & $1-\mathrm{NS} \mathrm{A}$ & \multirow{3}{*}{$\begin{array}{c}\text { August } 2014 \\
\text { to } \\
\text { December } \\
2014\end{array}$} \\
\hline & & 100:10:1 & 2 - NS B & \\
\hline & & $546: 24: 1$ & $3-N L$ & \\
\hline \multirow[b]{3}{*}{3} & \multirow{3}{*}{$\begin{array}{l}\text { Nitrogen, phosphorous enhancement for } \\
\text { columns } 2 \text { and } 3 \\
\text { Potassium supplementation for } 1 \text { - NS A } \\
\text { Collapse pulsing backwash procedure } \\
\text { employed for all columns }\end{array}$} & $25: 5: 1$ & $1-\mathrm{NS} \mathrm{A}+\mathrm{K}$ & \multirow{3}{*}{$\begin{array}{c}\text { January } 2015 \\
\text { to } \\
\text { April } 2015\end{array}$} \\
\hline & & 100:10:1 & 2 - NS B & \\
\hline & & $546: 24: 1$ & $3-\mathrm{NL}$ & \\
\hline
\end{tabular}

*1, 2, 3 - Column numbers, NS A = Nutrient Supplement Condition A, NS B = Nutrient

Supplement Condition B, NL = Nutrient Limited Condition, $\mathrm{K}=$ Potassium 
All filters were backwashed once a week. In Phase 1, a water only backwash procedure with a backwash velocity of $30 \mathrm{~m} / \mathrm{hr}$ to achieve $30 \%$ GAC bed expansion was employed. In Phase 2 and 3, an air scour assisted collapse pulsing procedure was employed. This consisted of 6 minutes combined air/water wash (backwash velocity $=12 \mathrm{~m} / \mathrm{hr}$ and air velocity $=72 \mathrm{~m} / \mathrm{hr}$ ) followed by a high rate water only wash (backwash velocity $=30 \mathrm{~m} / \mathrm{hr}$ with $30 \%$ GAC bed expansion) for 2 minutes and finally a low rate water only wash (backwash velocity $=10 \mathrm{~m} / \mathrm{hr}$ ) for 2 minutes.

\subsubsection{Dosing Solutions}

Dosing solutions were mixed with dechlorinated tap water using an in-line static mixer. This would serve as the influent to the columns. Dosing solutions were prepared using distilled water. Stock solutions were prepared with the requisite chemicals in $1 \mathrm{~L}$ volumetric flasks which were thoroughly rinsed with phosphate free soap and deionized water. Stock solutions were mixed placed in their respective tanks using a stand mixer. The dosing solutions were placed in two separate 50 L Nalgene heavy cylindrical containers. One tank contained the carbon dosing solution, prepared with glyoxal (Fisher Scientific), acetic acid (Fisher Scientific) and formic acid (Fisher Scientific). The other contained nitrogen, phosphorous and micronutrients dosing solution, prepared using sodium nitrate (Sigma-Aldrich) and potassium dihydrogen phosphate (Fisher Scientific). For nitrogen, phosphorous supplementation, sodium nitrate and potassium dihydrogen phosphate were used. This provided C:N:P ratios of 25:5:1 and 100:10:1 on a w/w basis. Potassium was supplemented in the form of potassium sulphate (Sigma-Aldrich). 


\subsection{Analysis of Parameters}

\subsubsection{Total Organic Carbon (TOC) and Dissolved Organic Carbon (DOC)}

TOC and DOC were measured in accordance with the Persulfate Ultraviolet Oxidation Method in Standard Methods 5310C (APHA, 2012). DOC analysis was performed using a SHIMADZU TOC-VCPH/ CPN total organic carbon analyzer. Prior to DOC analysis, samples were filtered through a $0.45 \mu \mathrm{m}$ filter (Millipore).

\subsubsection{Ultraviolet Absorbance (UVA) at $254 \mathrm{~nm}$ and SUVA}

Samples were filtered through a $0.45 \mu \mathrm{m}$ filter (Millipore). UVA at $254 \mathrm{~nm}$ was measured in accordance with Standard Methods 5910B (APHA, 2012). Samples were placed in a quartz cuvette ( $1 \mathrm{~cm}$ in length) and UVA value at $254 \mathrm{~nm}$ was then recorded using a UV visible Spectrophotmeter (Spectronic Unicam).

Specific ultraviolet absorbance (SUVA) was calculated as the UV absorbance values at $254 \mathrm{~nm}$ normalized by the DOC concentration.

$$
\operatorname{SUVA}\left(\frac{L}{m g \cdot m}\right)=\frac{U V A_{254}\left(\mathrm{~cm}^{-1}\right)}{\operatorname{DOC}\left(\frac{m g}{L}\right)} \times 100
$$

\subsubsection{Total Nitrogen}

Total nitrogen analysis was carried out using a SHIMADZU TNM-1 total nitrogen analyzer. All samples were filtered using a $0.45 \mu \mathrm{m}$ filter (Millipore) prior to analysis. 


\subsubsection{Phosphorous}

The PhosVer 3 method (\#8190) was used to analyze phosphorous with a HACH DR2800 spectrophotometer. Phosphorous concentrations ranged from 8 - $13 \mu \mathrm{g} / \mathrm{L}$ for column 3 NL, $80-150 \mu \mathrm{g} / \mathrm{L}$ for column 2 - NS B and $240-300 \mu \mathrm{g} / 1$ for column 1 - NS A respectively.

\subsubsection{Potassium}

Potassium was analyzed using the Tetraphenylborate method (\#8049) and a HACH DR2800 spectrophotometer. This method can detect potassium concentrations in the range of $0.1-7 \mathrm{mg} \mathrm{K} / \mathrm{L}$.

\subsubsection{Biomass Quantification}

Phospholipid analysis was carried out in accordance with the procedure described by Wang et al. (1995). $1 \mathrm{~g}$ of media was drawn from two sampling ports located at $5 \mathrm{~cm}$ and $18 \mathrm{~cm}$ from the top of the filter media. These measurements represent biomass from the top and middle of each column.

ATP analysis was carried out using the Deposit Surface Analysis Test (LuminUltra Technologies Ltd., NB) and Luminometer (PhotonMaster) according to manufacturer protocols. $1 \mathrm{~g}$ of media was drawn from two sampling ports located at $5 \mathrm{~cm}$ and $18 \mathrm{~cm}$ from the top of the filter media.

\subsubsection{Temperature, $\mathrm{pH}$}

Temperature and $\mathrm{pH}$ were monitored using a $\mathrm{pH}$ probe (Thermo Scientific ORION 087003). A three-point $\mathrm{pH}$ calibration was carried out at $\mathrm{pH} 4,7$ and 10. 


\subsection{Lab Scale Results}

\subsubsection{Phase 1 - Biofilter Conditioning}

Columns were run under nutrient limited conditions for a period of 4 months, with regular measurements of DOC and UVA started at the 50 day mark. Given the identical nutrient limited conditions in each of the columns, steady state DOC removals were achieved after approximately 50 days of operation as seen in Figure 5.1. Average DOC removals ranged from $13.5 \%$ (column 2 - NL) to $15.3 \%$ (column 3 - NL). Table 5.2 shows the average \%DOC removals at the pilot plant at the BWTP and in the lab biofilter columns.

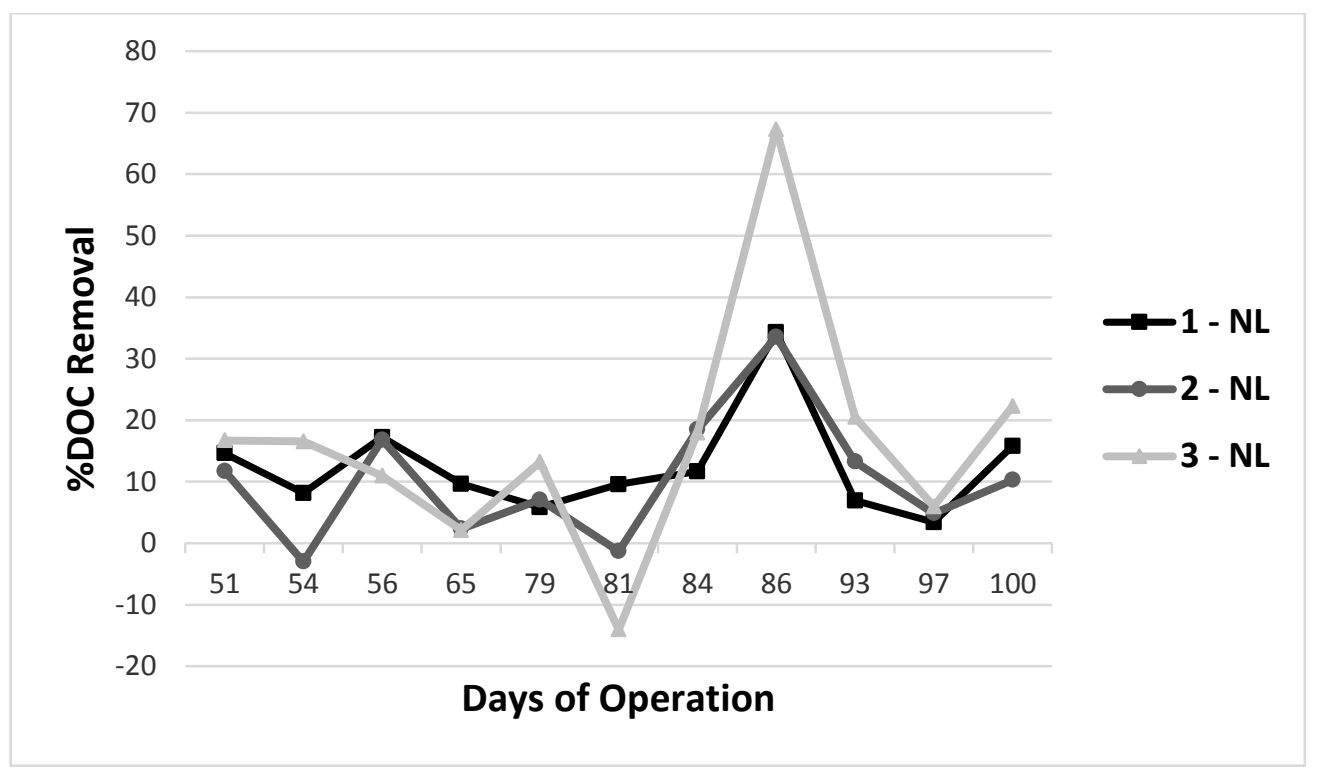

Figure 5.1: \%DOC removal over Phase 1 
Table 5.2: Comparison of average \%DOC removals at the end of pilot, lab scale studies

\begin{tabular}{|c|c|c|c|c|}
\hline Site & $\begin{array}{c}\text { Brittania Pilot } \\
\text { (Preliminary Phase) }\end{array}$ & \multicolumn{3}{|c|}{$\begin{array}{l}\text { Lab Scale Study } \\
\text { (Phase 1) }\end{array}$} \\
\hline Column & BAC Filter & $1-N L$ & $2-N L$ & 3 - NL \\
\hline $\begin{array}{c}\text { Average \%DOC } \\
\text { Removal }\end{array}$ & 9.33 & 13.67 & 13.52 & 15.33 \\
\hline
\end{tabular}

It is evident here that slightly higher removals were achieved in the lab as compared to the pilot setup. However, this was to be expected, given the biodegradable nature of the carbon sources being used in the synthetic raw water source. A t-test of the three columns showed no statistical difference $(\mathrm{p}>0.05)$; indicating the columns were performing similarly.

Table 5.3 indicates the average influent and effluent values of $\mathrm{UVA}_{254}$ and $\mathrm{SUVA}_{254}$ for each of the 3 columns.

Table 5.3: Average, maximum and minimum values for UVA254 and SUVA254 for Phase 1

\begin{tabular}{|c|c|c|c|c|}
\hline & \multicolumn{2}{|c|}{$\mathrm{UVA}_{254}\left(\mathrm{~cm}^{-1}\right)$} & \multicolumn{2}{|c|}{ SUVA254 $_{2}\left(\mathrm{~L} \cdot \mathrm{mg}^{-1} \mathrm{~m}^{-1}\right)$} \\
\hline Condition & Average \pm SD & Range & Average \pm SD & Range \\
\hline $1-\mathrm{NL}$ & $0.07 \pm 0.02$ & $0.02-0.11$ & $0.73 \pm 0.17$ & $0.2-4.61$ \\
\hline $2-\mathrm{NL}$ & $0.09 \pm 0.08$ & $0.01-0.45$ & $0.75 \pm 0.7$ & $0.13-3.93$ \\
\hline $3-\mathrm{NL}$ & $0.08 \pm 0.03$ & $0.01-0.16$ & $0.86 \pm 0.19$ & $0.13-6.76$ \\
\hline
\end{tabular}

High SUVA values indicate a high aromatic NOM fraction (Weishaar et al., 2003). The low average values for SUVA in Table 5.3 indicate a source of NOM which is non-aromatic in nature which is to be expected. 


\subsubsection{Phase 2 - Impact of Nutrient Supplementation}

Once the columns had been operated for a 4 month period, steady state removal of DOC was observed and Phase 2 was initiated. At this time, supplementary nitrogen and phosphorous were added to two of the three columns to achieve a $\mathrm{C}: \mathrm{N}: \mathrm{P}$ ratio of 25:5:1 (Tchobanoglous et al., 2003) and 100:10:1 (Anderson et al., 2008) respectively on a w/w basis.

Figure 5.2 shows the \%DOC removals for the three nutrient conditions over Phase 2. On day 161, a pink coloured biomass growth was observed in the influent tubings as well as the static mixer. This biomass resulted in a clogging of the top of biofilter columns and coincided with an associated reduction in DOC through the system. On day 171, the columns were taken offline and an extended cleaning procedure was carried out on the system. The static mixer and influent tubings were soaked in a citric acid solution $(2.5 \mathrm{~g}$ in 3 L) for 4 hours. Columns were then backwashed on day 173 and following this, DOC removals increased. Average \%DOC removals prior to the clean were approximately $35 \%$, $32 \%$ and $21 \%$ for $1-$ NS A, $2-$ NS B and $3-$ NL respectively. Following the system clean, average $\%$ DOC removals were approximately $31 \%, 24.6 \%$ and $24.5 \%$ respectively for 1 NS A, 2 - NS B and 3 - NL respectively. Thus, the system clean resulted in an improvement in \%DOC removal for 3 - NL (approximately 8\%) indicating that the pink biomass was more detrimental to the nutrient limited column.

Prior to day 178 , water temperature entering the columns remained fairly constant in the range of $18-20^{\circ} \mathrm{C}$. However, beyond this point, temperature fluctuations were observed. Beyond day 178, the tap water temperature saw a gradual decrease from $20^{\circ} \mathrm{C}$ to $13{ }^{\circ} \mathrm{C}$. Upon further inspection, it is observed that the column receiving the higher ratio of 25:5:1 
(1 - NS A) appeared to be more resistant to these temperature fluctuations as opposed to the column receiving a lower C:N:P ratio of 100:10:1 (2 - NS B). Upon further analysis of the nutrient limited ( 3 - NL) column, significant variations are still observed over the course of the study period. This would supply further evidence to the theory that nutrient limited conditions are not ideal in a water treatment scenario for organics removal and would be in agreement with previous research (Sang et al., 2003; Lauderdale et al., 2012).

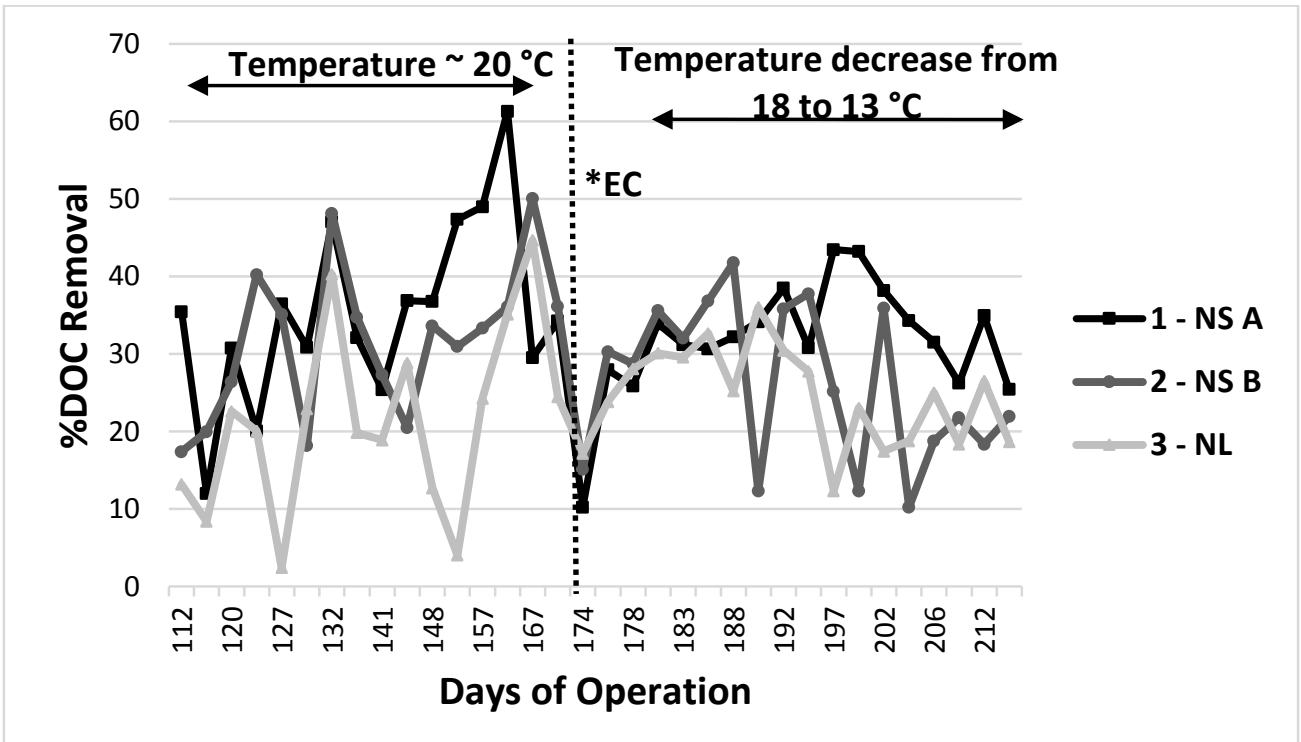

Figure 5.2: \%DOC removals over Phase 2 (*EC - Extended system clean - rinsed static mixer, tubing in citric acid solution to remove biomass growth)

The removals for each columns before and after cleaning were not found to be statistically different $(p>0.05)$. Therefore, a comparison of column performance over the entire Phase 2 was completed. A paired t-test found that while DOC removals were different for columns $1-\mathrm{NS}$ A and $3-\mathrm{NL}(\mathrm{p}<0.05)$, the same cannot be said when comparing 1 - NS A with 2 - NS B and 2 - NS B with 3 - NL respectively. Although the p values for both these comparisons indicate statistically significant differences, the same cannot be inferred 
from analysis of the $t$ Stat and t Critical two tail values. Thus, in both these cases, results should be viewed with some caution. The effect of the extended clean procedure on DOC removals can be observed in Table 5.4 below.

Table 5.4: Effect of EC on \%DOC removal

\begin{tabular}{|c|c|c|c|}
\hline Column & $\begin{array}{c}\text { Overall \%DOC } \\
\text { Removal } \\
(\mathbf{n}=\mathbf{3 5})\end{array}$ & $\begin{array}{c}\text { \%DOC Removal } \\
\text { (before EC) } \\
(\mathbf{n}=\mathbf{1 6})\end{array}$ & $\begin{array}{c}\text { \%DOC Removal } \\
\text { (after EC) } \\
(\mathbf{n}=\mathbf{1 9})\end{array}$ \\
\hline 1 - NS A & $32.8 \pm 10.4$ & $35.3 \pm 11.9$ & $30.7 \pm 8.7$ \\
\hline 2 - NS B & $27.9 \pm 11.3$ & $31.8 \pm 9.8$ & $24.6 \pm 11.7$ \\
\hline 3 - NL & $23.1 \pm 9.6$ & $21.4 \pm 12.0$ & $24.5 \pm 7.2$ \\
\hline
\end{tabular}

Between Phase 1 and 2, the backwash procedure was altered to include air scour. This resulted in a measurable improvement in DOC removal in the nutrient limited column (3 NL) from $15.3 \%$ to approximately $23 \%$ (statistically significant with $\mathrm{p}<0.05$ ). This improvement in results associated with backwashing highlights the importance of implementing optimized backwash techniques for biofiltration to ensure maximum DOC removal. This is in contrast to results reported at similar temperature ranges by Emelko et al. (2006); however it should be noted that the study was conducted under non-nutrient limited conditions. This may indicate a greater sensitivity for DOC removal under conditions of stress i.e. nutrient limited conditions. Furthermore, there was no statistical change in DOC removal in the nutrient limited column ( $3-\mathrm{NL})$ between Phase 2 and 3 when conditions were maintained and backwashing was with air scour in these circumstances $(\mathrm{p}>0.05)$. 
Nutrient supplementation was found to positively impact DOC removals. On average, DOC removal for 1 - NS A was found to be $12 \%$ higher than the nutrient limited control column. This increase was less apparent in 2 - NS B where a $4 \%$ increase was observed compared to the control. However, a statistical analysis of average \%DOC removals showed statistically significant differences ( $95 \%$ confidence interval).

Table 5.5 shows the variation in influent and effluent $\mathrm{UVA}_{254}$ and $\mathrm{SUVA}_{254}$ over the course of Phase 2.

Table 5.5: Average influent, effluent UVA254 and SUVA254 values for Phase 2

\begin{tabular}{|c|c|c|c|c|}
\hline \multirow[b]{2}{*}{\begin{tabular}{|l|} 
Nutrient \\
Condition
\end{tabular}} & \multicolumn{2}{|c|}{$\operatorname{UVA}_{254}\left(\mathrm{~cm}^{-1}\right)$} & \multicolumn{2}{|c|}{ SUVA $_{254}\left(\mathbf{L} \cdot \mathrm{mg}^{-1} \mathrm{~m}^{-1}\right)$} \\
\hline & $\begin{array}{c}\text { Influent } \\
\text { Average } \pm \text { SD }\end{array}$ & $\begin{array}{c}\text { Effluent } \\
\text { Average } \pm \text { SD }\end{array}$ & $\begin{array}{c}\text { Influent } \\
\text { Average } \pm \text { SD }\end{array}$ & $\begin{array}{c}\text { Effluent } \\
\text { Average } \pm \text { SD }\end{array}$ \\
\hline 1 - NS A & $0.07 \pm 0.02$ & $0.06 \pm 0.01$ & $0.59 \pm 0.24$ & $0.76 \pm 0.16$ \\
\hline 2 - NS B & $0.07 \pm 0.01$ & $0.06 \pm 0.02$ & $0.61 \pm 0.2$ & $0.76 \pm 0.27$ \\
\hline $3-N L$ & $0.07 \pm 0.01$ & $0.06 \pm 0.01$ & $0.58 \pm 0.18$ & $0.64 \pm 0.19$ \\
\hline
\end{tabular}

As compared to DOC removals, larger fluctuations were observed in the system when it came to analyzing SUVA removals. Although a reduction in DOC and UVA values were observed for all columns, an analysis of the SUVA values shows a different trend. Throughout the course of Phase 2, effluent SUVA values were consistently higher than influent SUVA values for all columns. On average, effluent SUVA values were 29\%, 25\% and $10 \%$ higher than the influent for 1 - NS A, 2 - NS B and 3 - NL respectively.

SUVA is a parameter that provides an indication of the dissolved aromatic carbon content in aquatic systems (Weishaar et al., 2003). As demonstrated in Phase 1, low SUVA values are indicative of a primarily aliphatic NOM source. Basu and Huck (2004b) studied humic 
acid (representative of a large portion of the aromatic fraction of NOM) removal through biofilters. They reported several instances of higher SUVA values in the biofilter effluent despite DOC and UVA removals. They theorized that although the biodegradable component of DOC was removed by the filters, DOC contributing to UVA absorbance (aromatic fraction) was not removed to the same extent. Indeed it has been previously reported that removal of aromatic NOM takes place preferentially in coagulation/flocculation processes whereas biofilters preferentially remove aliphatic compounds (Sohn et al., 2007). Thus, given here that the NOM source is primarily aliphatic in nature, perhaps SUVA is not a worthy indicator of system performance.

Yapsakli and Cecen (2010) plotted \%DOC removal by biofilters against influent SUVA values. It was observed that as the influent SUVA values increased, \%DOC removal reduced. A similar trend was observed for all columns in this study. Maximum \%DOC removals were observed when SUVA values were in the range of $0.3-0.7 \mathrm{~L} \cdot \mathrm{mg}^{-1} \mathrm{~m}^{-1}$.

\subsubsection{Phospholipid Analysis}

Phospholipid analysis of biomass media was conducted by collecting GAC media samples from sampling ports located $5 \mathrm{~cm}(\mathrm{GAC} 1)$ and $18 \mathrm{~cm}$ (GAC 2) from the top of the GAC media. Results were reported as $\mathrm{nmol} \mathrm{P} / \mathrm{g}$ media. In an effort to draw conclusions regarding the impact of biomass concentration on organics removal, phospholipid profiles were plotted against \%DOC removals. Figure 5.3, Figure 5.3 and Figure 5.4 show \%DOC removal on the primary y-axis and the phospholipid profile from $5 \mathrm{~cm}$ below the top of the media and $18 \mathrm{~cm}$ below the top of the media on the secondary y-axis for 1 - NS A, 2 - NS B and 3 - NL respectively. 
Initial observation suggests that 1 - NS A had a higher concentration of phospholipid biomass attached to the filter media over the course of Phase 2. Phospholipid counts for each measurement were averaged (average of the top and middle values) for each sampling point and no statistical difference was observed $(\alpha=0.05)$ over the course of Phase 2 between the columns. It was observed that phospholipid counts at the top of the filter bed were higher than those in the middle of the bed. This would be consistent with previous results from literature (Wang et al., 1995; Moll et al., 1999; Liao et al., 2013).

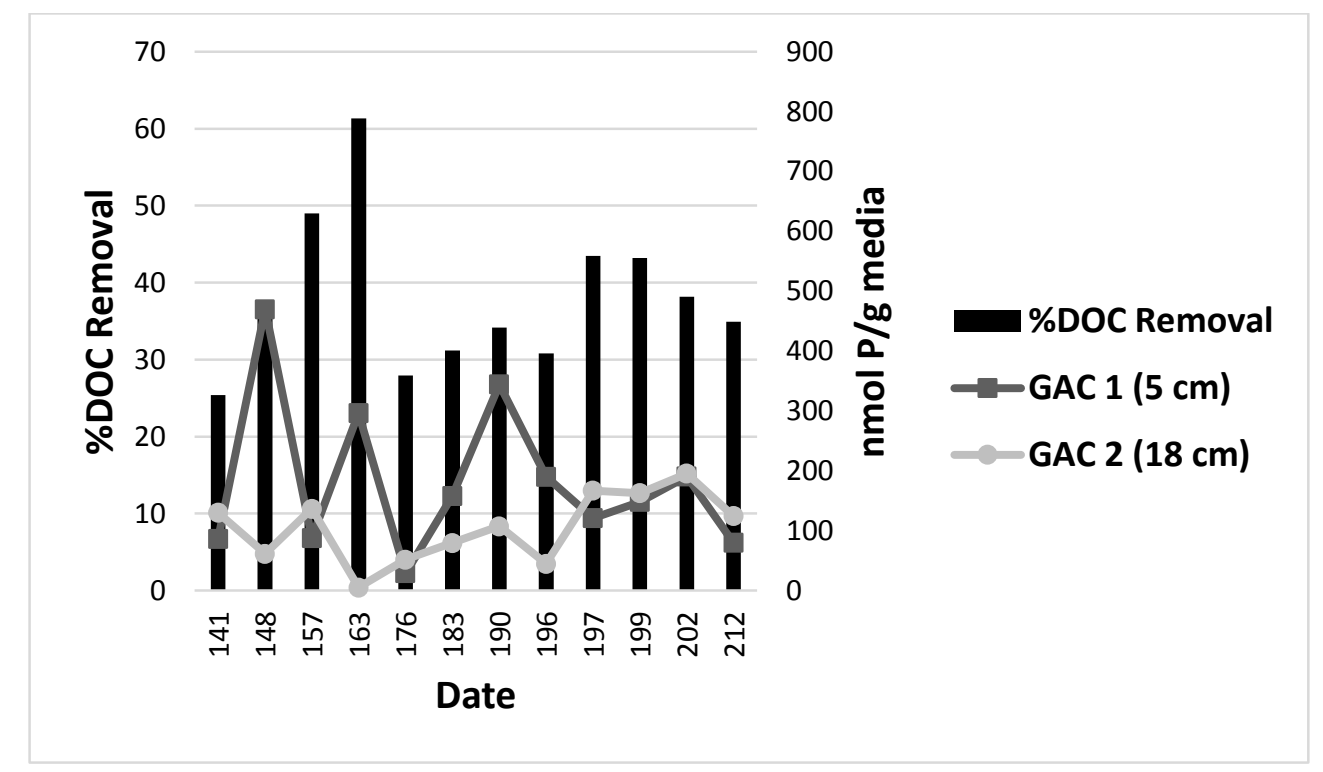

Figure 5.3: Impact of biomass concentration on \%DOC removal for 1 - NS A 


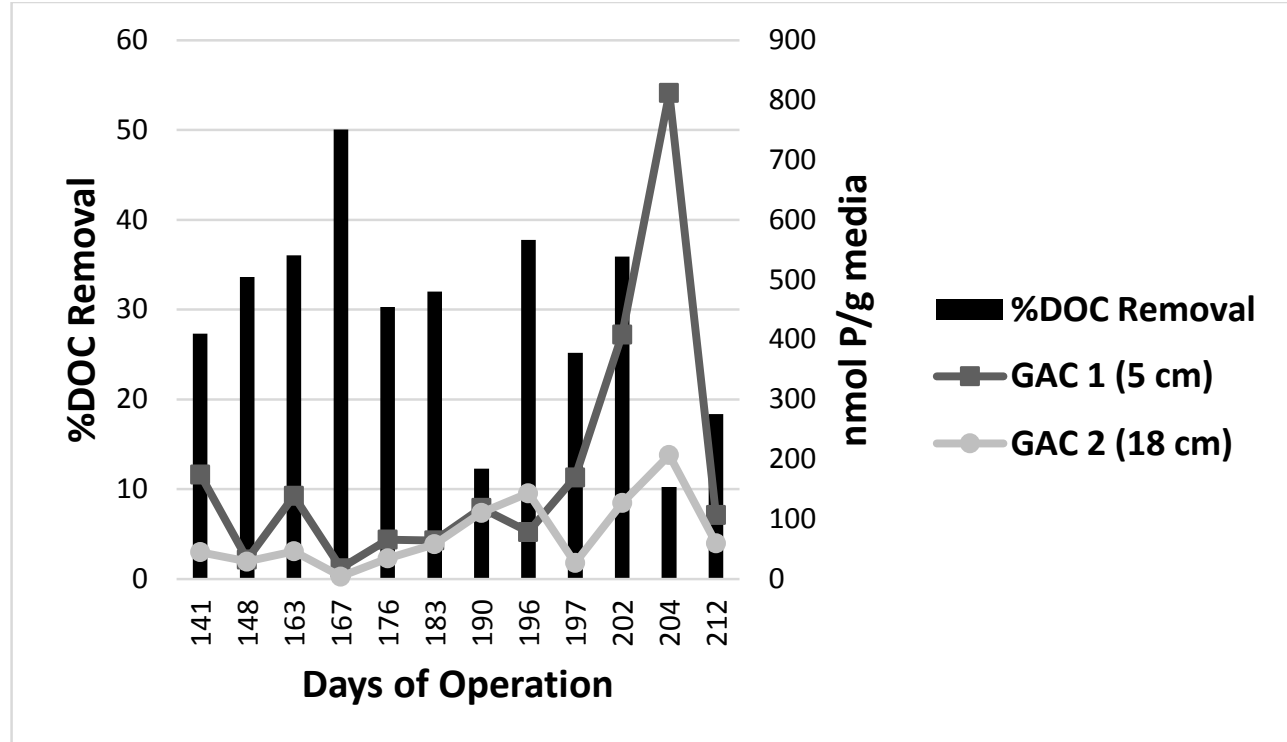

Figure 5.4: Impact of biomass concentration on \%DOC removal for 2 - NS B

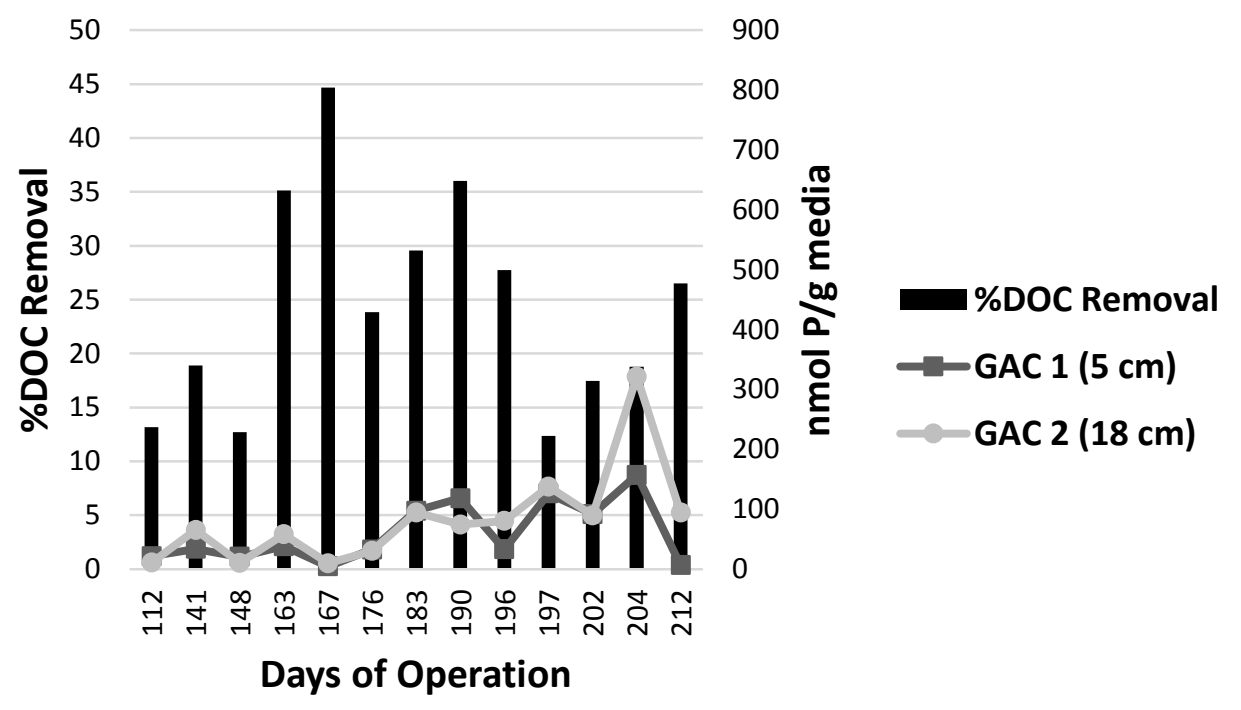

Figure 5.5: Impact of biomass concentration on \%DOC removal for 3 - NL

Results in literature regarding phospholipid analysis and DOC removals have been conflicting (Fonseca et al., 2001; Urfer and Huck, 2001; Emelko et al., 2006; Boon et al., 2011). Phospholipid analysis is a relatively easy measurement to take and does provide general data on bacterial activity. However, the lack of a better correlation with DOC data 
points to the fact that better genomic data is needed for biofilter optimization research. As noted, there was no clear correlation between biomass concentrations and DOC removal. As can be seen from Figure 5.3 and Figure 5.4, despite low phospholipid counts, \%DOC removals remain in the $30 \%$ range.

\subsubsection{Phase 3 - Impact of Potassium Addition on Biofilter Performance}

Potassium has been found to be an important parameter in the biological uptake of phosphorous in wastewater treatment systems (Brdjanovic et al., 1996). However, there is a lack of information on the effects of potassium addition on the performance of drinking water biofilters. The aim of this phase of the study was to develop an understanding of the impacts of potassium supplementation on carbon uptake in a drinking water treatment scenario. The other conditions for all columns remained the same from Phase 2. During Phase 3, the water temperature was approximately $11{ }^{\circ} \mathrm{C}$ throughout the course of the study.

Between Phase 2 and 3, the columns were shut down for 2 weeks and then conditioned for 3 weeks before regular sampling was initiated. DOC removals during Phase 3 were generally similar to DOC removals observed during Phase 2. However, several spikes in DOC removals were observed, with removals as high as $75 \%$ being achieved; although the reasons for high DOC removals are not understood at this point. As the overall DOC removals between Phase 2 and 3 were the same, it did not appear as though potassium supplementation improved biofilter performance with respect to DOC removal.

Average \%DOC removals for Phase 3 are shown in Figure 5.6. No statistical differences were observed between the two nutrient supplemented columns $1-\mathrm{NS} \mathrm{A}+\mathrm{K}$ and $2-\mathrm{NS}$ B $(\alpha=0.05)$. However, there continued to be statistically significant differences between 
the nutrient supplemented columns and the nutrient limited column i.e. $1-\mathrm{NS} \mathrm{A}+\mathrm{K}$ and $3-\mathrm{NL}(\mathrm{p}<0.05)$ and $2-\mathrm{NS} B$ and $3-\mathrm{NL}(\mathrm{p}<0.05)$.

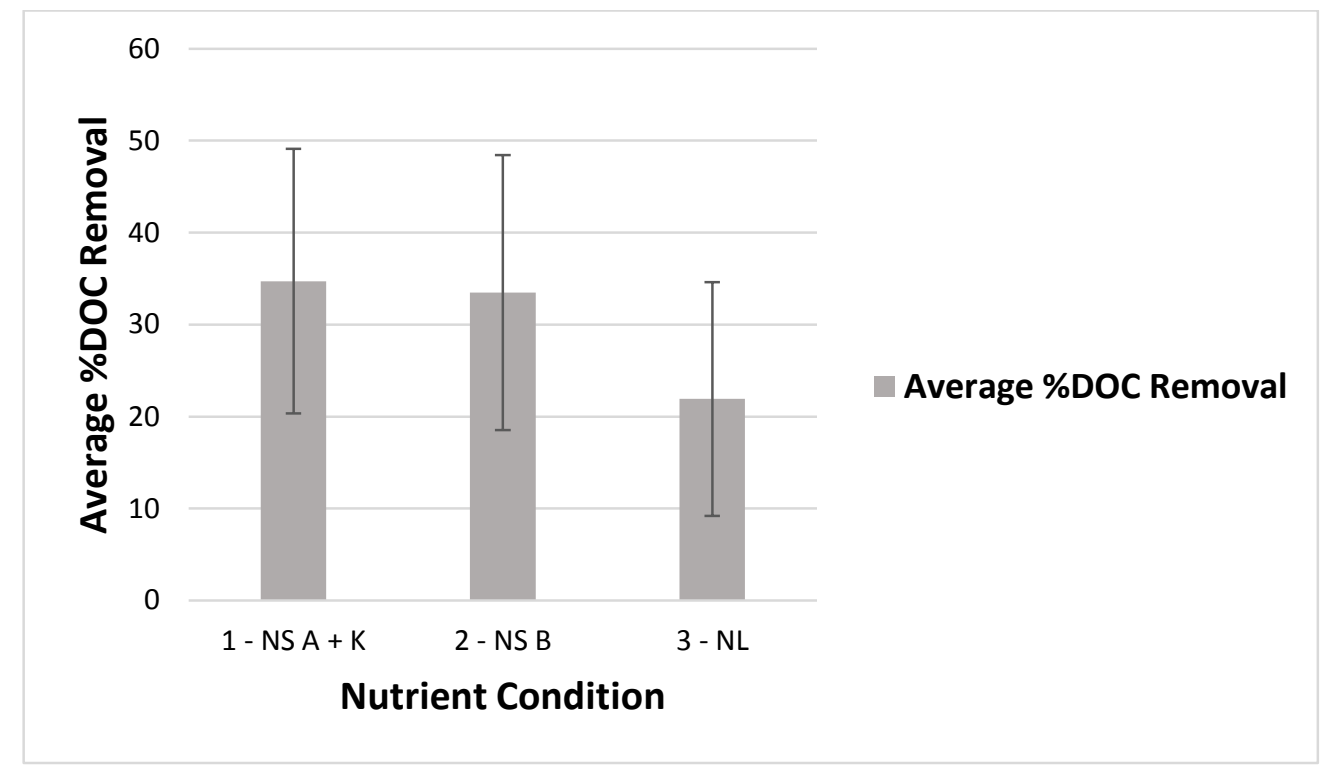

Figure 5.6: Average \%DOC removals for Phase 3

An impact of the reduction in water temperature $\left(20^{\circ} \mathrm{C}\right.$ from Phase 2 to $11^{\circ} \mathrm{C}$ in Phase 3$)$ was not observed on any of the columns as seen from Table 5.6 and Figure 5.7. While nutrient supplementation did result in an approximate $10-12 \%$ increase in DOC removal compared to the nutrient limited column, it was less than expected given the readily biodegradable nature of the carbon sources in the synthetic raw water source. For instance, Lauderdale et al. (2012) achieved approximately 75\% greater removals from nutrient enhanced biofilters as opposed to their nutrient limited control. Basu and Huck (2004a) have reported TOC removals as high as $50 \%$ for columns receiving a $\mathrm{C}: \mathrm{N}: \mathrm{P}$ of $15: 5: 1$ on a weight basis. 
Table 5.6: \%DOC removals over 3 phases

\begin{tabular}{|c|c|c|c|}
\hline $\begin{array}{c}\text { Nutrient } \\
\text { Condition }\end{array}$ & $\begin{array}{c}\text { \%DOC Removal } \\
\text { (Phase 1) }\end{array}$ & $\begin{array}{c}\text { \%DOC Removal } \\
\text { (Phase 2) }\end{array}$ & $\begin{array}{c}\text { \%DOC Removal } \\
\text { (Phase 3) }\end{array}$ \\
\hline 1 - NS A & $13.5 \pm 9.3$ & $32.2 \pm 10.9$ & $33.5 \pm 14.7$ \\
\hline 2 - NS B & $13.7 \pm 9.3$ & $27.5 \pm 11.3$ & $32.9 \pm 14.6$ \\
\hline 3 - NL & $15.2 \pm 8.7$ & $22.9 \pm 9.5$ & $21.3 \pm 12.4$ \\
\hline
\end{tabular}

A marked increase in DOC removal is observed for all columns from Phase 1 to Phase 2 as can be seen in Figure 5.7. For the nutrient supplemented columns (1 - NS A and 2 - NS B), this increase can be attributed to an increase in $\mathrm{C}: \mathrm{N}: \mathrm{P}$ ratio and new backwash procedure. However, the increase observed for nutrient limited column (3 - NL) is interesting.

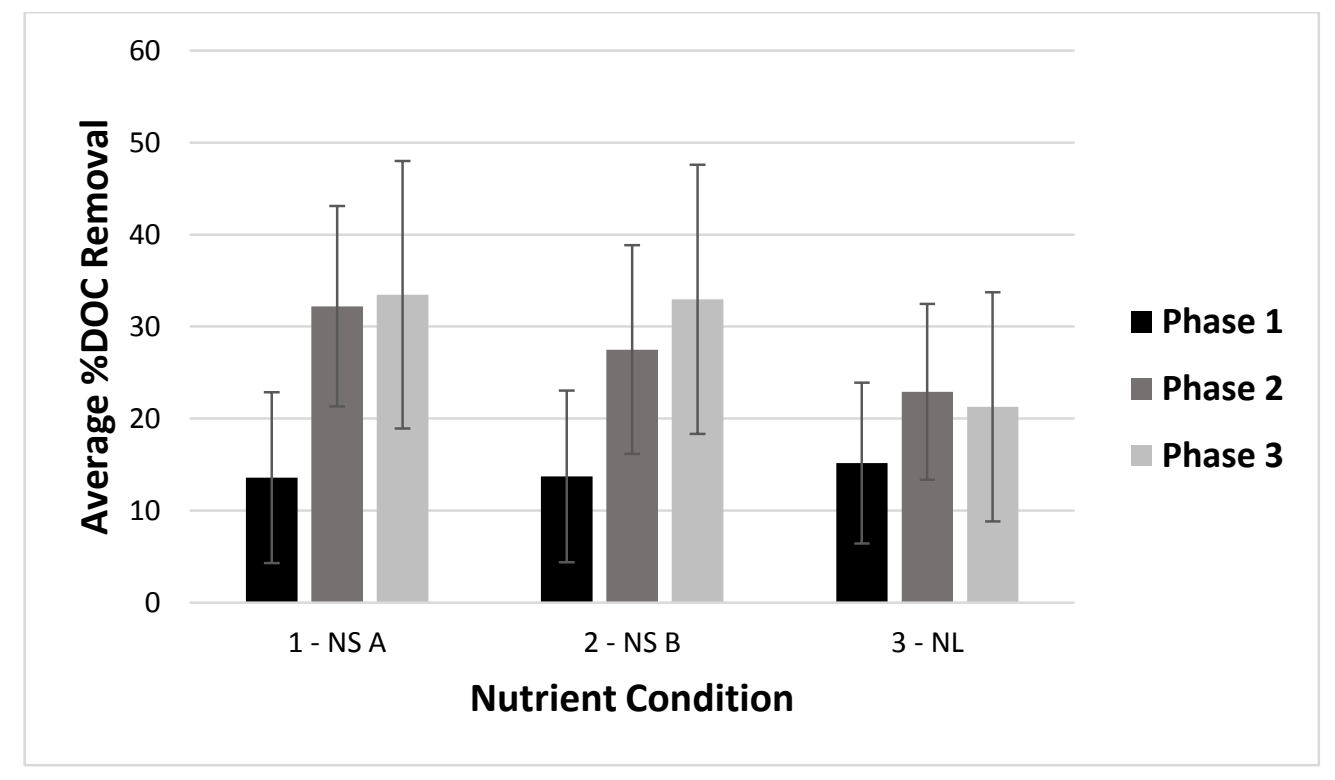

Figure 5.7: Average \%DOC removal for all columns over Phase 1, 2 and 3

It provides an indication that the conditioning/acclimation phase for nutrient limited biofilters is perhaps longer than that observed for biofilters receiving a more balanced 
nutrient ratio. Further, the data seems to highlight the importance of appropriate backwash strategies when dealing with a nutrient limited water source.

DOC removals for 1 - NS A and 2 - NS B did not change significantly from Phase 2 to Phase 3. As well, 2 - NS B (C:N:P = 100:10:1) appeared to perform at par with 1 - NS A $(\mathrm{C}: \mathrm{N}: \mathrm{P}=25: 5: 1)$. Thus, the $100: 10: 1(\mathrm{w} / \mathrm{w})$ ratio was thought to be adequate to achieve optimal DOC removal. This would be lower than the suggested C:N:P ratio of 39:4.5:1 on a weight basis (100:10:1 on a mol basis) (LeChevallier et al., 1991). However, more studies should be carried over a wider range of raw water conditions in order to determine the reproducibility of these results.

Furthermore, it is believed here that nutrient uptake in the active portion of the biofilm is limited to a certain amount which would be required by the bacterial community to perform various metabolic functions. Nutrient dosing beyond a certain ratio would thus cease to be beneficial. Indeed, previous research by Romani et al. (2004) has shown a reduction in extracellular enzyme activity ( $\beta$-glucosidase and phosphatase) within a biofilm when increasing the N:P ratio from 4.34 to 1.46 on a w/w basis. It should be noted however that this study was carried out under carbon limited conditions. If a utility were to implement nutrient supplementation, this result could have positive impacts from a cost perspective. SUVA values were consistently higher in the effluent samples for all observed columns in Phase 3 as can be seen from Table 5.7. This would be consistent with what was observed in Phase 2. Thus, it would be fair to conclude that SUVA removal is not indicative of filter performance when carbon sources do not contain aromatic compounds. While this may not have implications for a larger utility treating surface/ground water (traditional source 
waters would be rich in aromatic NOM content), it could have potential implications for future studies conducted using synthetic raw water similar to this.

Table 5.7: Average influent, effluent UVA254 and SUVA254 values for Phase 3

\begin{tabular}{|c|c|c|c|c|}
\cline { 2 - 5 } \multicolumn{1}{c|}{} & \multicolumn{2}{c|}{ UVA254 } & \multicolumn{2}{c|}{ SUVA254 $\left.\mathbf{c m}^{-1}\right)$} \\
\hline $\begin{array}{c}\text { Nutrient } \\
\text { Condition }\end{array}$ & $\begin{array}{c}\text { Influent } \\
\text { Average } \pm \text { SD }\end{array}$ & $\begin{array}{c}\text { Effluent } \\
\text { Average } \pm \text { SD }\end{array}$ & $\begin{array}{c}\text { Influent } \\
\text { Average } \pm \text { SD }\end{array}$ & $\begin{array}{c}\text { Effluent } \\
\text { Average } \pm \text { SD }\end{array}$ \\
\hline 1 - NS A + K & $0.07 \pm 0.01$ & $0.07 \pm 0.01$ & $0.75 \pm 0.15$ & $1.17 \pm 0.49$ \\
\hline 2 - NS B & $0.07 \pm 0.01$ & $0.07 \pm 0.01$ & $0.74 \pm 0.17$ & $1.09 \pm 0.37$ \\
\hline $3-$ NL & $0.08 \pm 0.01$ & $0.07 \pm 0.01$ & $0.77 \pm 0.21$ & $0.90 \pm 0.22$ \\
\hline
\end{tabular}

\subsubsection{Total Nitrogen (TN) Removal}

Nitrogen is found in several undesirable forms in surface and ground water such as ammonia, nitrites and nitrates. For ammonia removal, utilities often employ the technique of breakpoint chlorination. However, this can be cost inhibitive (Wert et al., 2008). If nitrification can be achieved in drinking water biofilters, simultaneous removal of organics and nitrogen would prove beneficial from a cost perspective.

Currently, there exists a lack of information in literature with regards to the impact of C:N:P ratios on TN removal through biofiltration columns. Table 5.8 shows the variation in influent TN values over the course of Phase 2.

Table 5.8: Average, maximum and minimum influent TN values for Phase 2

\begin{tabular}{|c|c|c|c|}
\hline \multirow{2}{*}{ Nutrient Condition } & \multicolumn{3}{|c|}{ Total Nitrogen (mg/L) } \\
\cline { 2 - 4 } & Average \pm SD & Maximum & Minimum \\
\hline 1 - NS A & $0.58 \pm 0.28$ & 1.369 & 0.364 \\
\hline 2 - NS B & $0.59 \pm 0.27$ & 1.421 & 0.394 \\
\hline 3 - NL & $0.44 \pm 0.06$ & 0.548 & 0.365 \\
\hline
\end{tabular}


From Figure 5.8, it can be seen that 2 - NS B showed the highest \%TN removal over both Phase 2 and 3. Over the course of Phase 2, there were several instances where TN effluent values were observed to be higher than influent values for 1 - NS A. This led to a reduction in the average \% TN removal for 1 - NS A. Phospholipid analysis of biomass conducted for the top $(5 \mathrm{~cm})$ and middle $(18 \mathrm{~cm})$ of the columns showed fluctuations over the course of Phase 2 (Section 5.4.3.2). It is possible that as a result of these fluctuations, the TN values in the effluent were higher. Biofilms are encased in complex matrices known as extracellular polymeric substances (EPS) (Flemming and Wingender, 2010). The EPS performs many functions and has many components such as polysaccharides, proteins, DNA, etc. which contain nitrogen (Flemming and Wingender, 2010). Thus, variations in phospholipid counts (indicating shearing of biofilm into the effluent) could potentially result in higher TN values at the effluent.

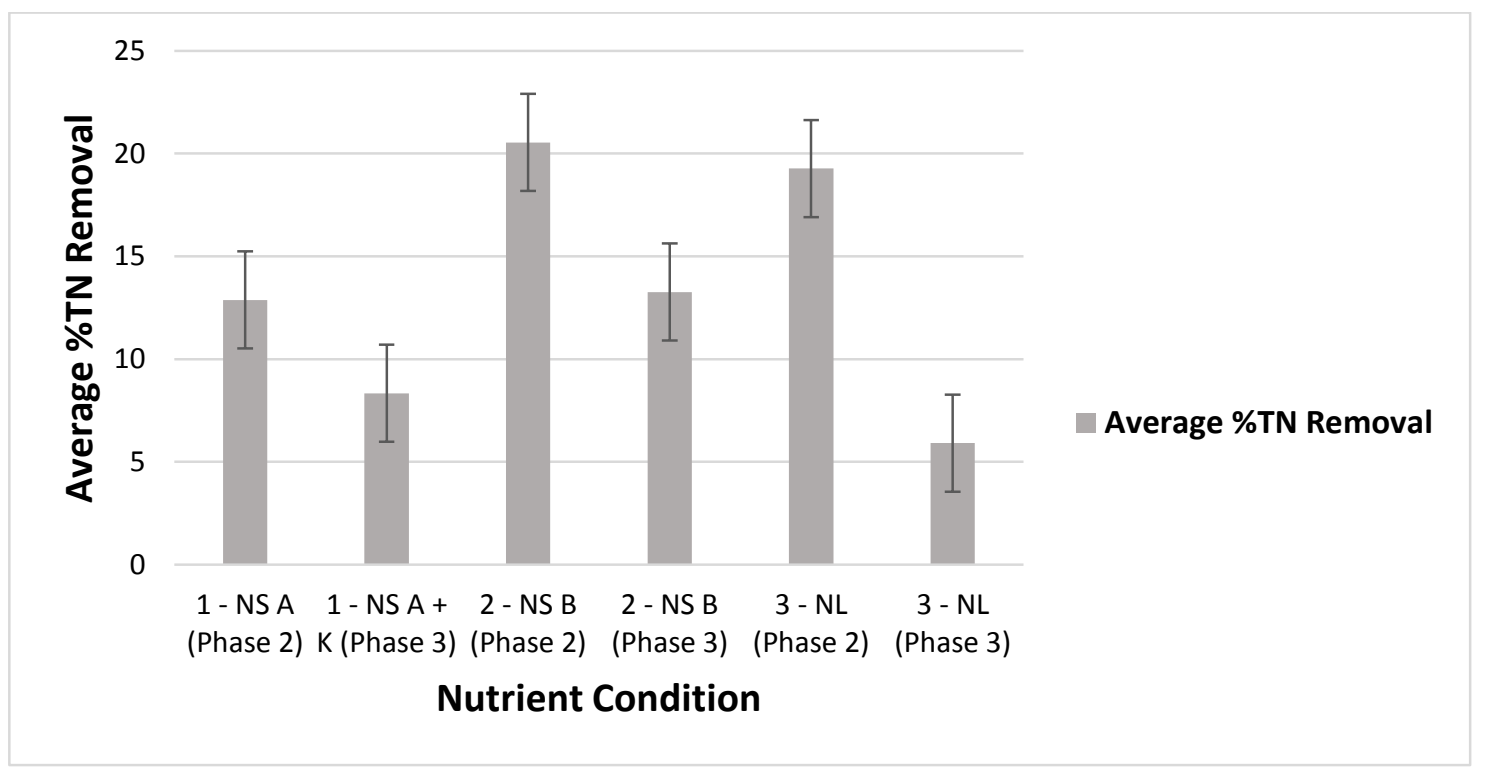

Figure 5.8: Average \%TN removal for Phase 2, 3

Statistical analysis of \% TN removal showed no statistical difference between the columns $(\alpha=0.05)$ in Phase 2 and 3 respectively once steady state conditions were reached. 
However, a reduction in \% TN removals was observed for all columns in Phase 3. A major shedding event for 1 - NS A + K in Phase 3 could be a potential reason for the drop in TN removal for the column with potassium enhancement. It is possible that the portion of the biofilm which was sloughed contained the active biofilm which readily metabolized total nitrogen. However, the reasoning for the reduction in 2 - NS B and 3 - NL is unclear. The raw water conditions remained constant for these between Phase 2 and Phase 3.

It should be remembered that removal of ammonia takes place through a two-step process (Wert et al., 2008). First, Nitrosomonas bacteria convert ammonia to nitrite followed by conversion of nitrite to nitrate by Nitrobacter bacteria. Over the course of this study, total nitrogen was being measured which is the sum of total kjeldahl nitrogen and nitrate, nitrite. In Phase 3, it is quite possible that a majority of the ammonia was converted to nitrate which resulted in higher effluent TN values. Similar results were seen by Wert et al. (2008). They observed full nitrification after approximately 170 days of operation and found effluent nitrate values higher than raw water nitrate.

Temperature has been found to be an important factor for achieving optimal nitrification in drinking water biofilters (Andersson et al., 2001). It is possible that the overall decrease in temperature from Phase 2 to Phase 3 was responsible for the reduction in \%TN removals observed in all columns.

\subsubsection{Phospholipid Analysis}

Average phospholipid counts for 1 - NS A showed a decrease from $170 \mathrm{nmol} \mathrm{P} / \mathrm{g}$ media to $142 \mathrm{nmol} \mathrm{P/g}$ media from Phase 2 to Phase 3 . This was primarily due to a shedding event which was encountered potentially as a result of potassium addition. No discernible effect 
was observed for the other columns between Phase 2 and 3. Average phospholipid counts for the top $(5 \mathrm{~cm})$ and middle $(18 \mathrm{~cm})$ of each column over Phase 2 and 3 and are shown in Figure 5.9.

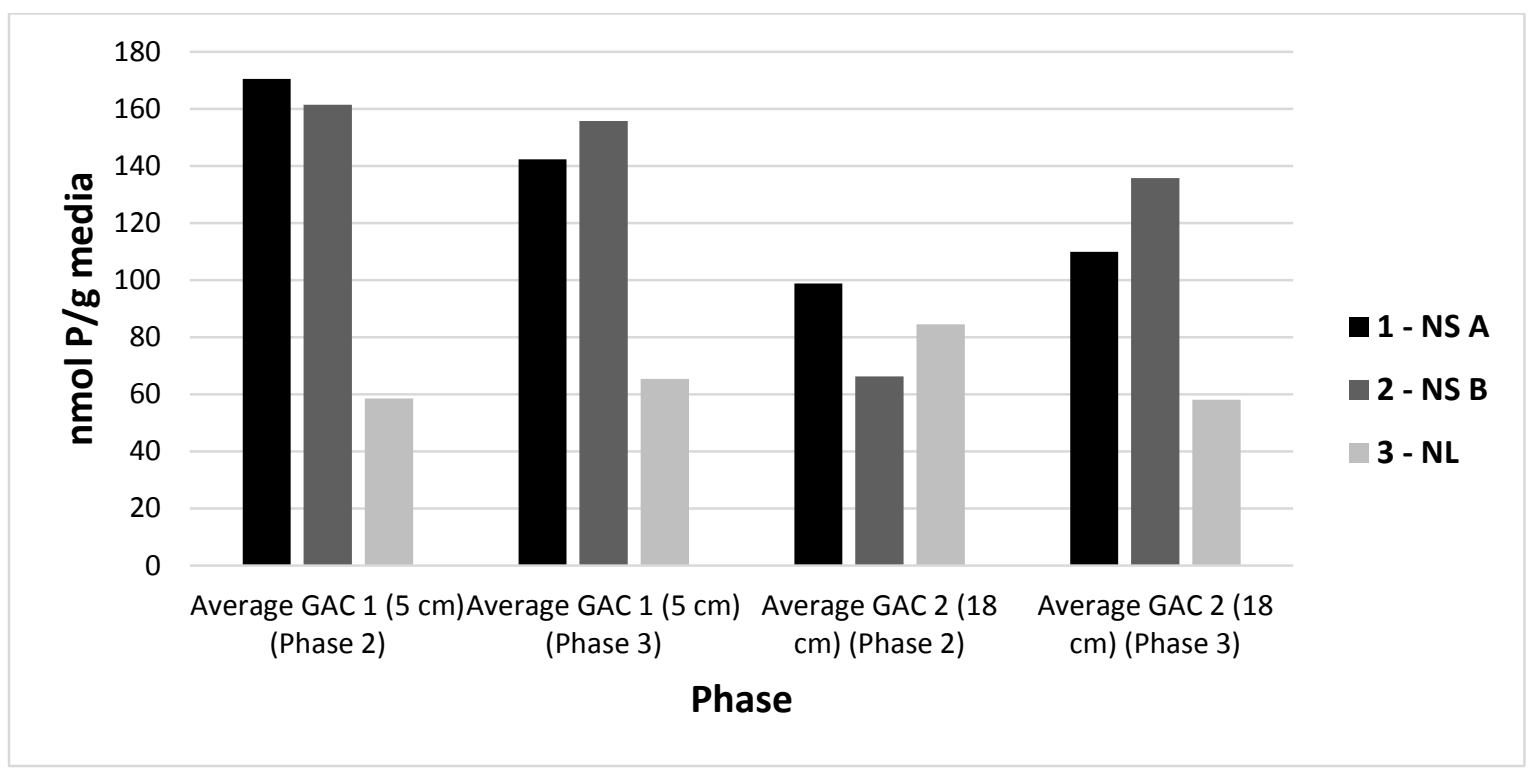

Figure 5.9: Average top and middle phospholipid counts for Phase 2 and 3

\subsubsection{Impact of Potassium on Biomass Concentration}

Although potassium enhancement did not affect DOC removals, it could have been potentially responsible for a major sloughing event. Figure 5.10 displays the phospholipid counts for 1 - NS A + K. ATP concentrations for $1-\mathrm{NS}$ A + K have been shown in Figure 5.11. ATP and phospholipid analysis of biomass indicate a potential shedding event around day 282.

This would be in contrast with the ATP analysis for 2 - NS B and 3 - NL (Table 5.9) which appeared to be fairly stable. 


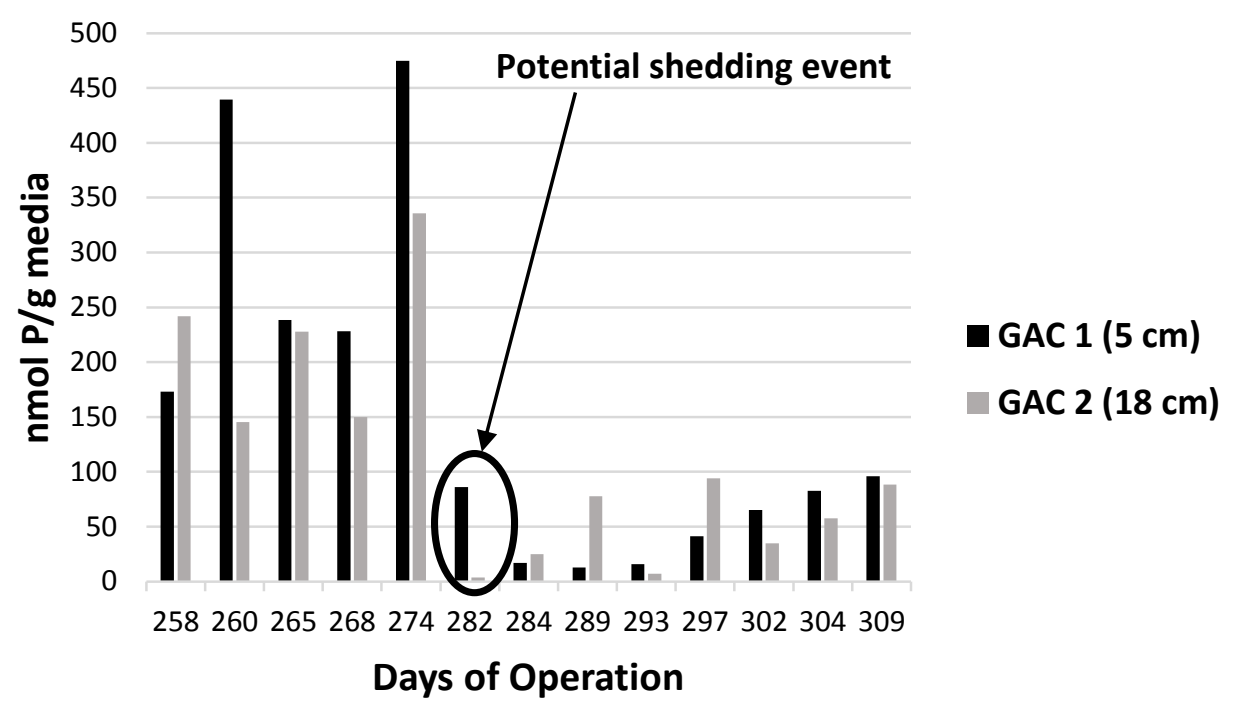

Figure 5.10: Phospholipid analysis of biomass for 1 - NS A + K

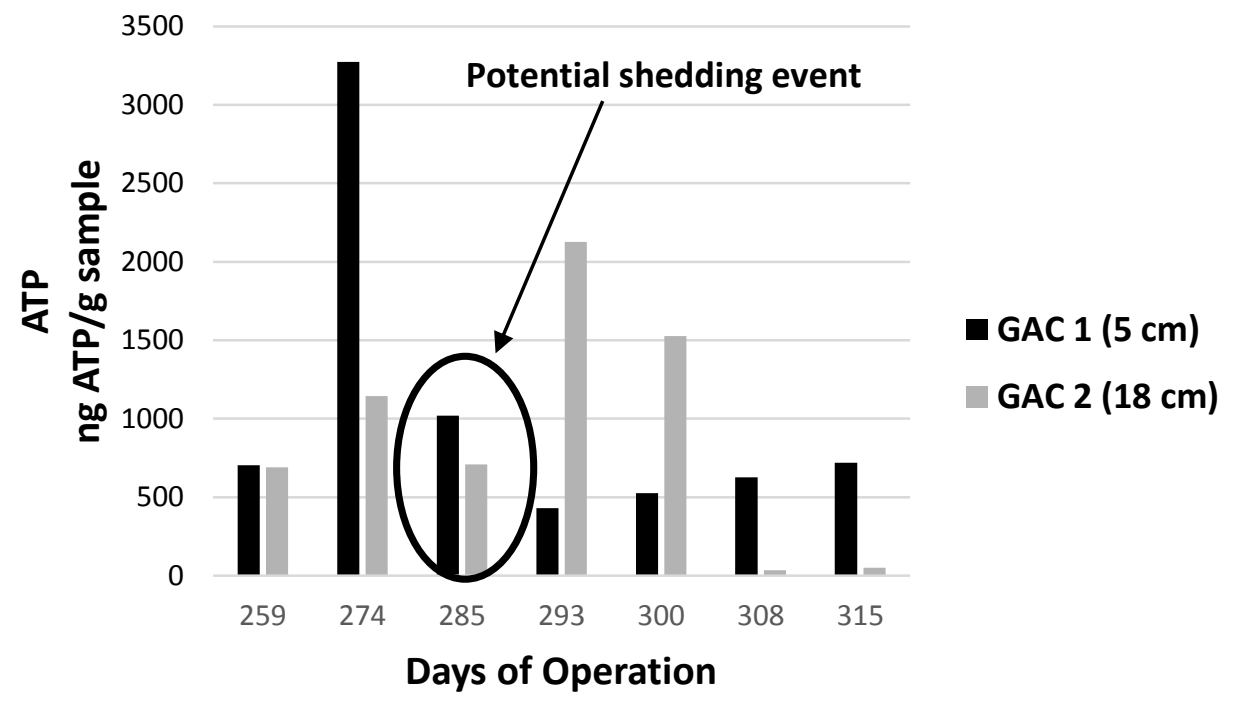

Figure 5.11: ATP analysis of biomass for $1-\mathrm{NS} \mathrm{A}+\mathrm{K}$

As seen in Figure 5.10, the addition of potassium had a positive impact on phospholipid biomass growth initially. Indeed, statistical analysis $(\alpha=0.05)$ of average phospholipid values prior to the shedding event show a statistical difference $(p=0.01)$ when compared 
with the phospholipid counts for 1 - NS A from Phase 2. Thus, potassium supplementation did have a positive impact on biomass growth.

However, as the potential shedding event indicates, perhaps the quantity of potassium being dosed in this study far exceeded the requirements of a bacterial cell in a drinking water treatment scenario. Brdjanovic et al. (1996) provide a potassium to phosphorous mol ratio ( 1 mol of potassium per mole of phosphorous) on which this study is based. It should be noted however that that particular study was conducted on wastewater systems which are known to have higher organic loading than drinking water systems.

Table 5.9: ATP values for 2 - NS B and 3 - NL at $5 \mathrm{~cm}$ and $18 \mathrm{~cm}$ depths

\begin{tabular}{|c|c|c|c|c|}
\hline \multirow{2}{*}{$\begin{array}{c}\text { Days of } \\
\text { Operation }\end{array}$} & $\begin{array}{c}|c| \\
\text { GAC 1 (5 cm) } \\
\text { (ng ATP/g sample) }\end{array}$ & $\begin{array}{c}\text { GAC 2 (18 cm) } \\
\text { (ng ATP/g } \\
\text { sample) }\end{array}$ & $\begin{array}{c}\text { GAC 1 (5 cm) } \\
\text { (ng ATP/g } \\
\text { sample) }\end{array}$ & $\begin{array}{c}\text { GAC 2 (18 cm) } \\
\text { (ng ATP/g } \\
\text { sample) }\end{array}$ \\
\hline 259 & $7.03 \times 10^{2}$ & $0.66 \times 10^{2}$ & $2.66 \times 10^{2}$ & $1.97 \times 10^{2}$ \\
\hline 274 & $11.99 \times 10^{2}$ & $16.52 \times 10^{2}$ & $1.24 \times 10^{2}$ & $2.49 \times 10^{2}$ \\
\hline 285 & $9.78 \times 10^{2}$ & $11.23 \times 10^{2}$ & $2.12 \times 10^{2}$ & $2.97 \times 10^{2}$ \\
\hline 293 & $16.88 \times 10^{2}$ & $17.6 \times 10^{2}$ & $2.39 \times 10^{2}$ & $2.64 \times 10^{2}$ \\
\hline 300 & $12.48 \times 10^{2}$ & $10.99 \times 10^{2}$ & $2.09 \times 10^{2}$ & $2.49 \times 10^{2}$ \\
\hline 308 & $4.96 \times 10^{2}$ & $0.86 \times 10^{2}$ & $0.6 \times 10^{2}$ & $0.16 \times 10^{2}$ \\
\hline 315 & $5.85 \times 10^{2}$ & $1.99 \times 10^{2}$ & $1.05 \times 10^{2}$ & $0.82 \times 10^{2}$ \\
\hline
\end{tabular}




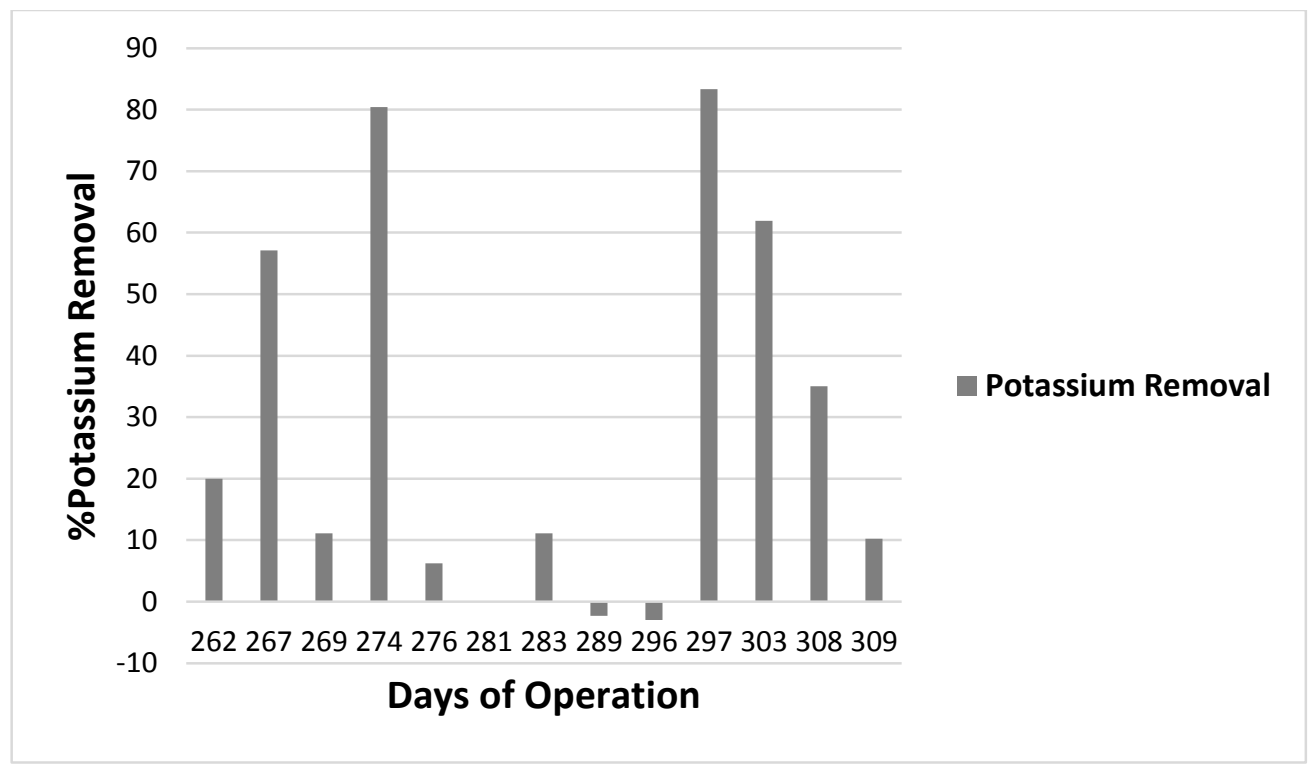

Figure 5.12: Potassium removal for $1-\mathrm{NS}$ A + K

Figure 5.12 shows around day 281 that $0 \%$ removal of potassium was observed. Following this, negative removals (indicating higher potassium concentrations in filter effluent) were encountered. From Figure 5.10 and Figure 5.12, we see that this corresponds to the time when the shedding event was observed. Around day 297 we see an increase in potassium removal which would correlate to the increase in biomass observed during this period for $1-\mathrm{NS} A+\mathrm{K}$.

Potassium is found within cell walls and plays a major role in regulating the internal osmotic pressure of a cell as well as enzyme activation (Ingraham et al., 1983). Anderson et al. (2008) sought to monitor potassium as a potential surrogate for endotoxin release following filter shut down. They observed an increase in potassium concentrations at the effluent following periods of 18 hour shut downs. They reason that within that shut down period, the environment within the biofilter changed to one where the bacteria needed to release potassium to maintain internal osmotic pressure. Cell lysis is also provided as a potential reason for this increase in effluent potassium. Thus, it is possible here that 
potassium accumulation reached a stage where it hindered the physiological and chemical balances within the cell wall, resulting in cell lysis.

\subsection{Conclusions}

The impacts of nitrogen, phosphorous and potassium supplementation on organics removal in drinking water biofilters were studied. In addition, a comparison of water wash only and air-scour assisted backwash were studied with a biofilter under nutrient limited conditions.

Nutrient limited conditions (C:N:P $=546: 24: 1$ on a w/w basis) resulted in DOC removals of $15.3 \%$ under water only backwash conditions and approximately $23 \%$ under air-assisted backwash conditions. Nitrogen and phosphorous were then supplemented to two of the three columns with C:N:P ratios of 25:5:1 and 100:10:1 on a w/w basis. Following nutrient supplementation, DOC removals of $32.2 \%$ and $27.5 \%$ were observed for the two nutrient supplementary columns. This reflected an increase of approximately $19 \%$ and $9 \%$ respectively. No clear correlation could be drawn between phospholipid counts of biomass and ATP concentrations with DOC removal. It should be noted that phospholipid analysis is not necessarily representative of the active biomass (Wang et al., 1995). ATP is only found within living, viable cells (Caprita et al., 2006). Hence ATP is perhaps a better indicator of viable biomass contributing to DOC removal.

$\mathrm{TN}$ removals were found to decrease for all columns from Phase 2 to Phase 3. However, this may be due to an increase in nitrate concentration through the filter as full nitrification occurred. Future analysis should include nitrite, nitrate and ammonia analysis to further assess nitrification profiles within the system. 
Potassium supplementation did not improve DOC removals, although it may have contributed to a bacterial sloughing event in the biofilters. It is possible that the potassium to phosphorous mol ratio used in this study exceeded the demands of drinking water biofilters and proved detrimental to biomass growth beyond a point. Future research should consider an alternative ratio of potassium to phosphorous as used in this study.

\section{References}

1. Anderson W.B., Mayfield C.I. and Huck P.M. 2008 Endotoxin release from biologically active bench-scale drinking water anthracite/sand filters. J. Water Supply Res. Technol. Aqua, 57(8), 585-597.

2. Andersson A., Laurent P., Kihn A., Prévost M. and Servais P. 2001 Impact of temperature on nitrification in biological activated carbon (BAC) filters used for drinking water treatment. Water Research, 35(12), 2923-2934.

3. Basu O.D. and Huck P.M. 2004 Integrated biofilter-immersed membrane system for the treatment of humic waters. Water Research, 38(3), 655-662

4. Boon N., Pycke B.F., Marzorati M. and Hammes F. 2011 Nutrient gradients in a granular activated carbon biofilter drives bacterial community organization and dynamics. Water Research, 45(19), 6355-6361.

5. Brdjanovic D., Hooijmans C.M., van Loosdrecht M.C.M., Alaerts G.J. and Heijnen J.J. 1996 The dynamic effects of potassium limitation on biological phosphorous removal. Water Research, 30(10), 2323-2328.

6. Caprita R., Caprita A., Vintila T. and Ilia G. 2006 The ATP assay, a method for measuring biological activity in industrial water. Revue Roumaine de Chimie, 51(10), 1031-1036. 
7. Emelko M.B., Huck P.M., Coffey B.M. and Smith E.F. 2006 Effects of media, backwash, and temperature on full-scale biological filtration. Journal American Water Works Association, 98(12), 61-73.

8. Flemming H.C. and Wingender, J. 2010 The biofilm matrix. Nature Reviews Microbiology, 8(9), 623-633.

9. Fonseca A.C., Summers R.S. and Hernandez M.T. 2001 Comparative measurements of microbial activity in drinking water biofilters. Water Research,35(16), 3817-3824.

10. Ghosh U., Weber A.S., Jensen J.N. and Smith J.R. 1999 Granular activated carbon and biological activated carbon treatment of dissolved and sorbed polychlorinated biphenyls. Water Environment Research, 71(2), 232-240.

11. Granger H.C., Stoddart A.K. and Gagnon G.A. 2014 Direct biofiltration for manganese removal from surface water. Journal of Environmental Engineering, 140(4). 04014006-1-04014006-8

12. Ingraham J. L., Maaløe O. and Neidhardt F. C. 1983 Growth of the Bacterial Cell. Sinauer Associates, Sunderland, MA.

13. Kong, L., Zhang, X., \& Wang, Z. (2006). Pilot plant study on ozonation and biological activated carbon process for drinking water treatment. Journal of Environmental Sciences, 18(2), 232-235.

14. Lauderdale C., Chadik P., Kirisits M.J. and Brown J. 2012 Engineered Biofiltration: Enhanced Biofilter Performance through Nutrient and Peroxide Addition. Journal American Water Works Association, 104(5), E298-E309. 
15. LeChevallier M.W., Schulz W. and Lee R.G. 1991 Bacterial nutrients in drinking water. Applied and Environmental Microbiology, 57(3), 857-862.

16. Liao X., Chen C., Wang Z., Wan R., Chang C.H., Zhang X. and Xie S. 2013 Changes of biomass and bacterial communities in biological activated carbon filters for drinking water treatment. Process Biochemistry, 48(2), 312-316.

17. Moll D.M., Summers R.S., Fonseca A.C. and Matheis W. 1999 Impact of temperature on drinking water biofilter performance and microbial community structure. Environmental Science \& Technology, 33(14), 2377-2382.

18. Nishijima W., Shoto E. and Okada M. 1997 Improvement of biodegradation of organic substance by addition of phosphorous in biological activated carbon. Water Science and Technology, 36(12), 251-257.

19. Romani A.M., Giorgi A., Acuna V. and Sabater S. 2004 The influence of substratum type and nutrient supply on biofilm organic matter utilization in streams. Limnology and Oceanography, 49(5), 1713-1721.

20. Rosenberg H. 1987 Phosphate transport in prokaryotes. In: Ion Transport in Prokaryotes, B.P. Rosen (ed.), 1st edn, Academic Press, Chicago, USA, pp. 85130.

21. Sang J., Zhang X., Li L. and Wang Z. 2003 Improvement of organics removal by bio-ceramic filtration of raw water with addition of phosphorous. Water Research, 37(19), 4711-4718.

22. Sakoda A., Wang J. and Suzuki M. 1996 Microbial activity in biological activated carbon bed by pulse responses. Water Science and Technology, 34(5), 213-222. 
23. Simpson D. R. 2008 Biofilm processes in biologically active carbon water purification. Water Research, 42(12), 2839-2848.

24. Sohn J., Amy G. and Yoon Y. 2007 Process-train profiles of NOM through a drinking water treatment plant. Journal American Water Works Association, 99(6) $145-153$.

25. Standard Methods for the Examination of Water and Wastewater 2012 22nd edn, American Public Health Association/American Water Works Association/Water Environment Federation, Washington DC, USA.

26. Takeuchi Y., Mochidzuki K., Matsunobu N., Kojima R., Motohashi H. and Yoshimoto S. 1997 Removal of organic substances from water by ozone treatment followed by biological activated carbon treatment. Water Science and Technology, 35(7), 171-178.

27. Tchobanoglous G. and Burton F.L. 1991 Wastewater Engineering: Treatment Disposal and Reuse, Mc-Graw Hill, New York, USA.

28. Tchobanoglous, G., Burton, F.L. and Stensel H.D. 2003 Wastewater Engineering: Treatment and reuse, McGraw Hill, New York, USA

29. Urfer D. and Huck P.M. 2001 Measurement of biomass activity in drinking water biofilters using a respirometric method. Water Research, 35(6), 1469-1477.

30. Wang J.Z., Summers R.S. and Miltner R.J. (1995). Biofiltration performance: part 1, relationship to biomass. Journal American Water Works Association, 87(12), 5563.

31. Weishaar J.L., Aiken, G.R., Bergamaschi, B.A., Fram, M.S., Fujii R. and Mopper K. 2003 Evaluation of specific ultraviolet absorbance as an indicator of the 
chemical composition and reactivity of dissolved organic carbon. Environmental Science \& Technology, 37(20), 4702-4708.

32. Wert E.C., Neemann J.J., Rexing D.J. and Zegers R.E. 2008 Biofiltration for removal of BOM and residual ammonia following control of bromate formation. Water Research, 42(1), 372-378.

33. Yapsakli K. and Çeçen F. 2010 Effect of type of granular activated carbon on DOC biodegradation in biological activated carbon filters. Process Biochemistry, 45(3), $355-362$. 


\section{Conclusions}

Biofiltration is a sustainable technology that can be employed for removing NOM present in a water source. Biodegradation of NOM by the biofilm attached to the biofilter media is a potential advantage of promoting biomass growth. However, current filtration design practices do not take biological growth into consideration and instead choose to focus on various physical design parameters such as EBCT, backwashing strategy and hydraulic loading. Thus, it is possible that the system can be further optimized for DOC removal by promoting biological growth. Although previous studies have shown that phosphorous supplementation has proven to be beneficial for organics removal, the number of studies are limited. Hence, the effect of nitrogen and phosphorous supplementation for organics removal under different C:N:P ratios was investigated in this study.

At first, a preliminary investigation into the effects of nutrient limitation was carried out at the BWTP in Ottawa, ON, Canada. The pilot scale multi-stage filtration system consisted of slow sand filtration and BAC filtration in two parallel trains, each with pre-ozonation. In the lab scale study, three dual media biofiltration columns were used. This study was split into three phases. Phase 1 involved biofilter conditioning where nutrient limited conditions observed at the preliminary site were employed. In Phase 2, nitrogen and phosphorous were supplemented to obtain C:N:P ratios of 25:5:1 and 100:10:1 on a w/w basis. Finally, Phase 3 consisted of potassium supplementation to assess its impact on organics removal. 


\subsection{Preliminary Phase Conclusions}

The nutrient limited conditions observed at the preliminary site $(\mathrm{C}: \mathrm{N}: \mathrm{P}=546: 24: 1$ on a w/w basis) were not ideal for optimal DOC removal. Indeed, \%DOC removals for SSF, BAC 1 and BAC 2 were $7.85 \%, 10.29 \%$ and 8.38\% respectively. Due to a mechanical problem with the ozone generator, ozone dosage could not be increased beyond $1.55 \mathrm{mg}$ $\mathrm{O}_{3} / \mathrm{mg}$ DOC. It was believed this problem had been fixed and the ozone dosage was increased to $3 \mathrm{mg} \mathrm{O} 3 / \mathrm{mg}$ DOC. However, ozone leaked into the system and resulted in residuals of $1.8 \mathrm{mg} \mathrm{O}_{3} / \mathrm{L}$ and $2.17 \mathrm{mg} \mathrm{O}_{3} / \mathrm{L}$ for Train 1 and Train 2 respectively. This resulted in a sharp decrease in ATP values for the two BAC filters. However, DOC removals appeared to be relatively unaffected. Upon increasing ozone dosage, SUVA removals were found to increase. However, sustained work at the higher ozone dosage could not be carried out due to mechanical difficulties. This would indicate that a higher ozone dosage would be necessary when dealing with nutrient limited source waters. As well, the backwash procedure being employed for the two BAC columns was a water only backwash using tap water with a residual chlorine concentration of $0.17 \mathrm{mg} / \mathrm{L}$. Past research has shown using chlorinated waters for backwash is detrimental to biomass growth. As well, a water only backwash was deemed inadequate and an air scour assisted collapse pulsing procedure was employed for the lab scale study.

\subsection{Phase 1 Conclusions}

Columns achieved steady state DOC removals after 50 days of conditioning at nutrient limited conditions. A water only backwash procedure with biofilter effluent was employed. Average DOC removals for this phase were $13.67 \%, 13.52 \%$ and $15.33 \%$ for the three columns at the end of Phase 1 . A t-test conducted on \%DOC removals showed no statistical 
differences. These removals were higher than what was observed at the preliminary site. However, given the carbon sources used in the lab scale study (glyoxal, formic acid, acetic acid) which are readily biodegradable, this was to be expected. Once columns were conditioned, Phase 2 was implemented.

\subsection{Phase 2 Conclusions}

The effects of nitrogen and phosphorous supplementation on DOC removal were investigated in this phase of the study. Nitrogen and phosphorous were dosed to two of the three columns to make up C:N:P ratios of 25:5:1 (1 - NS A) and 100:10:1 (2 - NS B) on a w/w basis. One column was kept nutrient limited $(3-\mathrm{NL})$ to serve as the control. An air scour assisted backwash was employed for this phase.

Nutrient enhancement resulted in a significant increase in DOC removal. Average removals improved by $18.5 \%$ for 1 - NS A and $14 \%$ for 2 - NS B and were statistically significant at the $95 \%$ confidence level. Thus, nutrient supplementation did have a positive impact on DOC removal. Interestingly, \%DOC removal for $3-\mathrm{NL}$ also improved by approximately $8 \%$ despite the nutrient limited conditions. This would lend further evidence to support the theory that backwash procedures employing a water only wash are inadequate for cleaning the biofilters. Thus, backwashing is an important parameter that needs to be optimized in order to ensure maximum removal of DOC.

Phospholipid analysis of biomass was carried out at $5 \mathrm{~cm}$ and $18 \mathrm{~cm}$ depths in the filters. Nutrient supplementation was not found to affect phospholipid counts in the biofilters. Indeed, upon comparing the average phospholipid counts for all columns, no statistically significant difference was observed $(\alpha=0.05)$. As well, phospholipid biomass values did 
not correlate well with DOC removal. Despite low phospholipid counts, \%DOC removals in the $30 \%$ range were observed. There is an inconsistency with this relationship in literature as well. It bears noting that bacterial cells contain phospholipids within the cell membrane. Dead cells contain phospholipids as well which are released upon cell lysis. Thus, it is possible that phospholipid counts may not be representative of the active biomass community that consumes organics and ATP measurements may be more representative.

\subsection{Phase 3 Conclusions}

Biofilms are made up of complex matrices and not much is understood about their metabolic functions. It is therefore possible that factors other than nitrogen and phosphorous may be responsible for promoting biomass growth and activity. In Phase 3, a relatively novel technique was studied. Besides nitrogen and phosphorous, potassium was added to $1-\mathrm{NS}$ A in a $1 \mathrm{~mol} \mathrm{~K} / \mathrm{mol} \mathrm{P}$ ratio to assess its impacts on organics removal. As well, average water temperature was kept at $11{ }^{\circ} \mathrm{C}$ for this phase of the study.

Total nitrogen removals were monitored over the course of Phase 2 and 3. \%TN removals saw a reduction of approximately $11 \%, 8 \%$ and $10 \%$ for $1-\mathrm{NS}$ A, $2-\mathrm{NS}$ B and $3-\mathrm{NL}$ respectively between Phase 2 and 3. In this study, individual components of TN were not being monitored. It is known that TN comprises total kjeldahl nitrogen and nitrates and nitrites. It is possible that as a result of full nitrification taking place in the filters, the effluent nitrate content was higher than the influent nitrate concentration. This would skew the TN removal values. Further, temperature is known to play a significant role in nitrification in drinking water biofilters. The reduction in temperature to $11^{\circ} \mathrm{C}$ over the course of Phase 3 could have been a potential reason for the reduction in TN removals. 
Potassium supplementation showed no discernible effect on DOC removal. However, potassium supplementation did have an impact on the phospholipid counts for $1-\mathrm{NS}$ A + K. A statistically significant increase $(\alpha=0.05)$ was observed when comparing the average phospholipid counts between Phase 2 and 3. Beyond this, a sloughing event was observed which is confirmed by the phospholipid and ATP profiles for $1-\mathrm{NS}$ A + K. Potassium analysis at this time indicates $0 \%$ removal followed by periods of negative removal (higher potassium in biofilter effluent). Potassium is present in cell walls and regulates the osomotic pressure within cells. It is believed that the potassium to phosphorous ratio being employed in this study far exceeded the demands of bacteria in drinking water biofilters. Indeed, this ratio was based on a study conducted using wastewater which is known to have a higher organic loading than drinking water systems.

\subsection{Overall Conclusions and Future Work}

Nutrient limited conditions coupled with water only backwashing of the biofilters resulted in inconsistent DOC removals at both the lab scale and pilot scale. A phosphorous limited C:N:P ratio of 546:24:1 on a w/w basis was thus deemed inadequate for achieving optimal DOC removal. Nitrogen and phosphorous supplementation improved DOC removal by $18.5 \%$ and $14 \%$ for 1 - NS A and 2 - NS B respectively. Also, the positive effect of an air scour assisted backwashing procedure was observed in the nutrient limited control column which resulted in an increase in DOC removal by approximately $8 \%$.

Although potassium supplementation did not positively impact DOC removal, its effect on biomass development was seen clearly. An initial rise in the quantity of biomass was followed by a shedding event which may have been caused as a result of potassium addition. It is believed that the potassium being dosed may have been in excess of what 
was required by the biomass; as the potassium dosing was based on a wastewater study. This may have disrupted the internal osmotic balance of the bacterial cells resulting in cell lysis and hence led to a biomass shedding event.

The results obtained above provide can form an interesting foundation for future work that can be conducted. This can include:

- Checking the reproducibility of the data at cold water temperatures $\left(<5^{\circ} \mathrm{C}\right)$

Temperature is known to play a significant role in dictating the performance of biological filters. A reduction in water temperature is typically accompanied by a drop in DOC removal for drinking water biofilters. Although the mechanism behind the effects of cold water temperatures on drinking water biofilters is not fully understood, nutrient supplementation at cold water temperatures may prove beneficial to the biomass to counteract the effects of cold water temperatures.

- Analysis of ammonia, nitrates and nitrites

Nitrification in drinking water biofilters has not been studied in great detail. If drinking water biofilters could be optimized for simultaneous nitrification and organic carbon removal, this could lead to significant cost savings for the utilities implementing biofiltration. An analysis of ammonia, nitrates and nitrites would allow for studying the development of nitrifiers within a drinking water biofilter.

- Analysis of different K/P ratios

A smaller $\mathrm{K} / \mathrm{P}$ ratio perhaps could prove beneficial in further improving organic carbon removal. Currently, there exists a lack of information regarding the impacts of various micronutrients $\left(\mathrm{K}^{+}, \mathrm{Mg}^{2+}, \mathrm{SO}_{4}{ }^{2-}\right.$, etc. $)$ on the performance of drinking 
water biofilters. Various K/P ratios should be studied to arrive at what may be an optimal ratio for drinking water biofilters.

- Genomic/molecular analysis of biomass

Besides biomass quantification, it would be prudent to develop an understanding of the various species of bacteria present within a biofilter. Genomic classification of the bacterial species could prove helpful as specific strategies could be developed to aid the biofilm community based on the species present. 


\section{References}

1. American Water Works Association \& American Society of Civil Engineers (2012). Water Treatment Plant Design. McGraw Hill, New York

2. Amirtharajah, A. (1993). Optimum backwashing of filters with air scour: a review. Water Science \& Technology, 27(10), 195-211.

3. Anderson, W.B., Mayfield, C.I., \& Huck P.M. (2008). Endotoxin release from biologically active bench-scale drinking water anthracite/sand filters. Journal Water Supply Research Technology Aqua, 57(8), 585-597.

4. Andersson, A., Laurent, P., Kihn, A., Prévost, M., \& Servais, P. (2001). Impact of temperature on nitrification in biological activated carbon (BAC) filters used for drinking water treatment. Water Research, 35(12), 2923-2934.

5. Aslan, S., \& Cakici, H. (2007). Biological denitrification of drinking water in a slow sand filter. Journal of Hazardous Materials, 148(1), 253-258.

6. Basu, O.D., \& Huck, P.M. (2004a). Removal of humic acid by biofiltration. Water Supply, 4(4), 147-154.

7. Basu, O. D., \& Huck, P. M. (2004b). Integrated biofilter-immersed membrane system for the treatment of humic waters. Water Research, 38(3), 655-662.

8. Bekbolet, M., Uyguner, C. S., Selcuk, H., Rizzo, L., Nikolaou, A. D., Meric, S., \& Belgiorno, V. (2005). Application of oxidative removal of NOM to drinking water and formation of disinfection by-products. Desalination, 176(1), 155-166.

9. Black, K.E. (2013). Treatment of Surface Waters using a Multi-Stage Filtration System in Cold Temperature Conditions. PhD Proposal

10. Boon, N., Pycke, B. F., Marzorati, M., \& Hammes, F. (2011). Nutrient gradients in a granular activated carbon biofilter drives bacterial community organization and dynamics. Water Research, 45(19), 6355-6361.

11. Brdjanovic, D., Hooijmans, C. M., Van Loosdrecht, M. C. M., Alaerts, G. J., \& Heijnen, J. J. (1996). The dynamic effects of potassium limitation on biological phosphorous removal. Water Research, 30(10), 2323-2328.

12. Camel, V., \& Bermond, A. (1998). The use of ozone and associated oxidation processes in drinking water treatment. Water Research, 32(11), 3208-3222.

13. Campos, L. C., Su, M. F. J., Graham, N. J. D., \& Smith, S. R. (2002). Biomass development in slow sand filters. Water Research, 36(18), 4543-4551.

14. Cantor, K. P., Lynch, C. F., Hildesheim, M., Dosemeci, M., Lubin, J., Alavanja, M., \& Craun, G. (1998). Drinking Water Source and Chlorination Byproducts I. Risk of Bladder Cancer. Epidemiology, 9(1), 21-28.

15. Caprita, R., Caprita, A., Vintila, T., \& Ilia, G. (2006). The ATP assay, a method for measuring biological activity in industrial water. Revue Roumaine de Chimie, 51(10), 1031-1036. 
16. Chaiket, T., Singer, P. C., Miles, A., Moran, M., \& Pallotta, C. (2002). Effectiveness of coagulation, ozonation, and biofiltration in controlling DBPs. Journal American Water Works Association, 94(12), 81-95.

17. Chaudhary, D. S., Vigneswaran, S., Ngo, H. H., Shim, W. G., \& Moon, H. (2003). Biofilter in water and wastewater treatment. Korean Journal of Chemical Engineering, 20(6), 1054-1065.

18. Crittenden, J.C., Trussell, R.R., Hand, D.W., Howe, K.J., Tchobanoglous, G. (2012). MWH's Water Treatment: Principles and Design. John Wiley \& Sons, Hoboken, New Jersey

19. Dussert, B. W., \& Van Stone, G. R. (1994). The biological activated carbon process for water purification. Water Engineering \& Management, 141(12), 22-24.

20. Eaton, A. D., Clesceri, L. S., Greenberg, A. E., Franson, M. A. H., American Public Health Association., American Water Works Association., \& Water Environment Federation. (1998). Standard methods for the examination of water and wastewater. Washington, DC: American Public Health Association.

21. Emelko, M. B., Huck, P. M., Coffey, B. M., \& Smith, E. F. (2006). Effects of media, backwash, and temperature on full-scale biological filtration. Journal American Water Works Association, 98(12), 61-73.

22. Flemming, H.C., \& Wingender, J. (2010). The biofilm matrix. Nature Reviews Microbiology, 8(9), 623-633.

23. Fonseca, A.C., Summers, R.S., \& Hernandez, M.T. (2001). Comparative measurements of microbial activity in drinking water biofilters. Water Research, 35(16), 3817-3824.

24. Ghosh, U., Weber, A.S., Jensen, J.N., \& Smith, J.R. (1999). Granular activated carbon and biological activated carbon treatment of dissolved and sorbed polychlorinated biphenyls. Water Environment Research, 71(2), 232-240.

25. Granger, H.C., Stoddart, A.K., \& Gagnon, G.A. (2014). Direct biofiltration for manganese removal from surface water. Journal of Environmental Engineering, 140(4). 04014006-1-04014006-8

26. Halle, C., Huck, P. M., Peldszus, S., Haberkamp, J., \& Jekel, M. (2009). Assessing the performance of biological filtration as pretreatment to low pressure membranes for drinking water. Environmental Science \& Technology, 43(10), 3878-3884.

27. Her, N., Amy, G., Plottu-Pecheux, A., \& Yoon, Y. (2007). Identification of nanofiltration membrane foulants. Water Research, 41(17), 3936-3947.

28. Hozalski, R. M., Bouwer, E. J., \& Goel, S. (1999). Removal of natural organic matter (NOM) from drinking water supplies by ozone-biofiltration. Water Science and Technology, 40(9), 157-163.

29. Huck, P.M., Peldszus, S., Halle, C., Ruiz, H., Jin, X., Van Dyke, M., \& MosquedaJimenez, D.B. (2011). Pilot scale evaluation of biofiltration as an innovative pre- 
treatment for ultrafiltration membranes for drinking water treatment. Water Science \& Technology: Water Supply, 11(1), 23-29.

30. Huisman, L and Wood, W.E. (1974). Slow Sand Filtration. World Health Organization, Geneva, Switzerland

31. Ingraham, J. L., Maaløe, O., \& Neidhardt, F. C. 1983 Growth of the Bacterial Cell. Sinauer Associates, Sunderland, MA.

32. Kaarela, O.E., Harkki, H.A., Palmorth, M.R., \& Tuhkanen, T.A. (2014). Bacterial diversity and active biomass in full-scale granular activated carbon biofilters operated at low water temperatures. Environmental Technology, 36(6), 681-692.

33. Kong, L., Zhang, X., \& Wang, Z. (2006). Pilot plant study on ozonation and biological activated carbon process for drinking water treatment. Journal of Environmental Sciences, 18(2), 232-235.

34. Krasner, S. W., Croué, J. P., Buffle, J., \& Perdue, E. M. (1996). Three approaches for characterizing NOM. Journal American Water Works Association, 88(6), 6679.

35. Lauderdale, C., Chadik, P., Kirisits, M.J., \& Brown, J. (2012). Engineered Biofiltration: Enhanced Biofilter Performance through Nutrient and Peroxide Addition. Journal American Water Works Association, 104(5), E298-E309.

36. Laurent, P., Prévost, M., Cigana, J., Niquette, P., \& Servais, P. (1999). Biodegradable organic matter removal in biological filters: evaluation of the CHABROL model. Water Research, 33(6), 1387-1398.

37. LeChevallier, M. W., Schulz, W., \& Lee, R. G. (1991). Bacterial nutrients in drinking water. Applied and Environmental Microbiology, 57(3), 857-862.

38. LeChevallier, M. W., Becker, W. C., Schorr, P., \& Lee, R. G. (1992). Evaluating the performance of biologically active rapid filters. Journal American Water Works Association, 84(4), 136-146.

39. Liao, X., Chen, C., Wang, Z., Wan, R., Chang, C.H., Zhang, X., \& Xie, S. (2013). Changes of biomass and bacterial communities in biological activated carbon filters for drinking water treatment. Process Biochemistry, 48(2), 312-316.

40. Liu, X., Huck, P. M., \& Slawson, R. M. (2001). Factors affecting drinking water biofiltration: Filtration. Journal American Water Works Association, 93(12), 90101.

41. Magic-Knezev, A., \& Van Der Kooij, D. (2004). Optimisation and significance of ATP analysis for measuring active biomass in granular activated carbon filters used in water treatment. Water Research, 38(18), 3971-3979.

42. Manz, D. H., \& Eng, P. (2004). New horizons for slow sand filtration. In: Proceedings of the Eleventh Canadian National Conference and Second Policy Forum on Drinking Water and the Biennial Conference of the Federal-ProvincialTerritorial Committee on Drinking Water, Promoting Public Health Through Safe Drinking Water, Calgary, Alberta (Vol. 3, p. 6). 
43. Matilainen, A., Vepsäläinen, M., \& Sillanpää, M. (2010). Natural organic matter removal by coagulation during drinking water treatment: A review. Advances in Colloid and Interface Science, 159(2), 189-197.

44. McGeehin, M. A., Reif, J. S., Becher, J. C., \& Mangione, E. J. (1993). Case-control study of bladder cancer and water disinfection methods in Colorado. American Journal of Epidemiology, 138(7), 492-501.

45. Miettinen, I. T., Vartiainen, T., \& Martikainen, P. J. (1997). Phosphorous and bacterial growth in drinking water. Applied and Environmental Microbiology, 63(8), 3242-3245.

46. Miltner, R. J., Summers, R. S., \& Wang, J. Z. (1995). Biofiltration performance: part 2, effect of backwashing. Journal American Water Works Association, 87(12), 64-70.

47. Mofidi, A., (2005). Performance of large-scale biological filtration for removal of particles and biodegradable organic matter produced by ozonation. In: Proceedings of Water Quality Technology Conference and Exposition : Water knows no Boundaries, Quebec City, Quebec (e-resource)

48. Moll, D. M., Summers, R. S., Fonseca, A. C., \& Matheis, W. (1999). Impact of temperature on drinking water biofilter performance and microbial community structure. Environmental Science \& Technology, 33(14), 2377-2382.

49. Mosqueda-Jimenez, D. B., \& Huck, P. M. (2009). Effect of biofiltration as pretreatment on the fouling of nanofiltration membranes. Desalination, 245(1), 6072.

50. Olańczuk-Neyman, K., \& Bray, R. (2000). The role of physico-chemical and biological processes in manganese and ammonia nitrogen removal from groundwater. Polish Journal of Environmental Studies, 9(2), 91-96.

51. Nishijima, W., Shoto, E., \& Okada, M. (1997). Improvement of biodegradation of organic substance by addition of phosphorous in biological activated carbon. Water Science and Technology, 36(12), 251-257.

52. Nishijima, W., Kim, W. H., Shoto, E., \& Okada, M. (1998). The performance of an ozonation-biological activated carbon process under long term operation. Water Science and Technology, 38(6), 163-169.

53. Nishijima, W., Mukaidani, T., \& Okada, M. (2003). DOC removal by multi-stage ozonation-biological treatment. Water Research, 37(1), 150-154.

54. Persson, F., Heinicke, G., Uhl, W., Hedberg, T., \& Hermansson, M. (2006). Performance of Direct Biofiltration of Surface Water for Reduction of Biodegradable Organic Matter and Biofilm Formation Potential. Environmental Technology, 27(9), 1037-1045.

55. Romani, A.M., Giorgi, A., Acuna, V., \& Sabater, S. (2004). The influence of substratum type and nutrient supply on biofilm organic matter utilization in streams. Limnology and Oceanography, 49(5), 1713-1721. 
56. Rosenberg H. 1987 Phosphate transport in prokaryotes. In: Ion Transport in Prokaryotes, B.P. Rosen editors, Academic Press, Chicago, USA, pp. 85-130.

57. Sakoda, A., Wang, J., \& Suzuki, M. (1996). Microbial activity in biological activated carbon bed by pulse responses. Water Science and Technology, 34(5), 213-222.

58. Sang, J., Zhang, X., Li, L., \& Wang, Z. (2003). Improvement of organics removal by bio-ceramic filtration of raw water with addition of phosphorous. Water Research, 37(19), 4711-4718.

59. Simpson, D. R. (2008). Biofilm processes in biologically active carbon water purification. Water Research, 42(12), 2839-2848.

60. Singer, P. C. (1999). Humic substances as precursors for potentially harmful disinfection by-products. Water Science and Technology, 40(9), 25-30.

61. Sohn, J., Amy, G., \& Yoon, Y. (2007). Process-train profiles of NOM through a drinking water treatment plant. Journal American Water Works Association, 99(6), 145-153.

62. Stembal, T., Markić, M., Ribičić, N., Briški, F., \& Sipos, L. (2005). Removal of ammonia, iron and manganese from groundwaters of northern Croatia - pilot plant studies. Process Biochemistry, 40(1), 327-335.

63. Takeuchi, Y., Mochidzuki, K., Matsunobu, N., Kojima, R., Motohashi, H., \& Yoshimoto, S. (1997). Removal of organic substances from water by ozone treatment followed by biological activated carbon treatment. Water Science and Technology, 35(7), 171-178.

64. Tchobanoglous, G. \& Burton, F.L. (1991). Wastewater Engineering: Treatment Disposal and Reuse, Mc-Graw Hill, New York, USA.

65. Tchobanoglous, G., Burton, F.L., \& Stensel, H.D. (2003). Wastewater Engineering: Treatment and reuse, McGraw Hill, New York, USA

66. Thiel, P., Zappia, L., Franzmann, P., Warton, B., Alessandrino, M., Heitz, A., \& Masters, D. (2006). Activated Carbon vs Anthracite as Primary Dual Media FiltersA Pilot Plant Study. In: 9th Annual Water Industry Engineers and Operators Conference Bendigo Exhibition Centre (Vol. 5, pp. 8-14).

67. Torriani-Gorini A. (1994). The Pho regulon of Escherichia coli. In: Phosphate in microorganisms: cellular and molecular biology. Torriani-Gorini, A., Yagil, E., Silver, S., editors. Washington, DC: ASM Press. p. 1-4.

68. Uhl, W. (2000). Biofiltration processes for organic matter removal.Biotechnology Set, Second Edition, 457-478.

69. Urfer, D., \& Huck, P. M. (2001). Measurement of biomass activity in drinking water biofilters using a respirometric method. Water Research, 35(6), 1469-1477.

70. Velten, S., Boller, M., Köster, O., Helbing, J., Weilenmann, H. U., \& Hammes, F. (2011). Development of biomass in a drinking water granular active carbon (GAC) filter. Water Research, 45(19), 6347-6354. 
71. von Gunten, U., (2003). Ozonation of drinking water: Part I. Oxidation kinetics and product formation. Water Research, 37 (7), 1443-1467.

72. Wang, J. Z., Summers, R. S., \& Miltner, R. J. (1995). Biofiltration performance: part 1, relationship to biomass. Journal American Water Works Association, 87(12), 55-63.

73. Weber-Shirk, M. L., \& Dick, R. I. (1997a). Physical-chemical mechanisms in slow sand filters. Journal American Water Works Association, 89(1), 87-100.

74. Weber-Shirk, M. L., \& Dick, R. I. (1997b). Biological mechanisms in slow sand filters. Journal American Water Works Association, 89(2), 72-83.

75. Weishaar, J. L., Aiken, G. R., Bergamaschi, B. A., Fram, M. S., Fujii, R., \& Mopper, K. (2003). Evaluation of specific ultraviolet absorbance as an indicator of the chemical composition and reactivity of dissolved organic carbon. Environmental Science \& Technology, 37(20), 4702-4708.

76. Wert, E. C., Neemann, J. J., Rexing, D. J., \& Zegers, R. E. (2008). Biofiltration for removal of $\mathrm{BOM}$ and residual ammonia following control of bromate formation. Water Research, 42(1), 372-378.

77. Xin, Y. U., Xiao-jian, Z., Xiao-ling, L., Xiao-dong, Z., Xiao-dongz, Z., \& Zhansheng, W. (2003). Phosphorous limitation in biofiltration for drinking water treatment. Journal of Environmental Sciences, 15(4), 494-499.

78. Yang, J. S., Yuan, D. X., \& Weng, T. P. (2010). Pilot study of drinking water treatment with GAC, O 3/BAC and membrane processes in Kinmen Island, Taiwan. Desalination, 263(1), 271-278.

79. Yapsakli, K., \& Çeçen, F. (2010). Effect of type of granular activated carbon on DOC biodegradation in biological activated carbon filters. Process Biochemistry, 45(3), 355-362.

80. Yavich, A. A., \& Masten, S. J. (2003). Use of ozonation and FBT to control THM precursors. Journal American Water Works Association, 95(4),159-171.

81. Yavich, A. A., Lee, K. H., Chen, K. C., Pape, L., \& Masten, S. J. (2004). Evaluation of biodegradability of NOM after ozonation. Water Research, 38(12), 2839-2846.

82. Yordanov, R. V., Lamb, A. J., Melvin, M. A. L., \& Littlejohn, J. (1996). Biomass characteristics of slow sand filters receiving ozonated water. In: Advances in slow sand and alternative biological filtration. Graham, N. abd Collins, R. editors, John Wiley \& Sons, Chichester, p. 107-118. 


\section{Appendix A - Biofilter Design}

\section{Initial Height Guess}

For ease of use, our primary design restriction is that the height of the column should not exceed 4 feet $(1.22 \mathrm{~m})$. Keeping this in mind, we must design the column.

\section{$\underline{\text { Assume a surface loading rate }(\mathrm{v}) \text { of } 1.8 \mathrm{~m} / \mathrm{hr} \text { and an Empty Bed Contact Time }}$}

\section{(EBCT)}

\section{of $15 \mathrm{~min}$}

Diameter $(\mathbf{d})=50 \mathrm{~mm}$

$$
\begin{aligned}
& \operatorname{Area}(\mathbf{A})=\frac{\pi \mathrm{d}^{2}}{4}=\frac{\pi\left(50 \times 10^{-3}\right)^{2}}{4}=1.96 \times 10^{-3} \mathrm{~m}^{2} \\
& \text { Volume }(\mathbf{V})=\pi r^{2} h=\frac{\pi d^{2}}{4} \times h \\
& \mathrm{EBCT}=\frac{\mathrm{V}}{\mathrm{Q}} \\
& 15=\frac{\frac{\pi \mathrm{d}^{2}}{4} \times \mathrm{h}}{\mathrm{A} \times \mathrm{v}} \\
& 15=\frac{\frac{\pi \mathrm{g}^{\prime}}{4} \times \mathrm{h}}{\frac{\pi \mathrm{g}^{\prime}}{\mathrm{d}} \times \mathrm{v}} \\
& 15=\frac{\mathrm{h}}{\mathrm{v}} \\
& \therefore \mathrm{h}=15 \mathrm{v} \\
& =15 \mathrm{~min} \times \frac{1.8 \mathrm{~m}}{\mathrm{hr} \times 60 \frac{\mathrm{min}}{\mathrm{hr}}} \\
& \mathrm{h}=0.45 \mathrm{~m}=450 \mathrm{~mm}
\end{aligned}
$$

This height is the height of the media (GAC and sand) only. However, $450 \mathrm{~mm}$ would be too small for our purpose. Hence, for an EBCT of 15 min, a surface loading rate of 1.8 $\mathrm{m} / \mathrm{hr}$ would not be ideal.

So, let us assume a surface loading rate of $2.8 \mathrm{~m} / \mathrm{hr}$ for an EBCT of $15 \mathrm{~min}$. 


$$
\begin{aligned}
\text { EBCT } & =\frac{\mathrm{V}}{\mathrm{Q}} \\
15 & =\frac{\frac{\pi \mathrm{d}^{2}}{4} \times \mathrm{h}}{\mathrm{A} \times \mathrm{v}} \\
15 & =\frac{\frac{\pi \mathrm{d}^{f}}{4} \times \mathrm{h}}{\frac{\pi \mathrm{d}^{f}}{4} \times \mathrm{v}} \\
15 & =\frac{\mathrm{h}}{\mathrm{v}} \\
\therefore \mathrm{h} & =15 \mathrm{v} \\
\therefore \mathrm{h} & =15 \mathrm{v} \\
& =15 \mathrm{~min} \times \frac{2.8 \mathrm{~m}}{\mathrm{hr} \times 60 \frac{\mathrm{min}}{\mathrm{hr}}} \\
\mathrm{h} & =0.7 \mathrm{~m}=700 \mathrm{~mm}
\end{aligned}
$$

A height of $700 \mathrm{~mm}$ should suit our design considerations.

Underdrain Height $=15 \mathrm{~mm}$

Thus,

Total Height $=\mathrm{h}+$ Underdrain Height $=715 \mathrm{~mm}$

So a total of $700 \mathrm{~mm}$ needs to be filled by sand and GAC.

Based on literature, full scale GAC and sand heights are in the range of $0.45-0.6 \mathrm{~m} \mathrm{GAC}$ over $0.23-0.3 \mathrm{~m}$ sand. Let us take:

GAC Height $=520 \mathrm{~mm}$

Sand Height $=180 \mathrm{~mm}$

Total Media Height $=$ GAC Height + Sand Height $=700 \mathrm{~mm}$ 
The modified Ergun equation to calculate the empty bed head loss is as follows:

$h_{L}=\left[\frac{K_{v}(1-\varepsilon)^{2}}{\varepsilon^{3}} \frac{\mu v L}{\rho_{w} g(\psi d)^{2}}\right]+\left[K_{I}\left(\frac{1-\varepsilon}{\varepsilon^{3}}\right) \frac{L v^{2}}{g \psi d}\right]$

Where,

$\mathrm{h}_{\mathrm{L}}=$ Empty bed head loss $(\mathrm{m})$

$\mu=$ Viscosity of Water $(\mathrm{kg} / \mathrm{m} . \mathrm{s})$

$\rho_{\mathrm{w}}=$ Density of Water $\left(\mathrm{kg} / \mathrm{m}^{3}\right)$

$\mathrm{L}=$ Depth of Bed (m)

$\varepsilon=$ Porosity of Media

$\mathrm{d}=$ Effective Size of Media (m)

$\mathrm{g}=$ Acceleration due to gravity $=9.81 \mathrm{~m} / \mathrm{s}^{2}$

$\mathrm{v}=$ Filtration Rate $(\mathrm{m} / \mathrm{hr})$

$\psi=$ Sphericity

In order to calculate the total head loss through the filter, we must calculate the head loss for the sand layer and the GAC layer separately. The sum of these head loss values will give us the total empty bed head loss.

Assume the GAC has a porosity of 0.55 and sphericity of 0.75

GAC Specifications

\begin{tabular}{|c|c|}
\hline ES (mm) & 0.7 \\
\hline Depth $(\mathbf{m})$ & 1.5 \\
\hline Density $\left(\mathbf{k g} / \mathbf{m}^{\mathbf{3}}\right)$ & 1700 \\
\hline Porosity & 0.5 \\
\hline Sphericity & 0.78 \\
\hline
\end{tabular}


Assume the sand has a porosity of 0.4 and a sphericity of 0.95

\begin{tabular}{|c|c|} 
Sand Specifications \\
\begin{tabular}{|c|c|}
\hline ES $(\mathbf{m m})$ & 0.5 \\
\hline Depth $(\mathbf{m})$ & 0.3 \\
\hline Density $\left(\mathbf{k g} / \mathbf{m}^{\mathbf{3}}\right)$ & 2650 \\
\hline Porosity & 0.42 \\
\hline Sphericity & 0.95 \\
\hline
\end{tabular}
\end{tabular}

Assume $K_{V}=150$ and $K_{I}=1.75$

\section{Calculations for GAC Head Loss}

Let us calculate the first term of equation 1

Using the data from the above tables, for a filtration rate of $2.8 \mathrm{~m} / \mathrm{hr}$ and a temperature of $15^{\circ} \mathrm{C}$,

$$
\begin{aligned}
1^{\text {st }} \text { term } & =\frac{150 \times(1-0.55)^{2}}{(0.55)^{3}} \times \frac{1.139 \times 10^{-3} \times\left(\frac{2.8}{3600}\right) \times 0.52}{1000 \times 9.81 \times\left(0.75 \times 0.7 \times 10^{-3}\right)^{2}} \\
& =31.10 \mathrm{~mm}
\end{aligned}
$$

Similarly, we calculate the $2^{\text {nd }}$ term

$$
\begin{aligned}
2^{\text {nd }} \text { term } & =\frac{1.75 \times(1-0.55)}{(0.55)^{3}} \times \frac{0.52 \times\left(\frac{2.8}{3600}\right)^{2}}{9.81 \times 0.75 \times\left(0.7 \times 10^{-3}\right)} \\
& =0.289 \mathrm{~mm} \\
\Rightarrow h_{L, G A C} & =31.10+0.289 \\
\therefore h_{L, G A C} & =31.39 \mathrm{~mm}
\end{aligned}
$$

\section{Calculation for Sand Head Loss}

Using the data from the above tables for a filtration rate of $2.8 \mathrm{~m} / \mathrm{hr}$ and a temperature of $15^{\circ} \mathrm{C}$, 


$$
\begin{aligned}
1^{\text {st }} \text { term } & =\frac{150 \times(1-0.4)^{2}}{(0.4)^{3}} \times \frac{1.139 \times 10^{-3} \times\left(\frac{0.28}{3600}\right) \times 0.18}{1000 \times 9.81 \times\left(0.95 \times 0.45 \times 10^{-3}\right)^{2}} \\
& =7.5 \mathrm{~mm}
\end{aligned}
$$

$$
\begin{aligned}
2^{\text {nd }} \text { term } & =\frac{1.75 \times(1-0.4)}{(0.4)^{3}} \times \frac{0.18 \times\left(\frac{2.8}{3600}\right)^{2}}{9.81 \times 0.95 \times\left(0.45 \times 10^{-3}\right)} \\
& =0.43 \mathrm{~mm}
\end{aligned}
$$

$\Rightarrow \mathrm{h}_{\mathrm{L}, \text { Sand }}=7.5+0.43$

$$
\therefore \mathrm{h}_{\mathrm{L}, \text { Sand }}=7.93 \mathrm{~m}
$$

Hence, the addition of equation 2 and 3 gives us the total head loss as follows:

$$
\begin{aligned}
\mathrm{h}_{\mathrm{L}, \text { Total }} & =\mathrm{h}_{\mathrm{L}, \mathrm{GAC}}+\mathrm{h}_{\mathrm{L}, \text { Sand }} \\
& =31.39+7.93 \\
\therefore \mathrm{h}_{\mathrm{L} \text { Total }} & =39.32 \mathrm{~mm}
\end{aligned}
$$

Let us allow for $300 \mathrm{~mm}$ for headloss build up.

Total column height $=$ Total height $+\mathrm{h}_{\mathrm{L} \text {, Total }}+$ Room for headloss buildup

$$
\begin{aligned}
& =700+39.32+300 \\
& =1039.32 \mathrm{~mm}
\end{aligned}
$$

This is less than 4 feet and our design criteria are hence met. 


\section{Appendix B - Total Phosphorous (TP) Data (Lab Scale)}

\begin{tabular}{|c|c|c|c|c|c|c|}
\hline & \multicolumn{2}{|c|}{$1-\mathrm{NSA}$} & \multicolumn{2}{|c|}{$2-\mathrm{NS} B$} & \multicolumn{2}{|c|}{3 - NL } \\
\hline $\begin{array}{c}\text { Days of } \\
\text { Operation }\end{array}$ & $\begin{array}{c}\text { Influent } \\
\text { TP } \\
(\mathrm{mg} / \mathrm{L})\end{array}$ & $\begin{array}{c}\text { Effluent } \\
\text { TP } \\
(\mathrm{mg} / \mathrm{L})\end{array}$ & $\begin{array}{c}\text { Influent } \\
\text { TP } \\
(\mathrm{mg} / \mathrm{L})\end{array}$ & $\begin{array}{c}\text { Effluent } \\
\text { TP } \\
(\mathrm{mg} / \mathrm{L})\end{array}$ & $\begin{array}{c}\text { Influent } \\
\text { TP } \\
(\mathrm{mg} / \mathrm{L})\end{array}$ & $\begin{array}{c}\text { Effluent } \\
\text { TP } \\
(\mathrm{mg} / \mathrm{L})\end{array}$ \\
\hline 148 & 5.87 & 6.75 & 1.70 & 1.24 & 0.13 & 0.39 \\
\hline 164 & 3.36 & 0.49 & 0.26 & 0.36 & 0.36 & 0.72 \\
\hline 170 & 0.65 & 0.82 & 0.98 & 0.59 & 0.88 & 0.26 \\
\hline 175 & 0.00 & 0.00 & 0.29 & 0.49 & 0.42 & 0.39 \\
\hline 177 & 0.91 & 0.91 & 0.62 & 1.37 & 0.88 & 0.42 \\
\hline 182 & 0.29 & 1.04 & 0.88 & 0.49 & 0.03 & 0.33 \\
\hline 184 & 0.42 & 0.88 & 2.06 & 0.03 & 0.23 & 0.59 \\
\hline 189 & 4.83 & 4.67 & 0.29 & 0.91 & 0.59 & 0.49 \\
\hline 192 & 0.52 & 0.23 & 0.62 & 0.26 & 0.52 & 0.29 \\
\hline 197 & 8.84 & 5.71 & 0.52 & 0.26 & 0.26 & 0.29 \\
\hline 202 & 2.09 & 1.96 & 0.23 & 0.13 & 0.10 & 0.23 \\
\hline 204 & 0.33 & 0.42 & 0.52 & 0.29 & 0.65 & 0.23 \\
\hline 209 & 0.23 & 0.39 & 0.33 & 0.23 & 0.16 & 0.23 \\
\hline 212 & 0.26 & 4.01 & 0.33 & 0.29 & 0.70 & 0.00 \\
\hline 260 & 0.23 & 0.03 & 0.82 & 0.26 & 0.85 & 0.10 \\
\hline 262 & 0.20 & 0.36 & 0.42 & 0.46 & 0.85 & 0.39 \\
\hline 267 & 0.46 & 1.14 & 0.72 & 0.52 & 0.52 & 0.55 \\
\hline 269 & 0.49 & 0.39 & 0.49 & 0.46 & 0.33 & 0.49 \\
\hline 274 & 0.23 & 0.21 & 0.23 & 0.24 & 0.15 & 0.16 \\
\hline
\end{tabular}




\begin{tabular}{|c|c|c|c|c|c|c|}
\hline 276 & 0.24 & 0.20 & 0.16 & 0.15 & 0.11 & 0.11 \\
\hline 281 & 0.08 & 0.13 & 0.18 & 0.11 & 0.15 & 0.03 \\
\hline 283 & 0.38 & 0.18 & 0.16 & 0.16 & 0.44 & 0.13 \\
\hline
\end{tabular}


Appendix C - Potassium Data (Lab Scale)

\begin{tabular}{|c|c|c|}
\hline $\begin{array}{c}\text { Days of } \\
\text { Operation }\end{array}$ & Influent (mg/L) & Effluent $(\mathrm{mg} / \mathrm{L})$ \\
\hline 262 & 1 & 0.8 \\
\hline 267 & 2.8 & 1.2 \\
\hline 269 & 0.9 & 0.8 \\
\hline 274 & 4.6 & 0.9 \\
\hline 276 & 3.2 & 3 \\
\hline 281 & 0.8 & 0.8 \\
\hline 283 & 0.9 & 0.8 \\
\hline 289 & 4.3 & 4.4 \\
\hline 296 & 1.7 & 2.6 \\
\hline 297 & 1.2 & 0.2 \\
\hline 303 & 4.2 & 1.6 \\
\hline 308 & 4 & 2.6 \\
\hline 309 & 3.9 & 3.5 \\
\hline 318 & 1 & 1.3 \\
\hline
\end{tabular}




\section{Appendix D - t-test Data}

t-test for \%DOC removals over Phase $2(n=36)$

\begin{tabular}{|c|c|c|c|c|}
\hline $\begin{array}{c}\text { Nutrient } \\
\text { Condition }\end{array}$ & $\begin{array}{c}\text { Average \%DOC } \\
\text { Removal } \pm \text { SD }\end{array}$ & p-Value & t Stat & $\begin{array}{c}\text { t Critical } \\
\text { two tail }\end{array}$ \\
\hline 1 - NS A & $32.2 \pm 10.9$ & 0.038 & 1.79 & 1.99 \\
\cline { 1 - 2 } 2 - NS B & $27.5 \pm 11.4$ & & & \\
\hline 1 - NS A & $32.2 \pm 10.9$ & 0.0001 & 3.85 & 1.99 \\
\hline 3 - NL & $22.9 \pm 9.5$ & & & \\
\hline 2 - NS B & $27.5 \pm 11.4$ & 0.034 & 1.86 & 1.99 \\
\hline $3-$ NL & $22.9 \pm 9.6$ & & & \\
\hline
\end{tabular}




\section{Appendix E - C/N Balances}

\begin{tabular}{|c|c|c|c|c|c|c|c|c|c|}
\hline \multicolumn{10}{|c|}{ DOC (mg/L) } \\
\hline \multirow{2}{*}{$\begin{array}{c}\text { Days of } \\
\text { Operation }\end{array}$} & \multicolumn{3}{|c|}{ NSA } & \multicolumn{3}{|c|}{ NS B } & \multicolumn{3}{|c|}{ NL } \\
\hline & Influent & Effluent & Uptake & Influent & Effluent & Uptake & Influent & Effluent & Uptake \\
\hline 141 & 12.34 & 9.21 & 3.14 & 12.64 & 9.19 & 3.45 & 12.43 & 10.08 & 2.35 \\
\hline 148 & 10.74 & 6.79 & 3.95 & 12.84 & 8.52 & 4.32 & 10.19 & 8.90 & 1.30 \\
\hline 167 & 14.45 & 10.18 & 4.27 & 19.68 & 9.83 & 9.85 & 19.84 & 10.98 & 8.86 \\
\hline 170 & 14.78 & 9.72 & 5.06 & 13.73 & 8.77 & 4.96 & 13.58 & 10.26 & 3.32 \\
\hline 174 & 8.09 & 7.26 & 0.83 & 11.16 & 9.47 & 1.69 & 11.09 & 9.18 & 1.91 \\
\hline 176 & 10.91 & 7.86 & 3.05 & 11.55 & 8.05 & 3.50 & 11.50 & 8.76 & 2.74 \\
\hline 181 & 11.51 & 7.61 & 3.90 & 11.78 & 7.59 & 4.19 & 11.66 & 8.15 & 3.51 \\
\hline 183 & 11.63 & 8.00 & 3.63 & 11.99 & 8.15 & 3.84 & 12.00 & 8.45 & 3.55 \\
\hline 185 & 11.84 & 8.21 & 3.63 & 12.11 & 7.65 & 4.46 & 12.48 & 8.40 & 4.08 \\
\hline 192 & 12.34 & 7.59 & 4.75 & 11.55 & 7.41 & 4.14 & 11.62 & 8.08 & 3.54 \\
\hline 196 & 12.27 & 8.49 & 3.78 & 12.27 & 7.64 & 4.63 & 12.35 & 8.93 & 3.43 \\
\hline 202 & 12.96 & 8.01 & 4.95 & 12.47 & 7.99 & 4.48 & 11.92 & 9.84 & 2.08 \\
\hline 204 & 11.49 & 7.55 & 3.94 & 8.74 & 7.85 & 0.90 & 12.01 & 9.75 & 2.26 \\
\hline 209 & 11.89 & 8.77 & 3.12 & 10.82 & 8.47 & 2.36 & 12.06 & 9.84 & 2.22 \\
\hline 217 & 8.55 & 7.56 & 0.99 & 8.67 & 7.80 & 0.87 & 11.67 & 7.93 & 3.75 \\
\hline 260 & 11.32 & 8.18 & 3.14 & 11.13 & 8.24 & 2.89 & 11.27 & 9.38 & 1.89 \\
\hline 262 & 10.93 & 7.66 & 3.27 & 11.00 & 7.92 & 3.08 & 11.14 & 8.89 & 2.25 \\
\hline 267 & 11.87 & 8.43 & 3.44 & 12.90 & 7.24 & 5.66 & 12.98 & 11.02 & 1.96 \\
\hline 269 & 12.33 & 7.91 & 4.42 & 11.95 & 7.57 & 4.38 & 12.66 & 9.70 & 2.96 \\
\hline 274 & 11.13 & 8.39 & 2.74 & 10.91 & 6.98 & 3.93 & 9.29 & 4.18 & 5.11 \\
\hline
\end{tabular}




\begin{tabular}{|c|c|c|c|c|c|c|c|c|c|}
\hline 276 & 9.51 & 3.81 & 5.70 & 9.46 & 7.84 & 1.62 & 11.30 & 9.71 & 1.59 \\
\hline 296 & 9.59 & 6.35 & 3.24 & 9.91 & 6.50 & 3.41 & 8.84 & 4.94 & 3.90 \\
\hline 297 & 7.86 & 2.47 & 5.39 & 7.04 & 4.66 & 2.38 & 7.75 & 5.20 & 2.55 \\
\hline 308 & 9.65 & 6.56 & 3.09 & 9.38 & 8.39 & 0.99 & 9.22 & 6.65 & 2.57 \\
\hline 309 & 10.32 & 6.95 & 3.37 & 9.15 & 6.58 & 2.57 & 9.36 & 8.61 & 0.75 \\
\hline 318 & 8.83 & 6.07 & 2.76 & 8.73 & 6.36 & 2.37 & 8.99 & 7.59 & 1.40 \\
\hline Average & 11.12 & 7.52 & 3.60 & 11.29 & 7.79 & 3.50 & 11.51 & 8.59 & 2.92 \\
\hline
\end{tabular}

\begin{tabular}{|c|c|c|c|c|c|c|c|c|c|}
\hline \multicolumn{10}{|c|}{ TN (mg/L) } \\
\hline \multirow{2}{*}{$\begin{array}{c}\text { Days of } \\
\text { Operation }\end{array}$} & \multicolumn{3}{|c|}{ NS A } & \multicolumn{3}{|c|}{ NS B } & \multicolumn{3}{|c|}{ NL } \\
\hline & Influent & Effluent & Uptake & Influent & Effluent & Uptake & Influent & Effluent & Uptake \\
\hline 141 & 1.078 & 0.870 & 0.208 & 0.577 & 0.724 & -0.147 & 0.469 & 0.423 & 0.046 \\
\hline 148 & 1.369 & 1.215 & 0.154 & 1.421 & 0.820 & 0.601 & 0.501 & 0.412 & 0.089 \\
\hline 167 & 0.490 & 0.122 & 0.368 & 0.875 & 0.279 & 0.596 & 0.548 & 0.215 & 0.333 \\
\hline 170 & 0.517 & 0.261 & 0.256 & 0.584 & 0.731 & -0.147 & 0.531 & 0.218 & 0.313 \\
\hline 174 & 0.429 & 0.361 & 0.068 & 0.418 & 0.336 & 0.082 & 0.433 & 0.333 & 0.101 \\
\hline 176 & 0.469 & 0.354 & 0.115 & 0.417 & 0.430 & -0.013 & 0.420 & 0.360 & 0.059 \\
\hline 181 & 0.499 & 0.533 & -0.034 & 0.617 & 0.542 & 0.075 & 0.516 & 0.402 & 0.114 \\
\hline 183 & 0.959 & 0.851 & 0.108 & 0.608 & 0.457 & 0.150 & 0.442 & 0.380 & 0.062 \\
\hline 185 & 0.552 & 0.408 & 0.144 & 0.910 & 0.707 & 0.203 & 0.498 & 0.433 & 0.065 \\
\hline 192 & 0.377 & 0.300 & $\begin{array}{l}0.077 \\
\end{array}$ & 0.395 & 0.425 & -0.030 & 0.407 & 0.389 & 0.018 \\
\hline 196 & 0.454 & 0.289 & 0.165 & 0.455 & 0.302 & 0.153 & 0.404 & 0.304 & 0.099 \\
\hline 202 & 0.624 & 0.586 & 0.037 & 0.402 & 0.373 & 0.029 & 0.393 & 0.388 & 0.005 \\
\hline 204 & 0.448 & 0.346 & 0.102 & 0.395 & 0.310 & 0.085 & 0.365 & 0.393 & -0.028 \\
\hline
\end{tabular}




\begin{tabular}{|c|c|c|c|c|c|c|c|c|c|}
\hline 209 & 0.440 & 0.320 & 0.120 & 0.487 & 0.324 & 0.163 & 0.444 & 0.353 & 0.091 \\
\hline 217 & 0.417 & 0.402 & 0.015 & 0.493 & 0.364 & 0.130 & 0.425 & 0.365 & 0.061 \\
\hline 260 & 0.693 & 0.741 & -0.047 & 0.636 & 0.516 & 0.120 & 0.742 & 0.642 & 0.100 \\
\hline 262 & 0.652 & 0.709 & -0.057 & 0.654 & 0.583 & 0.071 & 0.684 & 0.604 & 0.081 \\
\hline 267 & 0.627 & 0.785 & -0.158 & 1.123 & 0.810 & 0.313 & 0.683 & 0.704 & -0.022 \\
\hline 269 & 0.612 & 0.632 & -0.020 & 1.050 & 0.814 & 0.236 & 0.662 & 0.686 & -0.024 \\
\hline 274 & 1.270 & 1.57 & -0.300 & 0.790 & 0.67 & 0.120 & 0.670 & 0.65 & 0.020 \\
\hline 276 & 1.2 & 0.937 & 0.263 & 0.94 & 0.71 & 0.230 & 0.7 & 0.74 & -0.040 \\
\hline 296 & 1.36 & 0.51 & 0.850 & 1.18 & 0.47 & 0.710 & 0.87 & 0.84 & 0.030 \\
\hline 297 & 0.82 & 0.6 & 0.220 & 0.78 & 0.61 & 0.170 & 0.81 & 0.69 & 0.120 \\
\hline 308 & 1.21 & 0.98 & 0.230 & 1.08 & 1.03 & 0.050 & 0.81 & 0.72 & 0.090 \\
\hline 309 & 0.84 & 0.99 & -0.150 & 1.12 & 0.66 & 0.460 & 0.71 & 0.49 & 0.220 \\
\hline 318 & 0.74 & 0.69 & 0.050 & 0.81 & 0.65 & 0.160 & 0.71 & 0.65 & 0.060 \\
\hline Average & 0.736 & 0.629 & 0.107 & 0.739 & 0.563 & 0.176 & 0.571 & 0.492 & 0.079 \\
\hline
\end{tabular}




\begin{tabular}{|c|c|c|c|c|c|c|c|c|}
\hline \multicolumn{9}{|c|}{ C/N Based on Uptake } \\
\hline \multicolumn{3}{|c|}{ NS A Uptake } & \multicolumn{3}{|c|}{ NS B Uptake } & \multicolumn{3}{|c|}{ NL Uptake } \\
\hline $\begin{array}{c}\text { DOC } \\
(\mathrm{mg} / \mathrm{L})\end{array}$ & $\begin{array}{c}\text { TN } \\
(\mathrm{mg} / \mathrm{L})\end{array}$ & $\mathrm{C} / \mathrm{N}$ & $\begin{array}{c}\text { DOC } \\
(\mathrm{mg} / \mathrm{L})\end{array}$ & $\begin{array}{c}\mathrm{TN} \\
(\mathrm{mg} / \mathrm{L})\end{array}$ & $\mathrm{C} / \mathrm{N}$ & $\begin{array}{c}\text { DOC } \\
(\mathrm{mg} / \mathrm{L})\end{array}$ & $\begin{array}{c}\mathrm{TN} \\
(\mathrm{mg} / \mathrm{L})\end{array}$ & $\mathbf{C} / \mathbf{N}$ \\
\hline 3.14 & 0.21 & 15.07 & 3.45 & -0.15 & -23.52 & 2.35 & 0.05 & 50.87 \\
\hline 3.95 & 0.15 & 25.63 & 4.32 & 0.60 & 7.18 & 1.30 & 0.09 & 14.48 \\
\hline 4.27 & 0.37 & 11.61 & 9.85 & 0.60 & 16.51 & 8.86 & 0.33 & 26.58 \\
\hline 5.06 & 0.26 & 19.73 & 4.96 & -0.15 & -33.72 & 3.32 & 0.31 & 10.59 \\
\hline 0.83 & 0.07 & 12.14 & 1.69 & 0.08 & 20.51 & 1.91 & 0.10 & 18.88 \\
\hline 3.05 & 0.11 & 26.54 & 3.50 & -0.01 & -270.60 & 2.74 & 0.06 & 46.05 \\
\hline 3.90 & -0.03 & -114.7 & 4.19 & 0.08 & 55.58 & 3.51 & 0.11 & 30.84 \\
\hline 3.63 & 0.11 & 33.76 & 3.84 & 0.15 & 25.53 & 3.55 & 0.06 & 56.76 \\
\hline 3.63 & 0.14 & 25.12 & 4.46 & 0.20 & 21.98 & 4.08 & 0.06 & 63.01 \\
\hline 4.75 & 0.08 & 61.80 & 4.14 & -0.03 & -139.87 & 3.54 & 0.02 & 195.49 \\
\hline 3.78 & 0.16 & 22.93 & 4.63 & 0.15 & 30.26 & 3.43 & 0.10 & 34.45 \\
\hline 4.95 & 0.04 & 132.6 & 4.48 & 0.03 & 155.25 & 2.08 & 0.00 & 432.96 \\
\hline 3.94 & 0.10 & 38.49 & 0.90 & 0.09 & 10.48 & 2.26 & -0.03 & -80.29 \\
\hline 3.12 & 0.12 & 25.90 & 2.36 & 0.16 & 14.48 & 2.22 & 0.09 & 24.37 \\
\hline 0.99 & 0.02 & 65.34 & 0.87 & 0.13 & 6.71 & 3.75 & 0.06 & 61.85 \\
\hline 3.14 & -0.05 & -66.38 & 2.89 & 0.12 & 23.99 & 1.89 & 0.10 & 18.87 \\
\hline 3.27 & -0.06 & -57.09 & 3.08 & 0.07 & 43.18 & 2.25 & 0.08 & 27.93 \\
\hline 3.44 & -0.16 & -21.80 & 5.66 & 0.31 & 18.10 & 1.96 & -0.02 & -89.89 \\
\hline 4.42 & -0.02 & -217.46 & 4.38 & 0.24 & 18.55 & 2.96 & -0.02 & -123.23 \\
\hline 2.74 & -0.30 & -9.13 & 3.93 & 0.12 & 32.75 & 5.11 & 0.02 & 255.50 \\
\hline
\end{tabular}




\begin{tabular}{|c|c|c|c|c|c|c|c|c|c|}
\hline & 5.70 & 0.26 & 21.67 & 1.62 & 0.23 & 7.04 & 1.59 & -0.04 & -39.75 \\
\hline & 3.24 & 0.85 & 3.81 & 3.41 & 0.71 & 4.80 & 3.90 & 0.03 & 130.00 \\
\hline & 5.39 & 0.22 & 24.50 & 2.38 & 0.17 & 14.00 & 2.55 & 0.12 & 21.25 \\
\hline & 3.09 & 0.23 & 13.43 & 0.99 & 0.05 & 19.80 & 2.57 & 0.09 & 28.56 \\
\hline & 3.37 & -0.15 & -22.47 & 2.57 & 0.46 & 5.59 & 0.75 & 0.22 & 3.41 \\
\hline & 2.76 & 0.05 & 55.20 & 2.37 & 0.16 & 14.81 & 1.40 & 0.06 & 23.33 \\
\hline Average & 3.66 & 0.18 & 20.80 & 3.40 & 0.22 & 15.25 & 3.05 & 0.10 & 30.77 \\
\hline
\end{tabular}

\begin{tabular}{|c|c|c|c|}
\hline \multicolumn{5}{|c|}{ Measured Values (averaged over Phase 2, 3) } \\
\hline & NS A & NS B & NL \\
\hline Average Influent DOC (mg/L) & 11.12 & 11.29 & 11.51 \\
\hline Average Influent TN (mg/L) & 0.74 & 0.74 & 0.57 \\
\hline Average Influent C/N & 15.10 & 15.27 & 20.15 \\
\hline Average Effluent DOC (mg/L) & 7.52 & 7.79 & 8.59 \\
\hline Average Effluent TN (mg/L) & 0.63 & 0.56 & 0.49 \\
\hline Average Effluent C/N & 11.95 & 13.83 & 17.47 \\
\hline
\end{tabular}

Theoretical Values (Based on mass Balance, dosing)

\begin{tabular}{|c|c|c|c|}
\hline & NS A & NS B & NL \\
\hline Influent DOC (mg/L) & 11.10 & 11.10 & 11.10 \\
\hline Influent TN (mg/L) & 2.20 & 1.10 & 0.29 \\
\hline Influent C/N & 5.0 & 10.09 & 38.28 \\
\hline
\end{tabular}

